\author{
UNIVERSIDADE DE SÃO PAULO \\ FACULDADE DE FILOSOFIA, LETRAS E CIÊNCIAS HUMANAS \\ DEPARTAMENTO DE GEOGRAFIA \\ PROGRAMA DE PÓS-GRADUAÇÃO EM GEOGRAFIA HUMANA
}

\title{
GRANJA VIANA: A PRODUÇÃO (IDEO)LÓGICA DO ESPAÇO
}

Ana Cristina Trivelato

Orientadora: Profa. Dra. Glória da Anunciação Alves

São Paulo 


\author{
UNIVERSIDADE DE SÃO PAULO \\ FACULDADE DE FILOSOFIA, LETRAS E CIÊNCIAS HUMANAS \\ DEPARTAMENTO DE GEOGRAFIA \\ PROGRAMA DE PÓS-GRADUAÇÃO EM GEOGRAFIA HUMANA
}

\title{
GRANJA VIANA: A PRODUÇÃO (IDEO)LÓGICA DO ESPAÇO
}

Dissertação apresentada ao Programa de Pós-

Graduação em Geografia Humana, do

Departamento de Geografia da Faculdade de

Filosofia, Letras e Ciências Humanas da

Universidade de São Paulo, para obtenção do

Título de Mestre em Geografia.

Ana Cristina Trivelato

Orientadora: Profa. Dra. Glória da Anunciação Alves

São Paulo 


\title{
RESUMO
}

\section{GRANJA VIANA: A PRODUÇÃO (IDEO)LÓGICA DO ESPAÇO}

\begin{abstract}
O trabalho aqui proposto perseguiu a compreensão e a explicação da constituição da produção espacial num dado fragmento da grande metrópole paulistana, a região da Granja Viana pertencente ao município de Cotia. Os espaços foram sendo privatizados e produzidos de forma hierarquizada e os meios que influenciaram e ainda influenciam na constituição e manutenção de lugares nobres e periféricos dentro de uma mesma região estão estritamente ligados a uma estratégia de (re)produção do capital por meio do mercado imobiliário.
\end{abstract}

A Granja Viana "vendida" carrega consigo um ideal de qualidade de vida associado ao requinte e segurança que estabelece uma identidade aos empreendimentos oferecidos. Porém existe algo a mais no espaço e que nem sempre é aparente: trata-se da diversidade e dos conflitos. Nesta região o velho e o novo, assim como a abundância e a raridade se mantêm num permanente fazer e refazer de um espaço que não é homogêneo.

\section{PALAVRAS-CHAVE}

Espaço, Sociedade, Hierarquização, Transformação e Capital. 


\section{ABSTRACT \\ GRANJA VIANA: (IDEO)LOGICAL PRODUCTION OF SPACE}

This work attempted to make understandable and to explain how a production of space is established in a small portion of a big city. The object of this study is Granja Viana area located in Cotia city, near São Paulo.

This area has been privatized and developed in a hierarchical way, and the means that influenced and still influence the building up and the maintenance of noble places and peripheries in a same region are strictly related to a capital grow strategy thru the real estate market.

The "sold" Granja Viana carries an ideal of quality life associated to refinement and security, which creates an identity to the offered enterprises.

But there is something else in this space, which is not always evident that is diversities and conflicts. Old and new in this region as well as abundance and scarcity, maintain an invariable make and remake of a heterogeneous space.

\section{KEYWORDS}

Space, Society, Hierarchical, Transformation and Capital. 
Ao meu pai Vagner e À minha mãe Rosa. 


\section{AGRADECIMENTOS}

Em primeiro lugar, não poderia ser diferente, agradeço a Deus pela minha vida e pelas oportunidades que muitas vezes surgem de forma inexplicáveis.

À minha orientadora, sempre professora Glória, que foi a mão amiga que vem me conduzindo neste maravilhoso caminho acadêmico, já há alguns anos, de forma incansável.

Ao meu pai que chorou comigo na proficiência e à minha mãe que sustentou o meu mestrado com tanto esmero e dedicação.

Às minhas irmãs de sangue e alma sempre companheiras, à Cecília pelo financiamento e à Karine por me "emprestar" os amigos.

Ao Sandro, que apareceu no meio do caminho e tem me dado a oportunidade de viver algo novo.

Ao Bruno pelo suporte técnico, quantas continhas para determinar as escalas.

Ao meu tio Valdir, por me instigar a querer compreender um pouco melhor a realidade e à $\mathrm{D}$. Zeni pelos favores "britanicamente" atendidos.

Aos meus tios e primos, que apostaram sempre em mim, à minha afilhada Maithê em especial.

Aos amigos de colóquios Adailton, Emerson, Kleber, Maria Ângela, Nancy, Nedir, Sandrinha e ao Wilson, pelos momentos inestimáveis.

Aos amigos que direta ou indiretamente ajudaram na concretização deste trabalho durante todos esses anos, mas em especial à Nádia, à Raqueline, ao Maurício e ao Dr.Sérgio Guisard.

Aos professores que tive contato nesta Universidade, que mundo maravilhoso é este do conhecimento.

Às pessoas comuns que me ajudaram na pesquisa de campo a compor o trabalho apresentado. 


\section{ÍNDICE}

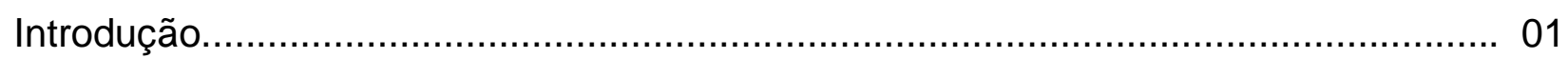

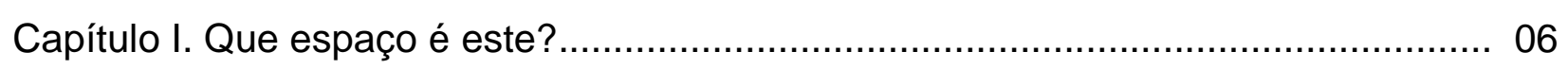

Capítulo II. Tem briga na Granja: quem canta de galo? ...................................... 33

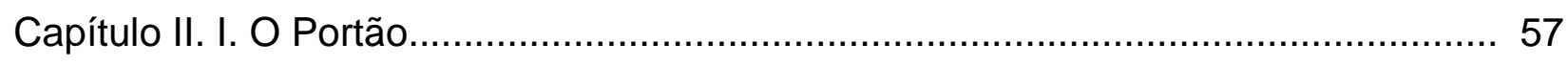

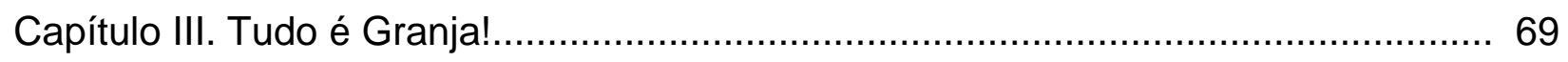

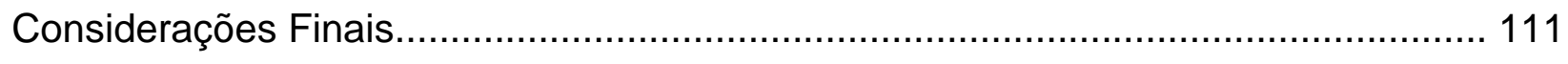

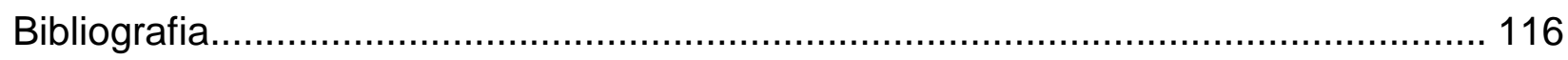




\section{Introdução}

A história com suas continuidades, descontinuidades e superações, tem momentos que são apreendidos no espaço que, constituído por fragmentos, são compostos por elementos dados pela história. Compreendendo a unicidade desses dois elementos - tempo e espaço - é que percebemos melhor a dimensão dada pelo momento presente, nos parece evidente que para melhor entendermos a produção de nossa sociedade, as regras que tendem a nos regir, a ideologia a qual estamos imbuídos, faz-se necessário voltarmos o nosso olhar ao espaço enquanto recorte da construção social constituído numa escala temporal.

Em meio a tantas dimensões difusas, percebemos nos fragmentos espaciais as particularidades que compõem o todo, mas este último encontra-se, muitas vezes, em contraposição às suas particularidades. Fragilizado pela força da fragmentação os espaços vão assumindo cada vez mais a aparência do igual, do homogêneo, do uniforme e isso nos parece ser possível por causa do processo da reprodução espacial, que também cria representações e símbolos espaço-sociais que passam a fazer parte da lógica da vida moderna. Os espaços iluminados ${ }^{1}$ tendem à igualdade, enquanto as relações que se dão nestes mesmos espaços vão cada vez mais tendendo às diferenças.

Entendendo o espaço como meio e resultado da ação social e tomando o processo de acumulação como atividade supra da sociedade capitalista, e ainda considerando que o modo de vida urbano escapou aos domínios da cidade e generalizou-se, buscamos, por meio da análise de uma região do município de Cotia/SP, a Granja Viana, entender um pouco melhor o processo de (re) produção do espaço urbano.

Partimos do pressuposto de que os espaços tornados mercadorias refletem uma condição social de hierarquização, no caso de estudo uma única região de uma cidade pertencente à grande metrópole é capaz de mostrar tantas faces e tantas realidades,

${ }^{1}$ Chamamos aqui de iluminados os espaços que concentram as novas formas de produção e reprodução econômica, política e social, geralmente identificados como os espaços da modernidade. 
que há momentos em que nossa percepção parece não conseguir captar todas as relações estabelecidas neste espaço. A compreensão das formas e dos conteúdos de seus vários fragmentos possibilita, por meio da analise da parte, entender um processo mais totalizador.

O trabalho a que nos propomos procurará abordar, num primeiro momento, a região da Granja Viana. Discutiremos como nesse espaço foi realçado o valor de troca. A medida em que o mercado imobiliário investia em parte da região, trabalharemos com a construção dos discursos ideológicos que promovem o espaço, bem como os motivos que levam uma parte dos moradores da metrópole paulistana buscar na região granjeira um lugar para morar. Em seguida iremos abordar um dos fragmentos da região, a Granja nobre, que possui uma identidade muito própria, mas também plena de espaços e relações de conflitos. Nesse espaço podemos encontrar o "diferente" mesmo entre os iguais, entender a forma como o mercado influencia esta relação, o convívio e o consumo intimamente ligados na promoção de "outros espaços iguais" para as "mesmas pessoas diferentes". Num terceiro momento tentaremos a região da Granja como um todo, ou de outra forma a articulação de seus fragmentos, incluindo a Granja Viana diferente daquela mostrada nos outdoors. Assim pretendemos trabalhar com a região da abundância e da raridade, as duas ao mesmo tempo coexistindo no mesmo espaço, dividido, mas o mesmo.

Cotia está localizada à sudoeste da capital paulista - como vemos a seguir, e embora área periférica ${ }^{2}$ inscreve-se - se, por meio da Reserva Florestal do Morro Grande e da ainda existência de prática agrícola como parte da Reserva da Biosfera do Cinturão Verde da Cidade de São Paulo ${ }^{3}$ - conforme imagem abaixo, e é esta condição que dá à cidade uma posição privilegiada na relação centro-periferia. À distância de 33 km entre Cotia da capital paulistana é minimizada pela existência da rodovia Raposo

\footnotetext{
${ }^{2}$ Por tratar-se de uma cidade distante (cerca de $33 \mathrm{~km}$ ) do centro da metrópole paulista.

${ }^{3}$ Segundo o Instituto Florestal a Reserva da Biosfera do Cinturão Verde da Cidade de São Paulo é parte integrante da Reserva da Biosfera da Mata Atlântica e trata-se de uma área composta por 73 municípios que circunda uma das maiores metrópoles do mundo. No entanto a idéia de que "O Cinturão Verde que envolve a Região Metropolitana de São Paulo, é fundamental para a oferta de bens e serviços aos habitantes da metrópole, como água, clima equilibrado, lazer, alimentos, além de boas condições de habitação e saúde" (Folder do Instituto Florestal) é polêmica, ver Tese de OLIVEIRA, Ariovaldo Umbelino.
} 
Tavares que vem sofrendo melhorias e duplicações, modernizando-se para atender um fluxo automobilístico de circulação cada vez mais intenso.

Temos na cidade de Cotia uma transformação dos espaços. Estes foram assumindo diferentes funções com a formação de diversos centros de consumo, cada qual atendendo uma demanda diferente em cada período histórico da cidade e, conforme focaremos neste trabalho, uma única região do município acabou, aparentemente, ganhando "vida própria", cuja realização está muito mais voltada para a metrópole paulistana do que para si própria. Poderíamos rapidamente iniciar falando de Cotia como rota dos bandeirantes ou então dos tropeiros que iam para o sul e que usavam o que hoje é centro histórico/tradicional com a finalidade principal de pouso. Depois teríamos com a chegada da colônia japonesa uma Cotia hortifrutigranjeira, e posteriormente, uma Cotia industrial e residencial, duas tendências econômicas que ocorreram concomitantemente e que acabaram originando um grande expoente cotiano, a Granja Viana, que hoje assumi uma importância muito grande na economia do município, passando a atrair investimentos públicos e privados em infra-estrutura, comércio e serviço dos mais diversos. 
Dentro da região da Granja Viana, o que prevaleceu até hoje foi o mercado imobiliário voltado para uma classe média e alta paulistana. A questão ambiental acabou por servir a uma estratégia de marketing que conseguiu super valorizar os espaços que ainda possuem atrativos "naturais", como uma reserva de Mata Atlântica, por exemplo. Esses mesmos espaços passam gradativamente a terem minimizados seu valor de uso em detrimento de seu valor de troca, igualmente como acontece com o espaço urbano, como nos mostra LEFEBVRE (1999:144).

A Granja Viana é produzida por uma gama de relações que permitem um quadro bastante complexo e intrigante. Embora a Granja Viana tenha passado por diferentes tendências no uso do seu espaço, foi ficando cada vez mais claro que a Granja Viana deveria ser "consumida" por um determinado tipo de população. De região originalmente ocupada por chácaras e sítios de final de semana para os paulistanos, até a sua gradativa transformação em área industrial e concomitantemente em ascendente região para moradia (de alto e médio padrão) as transformações espaciais deram novas características para a região. Nessas transformações temos que chamar a atenção para as estratégias do mercado imobiliário, bem como a institucionalização do "público" e o investimento do "privado" na região, que promoveram uma interferência no modo de vida da população a medida em que o espaço foi sendo constituído e direcionando para uma determinada finalidade. Buscamos entender na relação desta população com o seu entorno, o efeito da ação ideológica e mercadológica do espaço, o uso do poder público na promoção de "lugares" hierarquizados.

A fragmentação espacial e a sua condição enquanto mercadoria na produção desigual do espaço é um movimento que poderia ser apreendido em qualquer lugar, contudo temos duas razões preponderantes para a escolha de Cotia como o espaço para este estudo: o primeiro diz respeito ao breve período de tempo em que muitas mudanças espaciais ocorreram na cidade, e o segundo deve-se ao fato de que o município é o lugar de nossa convivência, portanto há muito tempo estamos acompanhando não só as mudanças estruturais e funcionais do espaço como os discursos que vêm validando estas mudanças. 
Há uma evidente necessidade em termos de acesso às particularidades e a historicidade da cidade, que nos serão necessárias para que nos ajudem a entender melhor as transformações espaciais, e para isso fez-se necessário a coleta de dados por meio de arquivos de jornais e revistas locais, de documentos contidos nos diferentes órgãos da prefeitura como Plano Diretor, Lei de Zoneamento, Parcelamento e Uso do Solo, Doação de Mudas, Projeções Turísticas, Projeto de Lei, bem como dados do IBGE.

Pretendemos com isso reunir informações suficientes para que possamos compreender um pouco melhor as relações entre o espaço e a sociedade, tendo no mercado, no seu movimento de reprodução e acumulação, a mediação desta relação.

Traçada as linhas que irão nos nortear esperamos, com o trabalho que será apresentado a seguir, colaborar com a geografia na construção de uma análise explicativa da sociedade contemporânea a partir de nosso estudo de caso. 


\section{Capítulo I. Que espaço é este?}

Buscar a explicação para a produção espacial é uma tarefa complexa se considerarmos a multiplicidade de elementos que coexistem e participam das relações de produção do espaço. Segundo CARLOS (2003:31) "o espaço geográfico não é estático, mas uma produção contínua, um 'fazer incessante'. É um produto histórico que se originou historicamente, não é um palco das atividades humanas...", existe uma relação intrínseca entre o espaço e a sociedade, os dois influenciam mutuamente na sua transformação.

Ainda na perspectiva de que o espaço e a sociedade tem seu processo produtivo e de transformação intrínseco, um influenciando o outro, procuramos analisar neste trabalho a produção do espaço citadino, onde "...a cidade seria a obra perpétua dos seus habitantes, o que contraria a idéia de receptáculo passivo da produção e das políticas de planejamento" (CARLOS, 2003:33). Se existe a produção/reprodução espacial é porque existem agentes que o estão produzindo, e estes só o produz porque o próprio espaço também participa na transformação social.

A cidade é, por excelência, o espaço de convivência, das trocas de relações sociais em suas variadas escalas. Assim, o uso do espaço por meio do emprego do tempo e a materialização do tempo no espaço também ocorre influenciada pela escala do vivido, enquanto prática da vida cotidiana. Hoje, em um mundo em que há, tendencialmente, a prioridade e ênfase aos processos produtivos concorrenciais em escala global, a cidade passa a ser pensada quase que exclusivamente, principalmente quando se remete a administração, planejamento e ações de reprodução espacial da cidade, apenas do ponto de vista racional, praticamente eliminando-se a dimensão da vida cotidiana de seus cidadãos. Deste modo, temos espaços em que predominam a lógica da circulação de produtos e veículos, priorizando a reprodução do capital que se materializa no espaço, este entendido como mercadoria e a quase negação do uso do espaço, já que há prioridade é dada à troca. A cidade hoje é um espaço de troca, onde tudo tem que ser produtivo e mercantil.

O sentido da cidade, o seu espaço, a vida aí existente, faz-se na multiplicidade e na diversidade dos ritmos, formas, caminhos, encontros e significados traduzidos pelas 
suas muitas partes enquanto fração de um único todo, assim como as várias faces de um único prisma ou ainda a constituição de um todo com partes distintas como um caleidoscópio.

Há uma evidente tentativa em produzir o espaço da sociedade urbana, segundo uma racionalidade capitalista, que produz um movimento infindável de necessidades e supressões, fazer e desfazer, produzir e consumir, substituir e manter, construir e desconstruir. A necessidade de (re) produção do capital faz com que as mudanças espaciais sejam constantes, a concentração ou a expansão da mancha urbana no espaço atribuído pela mais valia por meio da propriedade é a variável que faz surgir a abundância e a escassez, inclusive espaciais.

Nos faz imprescindível reforçar neste momento a idéia de que a racionalidade econômica empregada atualmente desconhece as fronteiras econômicas. Aparentemente tudo está contido no capital, tudo é transformado em mercadoria e a acumulação passa a ser "via de mão dupla" na sociedade em todas as suas relações. O mesmo sistema que garante a (re) produção do capital, que vem transformando a natureza há séculos faz o mesmo com a sociedade, ou seja, a transforma também por meio do seu espaço. Devemos aqui lembrar que as cidades são hoje, na sociedade brasileira, o lugar de maior concentração populacional e que a cidade, como nos diz CARLOS (2003:26) “... é um modo de viver, pensar, mas também sentir. O modo de vida urbano produz idéias, comportamentos, valores, conhecimentos, formas de lazer, e também uma cultura". Hoje, o que percebemos é que a cidade, enquanto maior expressão do modo de vida urbano, vem sendo tomada com grande força pela ação mercado, assim como toda sociedade.

Entender a cidade e o modo de viver urbano é uma tarefa que exige muito do pesquisador, pois existem elementos variados e ambíguos que vão se fundido o que faz com que a identidade da sociedade metropolitana venha sendo construída também de acordo com a vivência cotidiana em que cada vez mais se difunde e generaliza, por meio das políticas públicas e dos mass mídia, entre outros, idéias que priorizam a racionalidade econômica. Ainda que isso seja, a nosso ver, uma característica atual da sociedade urbana, também entendemos que a cidade pode ser vista enquanto uma 
"Torre de Babel", ou seja, que apresenta a possibilidade de entendê-la por sua diversidade citatina, cabendo ao pesquisador a tarefa de eleger determinados aspectos que possam melhor iluminar a busca em explicar e entender a (re) produção espacial.

As cidades vão tendo seus centros definidos de acordo com as atividades exercidas no decorrer histórico, e a expansão desses centros é um movimento inevitável, as centralidades vão surgindo e redefinindo não somente os espaços como o modo de viver, afinal "...O centro só pode, pois, dispersar-se em centralidades parciais e móveis (policentralidade), cujas relações concretas determinam-se conjunturalmente...". (LEFEBVRE, 2002:93)

Num curto espaço de tempo acontece um fato que nos é difícil de determinar a ação "causa-consequência", ou seja, serão as centralidades que vão se multiplicando e preenchendo os espaços do seu entorno e originando as centralidades múltiplas (das tradicionais as especializadas) como as de bairro, a antiga, a nova, a residencial, a comercial, a gastronômica, a financeira, a cultural, a de lazer, enfim e vão tornando esses espaços passagens obrigatórias de um número cada vez maior de pessoas que procuram as finalidades do local.

Tudo se tornou relativo na cidade, os centros, as centralidades e a periferia, ora distante, ora imediato, o espaço vai sendo produzido e reproduzido com um movimento incessante e inerente ao modo de viver cosmopolita. As pessoas que moram em grandes centros metropolitano como é a cidade de São Paulo, estão acostumadas com esse "faz e refaz" espacial.

É fato, a cidade vai sendo redimensionada, é a concentração de prédios, atividades e pessoas de um lado e do outro a (dês) concentração econômica e industrial, as políticas e a engenharia do outro, tudo na cidade parece ter uma enorme aptidão para o moderno, as construções, os monumentos, todos os símbolos metropolitanos mudam não só fisicamente como de lugar também.

A busca por novos espaços, essa é a frase que define muito bem o processo de produção e reprodução espacial, a lógica capitalista de acumulação faz com que uma cidade, como a de São Paulo, uma cidade considerada global/mundial (SASSEN, 1998), onde a circulação de mercadorias e decisões multiplica o potencial desta grande 
cidade projetada enquanto potência econômica, onde os "maiores" e "melhores" se encontram, se concentram nesta cidade "do trabalho, da ciência, da cultura e da tecnologia". Essa é a cidade de São Paulo que costumamos apresentar, mas todos nós que moramos e/ou trabalhamos nesta cidade temos de forma muito clara que São Paulo também é a cidade da saturação, da pobreza, do feio, do retrógrado, da autosegregação, qualificações não tão nobres, mas que fazem parte deste grande universo que é a cidade de São Paulo.

Embora a grande metrópole paulistana seja simplesmente encantadora, não é nesta grande obra urbanística que vamos nos concentrar para explicar a produção espacial, mas é numa cidade da região metropolitana de São Paulo que vamos nos aproximar o quanto pudermos para estudar a sua produção espacial.

É na cidade de Cotia, um município bem próximo da cidade de São Paulo, que vamos nos concentrar. É certo que ao estudarmos Cotia (ou mais precisamente uma região de Cotia, a Granja Viana), vamos "olhar" também a cidade metropolitana paulistana, já que é esta que tem fundamental influência sobre aquela na sua produção espacial.

Esta relação entre a cidade de São Paulo e a produção espacial de Cotia, tentamos explicar por dois fatores, que embora abordados aqui de forma individualizada, são integrados. Os dois aspectos são criados pelo mercado e constituem um fato bastante interessante para na região. Afinal

As necessidades da sociedade estão relacionadas com a capacidade de produção da sociedade, pois a relação que se estabelece entre o homem e o meio é mediada pelo processo de trabalho, através do qual a sociedade produz o espaço no momento em que produz sua própria existência. (CARLOS, 2003:31)

É notório, a sociedade contemporânea sente necessidade das coisas mais adversas, as necessidades são confundidas com o desejo, se encerra na condição do consumo, as pessoas necessitam consumir desde uma massagem (cobrada e paga), até um espaço demarcado e reconhecido como seu. O espaço reflete justamente isso...o consumo. 
Bem, por hora vamos desconsiderar o marketing e vamos a alguns dados ainda a respeito da cidade de São Paulo. Pode ser que, a princípio, não faça muito sentido a proposta ser analisar a Granja Viana e ficarmos discutindo sobre a metrópole paulistana. O fato é que com a expansão urbana acelerada da cidade de São Paulo houve aumento da poluição ambiental em vários níveis: temos a poluição do ar, das águas (inclusive das áreas de mananciais), do solo, visual, auditiva, enfim, existe uma poluição de toda ordem no grande centro.

Paulatinamente, desde a década de 1940, determinadas parcelas da população paulistana, começou a procurar novas opções de espaços, de início de lazer para passar finais de semanas e férias, mas com o "acirramento" da poluição e da violência urbana (os fatos realmente existem, mas o acirramento entre aspas deve-se ao fato de que a mídia e os empreendedores imobiliários promoveram um "sensacionalismo" em torno da questão, ampliando a problemática) o único caminho que foi apontado como possível (tanto na mídia como no marketing imobiliário foi o "abandono" da cidade outro espaço "mais tranqüilo").

Assim essa parcela da população é levada a procurar lugares que pudessem oferecer uma "qualidade de vida" que eles sentiam como perdida e, deste modo, as opções ficaram por conta dos espaços periféricos a esta mega cidade. Cotia, é um bom exemplo para isso.

A cidade de Cotia gozava de um certo "prestígio" pelo fato de que o município fazia parte do chamado Cinturão Verde da cidade de São Paulo. Foi incorporado ao marketing de venda de espaços da região da Granja Viana a proximidade às áreas verdes. Nas propagandas que vendiam espaços na região anunciavam-se grandes lotes que eram valorizados pela presença de Mata Atlântica remanescente ou pelos trabalhos paisagísticos, veja bem, mesmo tão distante da Reserva Florestal do Morro Grande. 


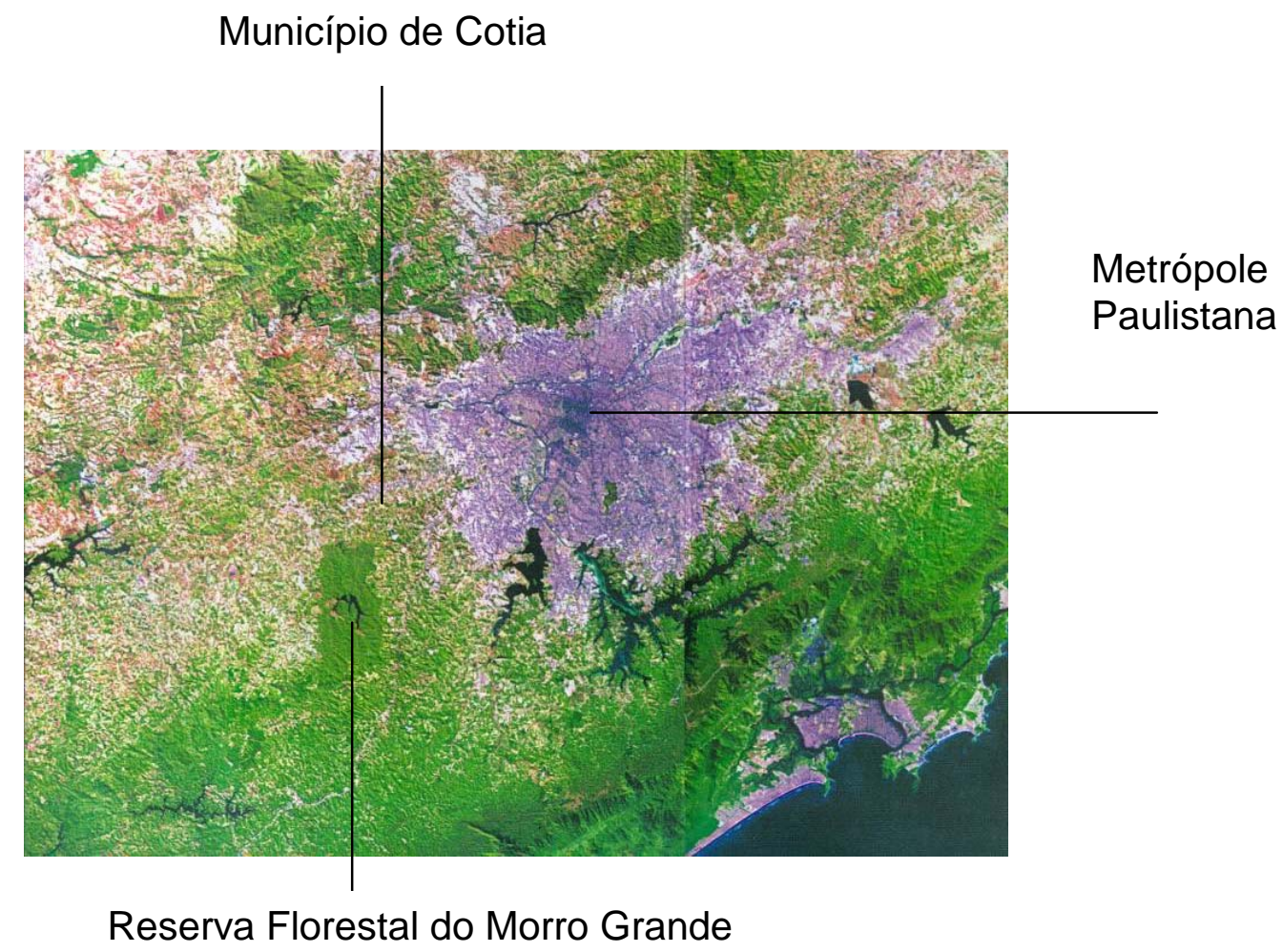

Fonte: Fotografia de Satélite Landsat fornecida pela Reserva da Biosfera do Cinturão Verde da Cidade de São Paulo - Instituto Florestal de São Paulo/2004.

Bem, não podemos ignorar o fato de que "... a ordenação das "zonas" e das "áreas" urbanas se reduz a uma justaposição de espaços, funções, de elementos práticos. Setores e funções estão estreitamente subordinados aos centros de decisão..."(LEFEBVRE, 2001:77). É importante realçar esse aspecto porque como já dissemos, Cotia, ou mais precisamente, a região da Granja Viana tem como centro de influência a cidade metropolitana de São Paulo. Ainda que formalmente o centro administrativo da região granjeira esteja em Cotia, como para regulamentação de logradouro, impostos, pedidos de água, luz ou telefone fixo e coisas afins, é na metrópole de São Paulo que os moradores granjeiros mantêm seu trabalho, suas relações sociais e seu lazer, bem como é de São Paulo que partem as estratégias de vendas e marketing das áreas, assim como é nela que se encontram os possíveis compradores desses espaços . 
Vamos tentar discutir melhor essa questão, a utilização do discurso ambiental para legitimar a busca por lugares que possam oferecer "melhor qualidade de vida" e a incorporação de algumas características no valor dos imóveis.

Cotidianamente ouvimos dizer que a região granjeira aparece como a solução para uma classe social alto padrão social que procura no ideal ecológico a qualidade de vida perdida na cidade, incluído aqui a questão também da segurança, ou seja, o retorno a uma natureza elementar ${ }^{4}$, mas com todo conforto que o meio de vida urbano pode oferecer.

A respeito dos problemas da vida urbana, tendemos a considerar, ao menos como discurso ideológico que

...na fase crítica, a natureza aparece no primeiro plano dos problemas. Associadas e concorrentes, a industrialização e a urbanização devastam a natureza. A água, a terra, o ar, a luz, os "elementos" estão ameaçados de destruição... (LEFEBVRE, 2002:36).

Embora os meios de produção estejam alcançando um nível tecnológico cada vez maior, há um verdadeiro entrave para o sistema produtivo posto pela dificuldade em superar o possível esgotamento dos recursos naturais ${ }^{5}$. A mídia vem difundindo desde 1960 a criação de um ambiente hostil para a humanidade com a paulatina "supressão" da natureza, mas junto a este alardeamento o estímulo ao consumo quase que "compulsivo" da sociedade é garantido pela mesma mídia de massa, e é justamente a homogeneização dos modelos produtivos e padrões de consumo que, de acordo com LEFF (2001:84),

...levou a desestabilizar os equilíbrios ecológicos, a desarraigar os sistemas culturais e a dissipar os sentidos da vida humana. A busca de status, de lucro, de prestígio, de poder, substitui os valores tradicionais: o sentido de enraizamento, equilíbrio, pertença, coesão social, cooperação, convivência e solidariedade.

Ou ainda mais do que a substituição de valores, a denúncia de que

\footnotetext{
${ }^{4}$ Há uma passagem literária bem interessante de LEFEBVRE (2002:35) a este respeito, onde coloca que “...a Cidade aparece como segunda natureza, pedra e metal, erigida sobre a natureza inicial e fundamental, a dos elementos, a terra e o ar, a água e o fogo. Essa segunda naturalidade adquire seu paradigma, seu sistema de oposições pertinentes: o brilhante e o sombrio, a água e a pedra, a árvore e o metal, o monstruoso e o paradisíaco, o rugoso e o polido, o selvagem e o artificial..."
} 
... entramos en un mundo en el que el capital no se limita a apropiarse de la naturaleza...Se trata más bien de un mundo en el que el capital rehace a la naturaleza y a sus productos biológica y físicamente (y política e ideológicamente) a su propia imagen e semejanza... (O'CONNOR, 2002:33)

O discurso ecológico que tenta ser homogeneizador reforça a idéia de que a mesma natureza que serviu ao homem enquanto meio e matéria-prima, poderia colocar em xeque a própria existência humana, por meio dos "riscos ambientais", o que realmente não podemos negligenciar.

A aceitação de um discurso que enfatiza a questão dos riscos ambientais tão presentes nas grandes cidades (mas não necessariamente de um questionamento quanto à questão do consumo) levou parcela da sociedade a buscar uma vida alternativa e desta forma um mercado "ambiental" foi criado. Temos desejos tornados necessidades, que vão desde uma alimentação mais equilibrada e orgânica até a procura por qualidade de vida em espaços fechados, representados pelos condomínios e bolsões residenciais em lugares como a Granja Viana.

O discurso ecológico tem como suporte a ciência e, como promotora e divulgadora dos fatos, a mídia. Por meio tanto da ciência como da mídia há uma incorporação do risco ambiental na construção das representações sociais que se dá na aceitação de uma força natural que resultará inicialmente numa coação social, num processo exposto por DURKHEIM (1978:148) da seguinte forma:

...Assim, para fazer com que 0 indivíduo se submeta voluntariamente a ela, não é necessário a recorrer a nenhum artifício, basta fazer com que ele tome consciência do seu estado de dependência e de inferioridade naturais, quer por uma representação sensível e simbólica, através da religião, quer por sua noção adequada e definida, através da ciência...

Desta forma, a chamada crise ecológica vai assumindo uma importância cada vez maior na sociedade global contemporânea, propiciando a venda de espaços "naturais". Tornou-se comum a preocupação generalizada da sociedade local com o

\footnotetext{
${ }^{5}$ Não iremos aqui entrar na discussão que o termo "recursos naturais" vem promovendo no meio acadêmico.

${ }^{6}$ Tradução livre da autora: “...entramos em um mundo em que o capital não se limita a apropriar-se da natureza. Trata-se bem mais de um mundo em que o capital refaz a natureza e a seus produtos biológicos e fisicamente (e política e ideologicamente) a sua própria imagem e semelhança..."
} 
meio/ambiente, afinal todos os holocaustos da atualidade são resumidos ao distanciamento do homem daquela natureza perdida. O discurso ecológico acabou servindo para encobrir as problemáticas sociais. Este discurso foi incorporado principalmente no meio urbanizado, talvez porque

A natureza (...), não é algo natural, mas fruto do longo processo de superação de um espaço primitivo e selvagem, onde não havia lugar para qualquer produção excedente, pelo espaço de uma outra sociedade, onde as relações de poder estabelecidas entre os homens exigirão a produção de um número cada vez maior de "artifícios". E quanto maior a produção destes "artifícios", mais evidente a natureza se torna! (CARVALHO, 1999:30)

$\mathrm{O}$ "surgimento" de uma idéia que cria a necessidade em resgatar uma "qualidade de vida" potencializando a necessidade da aproximação do homem a natureza como única possibilidade de conseguir o restabelecimento do equilíbrio há muito perdido, ignorando, portanto o fato de que a realidade concreta das grandes cidades é resultado de uma forma de estabelecimento das relações sociais.

Na cidade passou-se a incorporar como única possibilidade de relações à função econômica, furtando-se a perspectiva dada pelo vivido. Assim sendo, percebe-se que pouco se divulgam as mobilizações da sociedade citadina no sentido de resgatar o vivido na cidade, a ocupação pela população de suas praças, parques e áreas de lazer públicas. A estratégia elaborada para a reprodução do capital nega a cidade, daí a fuga, para os que podem e querem, desse espaço nas suas mais diversas formas.

A saída encontrada por parcelas da sociedade é a auto-segregação e a fragmentação ainda maior do espaço acentuando as diferenças sociais e a hierarquização da sociedade, do espaço, das relações. O medo e a insegurança, também gerados pelo próprio processo de reprodução capitalista, promovem o acirramento destes mesmos medos e inseguranças, a omissão do encontro e da possibilidade do confronto enquanto a cotidianidade e a capacidade de "transgredir" o dia-a-dia ficam, tendencialmente, anulados.

Aqui destacamos que ao mesmo tempo em que essa parcela da sociedade nega a cidade existente, ela passa a promover uma contínua busca por um espaço novo, um 
lugar que oferecesse o desejável conforto, um bem-estar ${ }^{7}$ atrelado à aproximação do homem ao "verde", condição aqui considerada como fruto das representações sociais ao assumir o "discurso ideológico-ecológico" como condição necessária para garantir uma vida mais saudável.

E é exatamente neste ponto que vamos abordar a "raridade espacial" criada da esfera global por meio da disseminação do "discurso ambiental", e constituída na esfera local por meio da super valorização de espaços que condizem com a aceitação do discurso generalizado.

Se por um lado a constituição, em determinados locais das cidades metropolitanas, de centralidades marcadas pela existência de prédios inteligentes, infraestrutura e todo aparato moderno e avançado de telecomunicação e tecnologia urbana pode dar o status de raridade espacial a determinadas localidades, o contrário também é verdade, ou seja, a incorporação do discurso ambiental pelo mercado imobiliário fez com que algumas localidades fossem elevadas ao status de raridade justamente por não ter as mesmas qualidades dessa forma de "raridade urbana", mas possuírem, não "mato" mas, Matas, no caso paulista, a Mata Atlântica .

Podemos explicar essa tendência segundo um esclarecimento de SANTANA (2001:179) ao dizer que

...A natureza se torna raridade, em especial, na paisagem urbana e industrial, isto é, a "natureza pura" se torna raridade na vida na cidade. Aqueles bens ganham valor de troca em função de sua raridade. Este movimento histórico implica na entrada destes bens no circuito econômico enquanto novas mercadorias dadas a uma necessidade histórica.

Tomando um discurso que enfatiza a cidade de São Paulo como espaço cuja paisagem urbana e industrial é desprovida da "natureza pura" ou ainda da "primeira natureza", percebemos que a medida em que a sociedade assume como verdade a "deterioração" da vida na cidade paulistana temos como um dos efeitos a saída,

\footnotetext{
${ }^{7}$ Entendemos a idéia de "bem-estar" como algo que representa um determinado conforto que é subjetivo e submetido a ideologia também.

${ }^{8}$ Devemos atentar para o fato de que embora esses espaços oferecidos pelo mercado imobiliário que "privilegia" o verde apela para uma paisagem natural e proponha uma vida com uma "qualidade de vida" atrelada ao "espírito ecológico", na prática a infra-estrutura, a tecnologia e a comunicação tornam-se
} 
também por esse motivo, de uma parte da população de alto poder aquisitivo da cidade de São Paulo para outras cidades/áreas da sua Região Metropolitana, capazes de oferecer essa aproximação a "natureza" e/ou locais na cidade que ainda possuem áreas cada vez mais raras ${ }^{9}$.

Na Região Metropolitana de São Paulo verificamos a configuração de um "Cinturão Verde" e de acordo com SANTANA (2001:180) "... as "novas raridades" servem de estratégia para a reprodução do capital por adquirirem valor de troca e, por conseguinte, transformarem-se em mercadorias...". Assim, em diversas áreas de cidades do entorno da cidade paulistana há a apropriação (via propriedade privada) da sua "primeira" natureza remanescente e, por meio do marketing imobiliário, atraem compradores destes espaços.

É exatamente neste aspecto, o da "raridade da natureza", que o mercado imobiliário de lugares como na Granja Viana consegue por meio de seus condomínios e bolsões residenciais, conforme croqui a seguir, despertar o "desejo" de consumo de um espaço que conseguiu juntar a oferta da natureza, junto com segurança, conforto, beleza e requinte.

imprescindíveis enquanto conforto no dia-a-dia dos proprietários destes espaços e na agregação de valor do próprio imóvel.

${ }^{9}$ É o caso da Cantareira por exemplo, uma área que fica ao norte da capital paulistana e que é protegida por lei por tratar-se do cumprimento da legislação que garante a proteção aos mananciais, constituindo indiretamente um espaço de raridade na grande metrópole. 


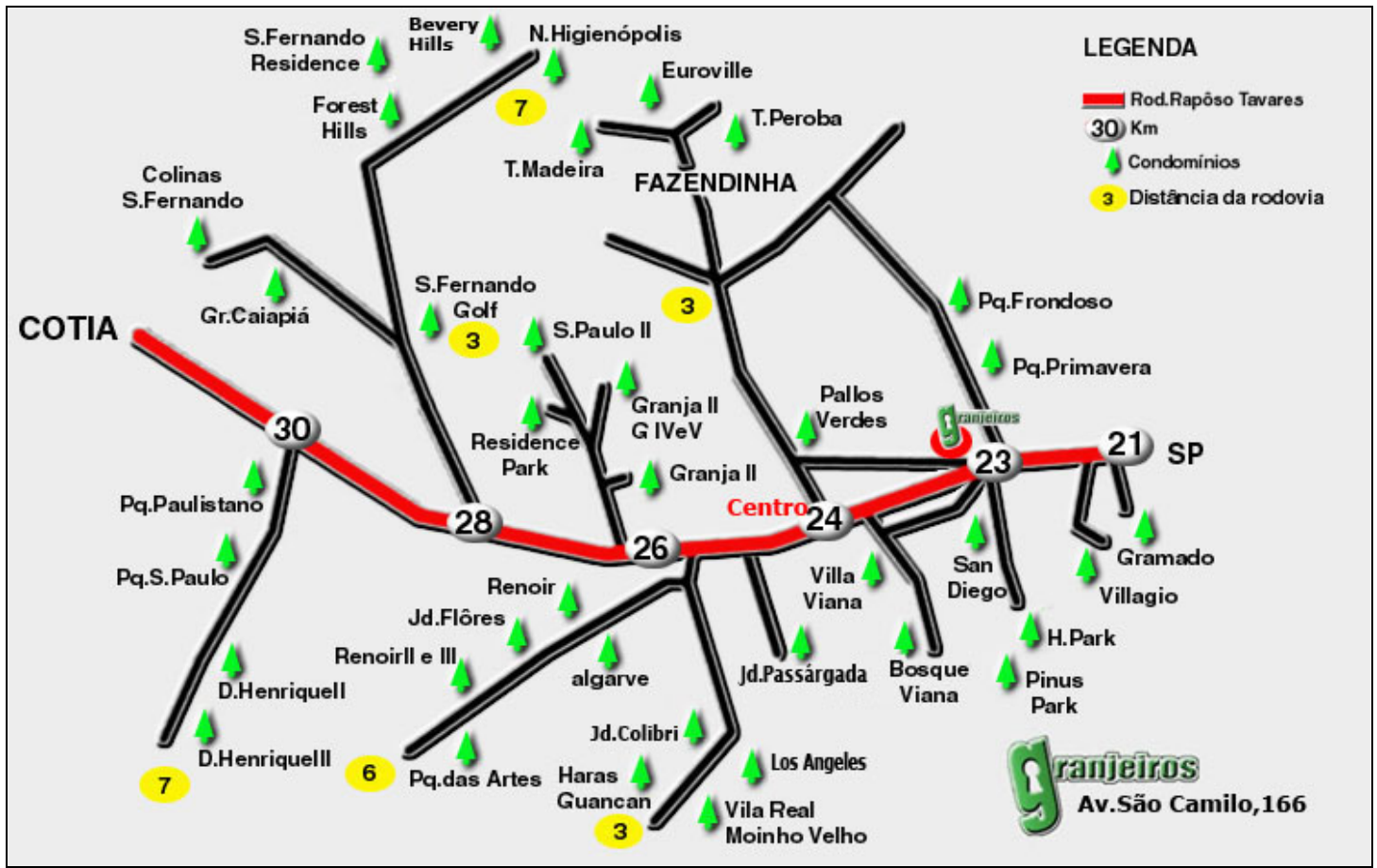

Fonte: www.granjeiros.com.br (junho/2006).

Trata-se, como nos diz CARLOS ( 2001) do consumo do espaço.

A especulação imobiliária conseguiu agregar ao valor da propriedade uma ideologia que enfatiza uma certa "qualidade de vida", por meio de um discurso globalizado. Assim, temos uma relação direta das esferas global e local quanto ao poder do capital no espaço, com o fortalecimento de discursos que mesmo originandose em outras escalas (no caso global) podem valorizar determinadas localidades.

A veiculação pela mídia de todos os condicionantes que geram a ameaça à segurança da sociedade (sem necessariamente explicar que processos conduzem a isso), e, por sua vez, a aceitação dos riscos que dão horizontes ao medo permanente, impulsiona o mercado que passa a fazer uso desse discurso (uma associação de idéias ligadas à violência e ao discurso ambiental), incorporando estrategicamente essa aceitação como constituição de novas necessidades de consumo, ou seja, no momento em que a sociedade assumiu a "crise ecológica". O mercado passou a gerar novas necessidades - consumir produtos ecologicamente corretos, aproximar-se da natureza por meio do turismo ecológico, procurar uma vida mais harmônica e equilibrada por meio de novos projetos imobiliários que prometem uma vida qualitativa em meio ao 
"verde" - que passaram a ser objetos de desejo, da sociedade consumista, como qualquer outro produto. Desta forma

Fazendo apelos à ecologia, saúde, ordem, lazer e, é claro, segurança, os anúncios apresentam os condomínios fechados como o oposto do caos, poluição e perigos da cidade. Essas imagens são compartilhadas por aqueles que decidem deixar 0 centro para habitar os novos conjuntos... (CALDEIRA, 2000: 266)

No entanto, há um outro elemento que nos faz refletir sobre a constituição dos bolsões residenciais e condomínios em cidades periféricas da metrópole paulistana, como é o caso de Cotia: trata-se do valor do preço do solo. Existem muitos lugares cujos muros cercam verdadeiros oásis no coração da grande metrópole, são condomínios de alto padrão que atendem as exigências de determinadas camadas da sociedade, ainda que muitos enfatizem o ser "amante da natureza". Ainda que não passe de um discurso, novos espaços estão sendo criados e incorporam esses aspectos vinculados a "natureza", sendo a eles conferidos valores e privilégios que poucos podem pagar. Aos que pagam por esse tipo de patrimônio cabe por ele zelar.

Mesmo considerando todos os argumentos ecológicos e ambientais para justificar o aparecimento de bolsões ou condomínios residenciais, isto não é o suficiente para explicar a (re) produção espacial da Granja Viana, já que todos os aspectos aqui já levantados explanados, podem ser no máximo "considerações" que os moradores granjeiros fazem ao optar decididamente em vir morar na região, mas o aspecto preponderante é aquele que diz respeito ao capital.

Embora a região seja um expoente da cidade de Cotia em relação a "requinte e bom gosto" (de uma camada populacional), melhor dizendo, que ostente uma evidente riqueza nas moradias, carros, vestuários, colégios, lazer (autódromo, jóquei, quadras de tênis, campos de golfe entre outros), tendemos a compreender que a Granja Viana se porta como o reduto de uma classe social "não tão abastada assim", já que a população granjeira é constituída por duas características de ordem financeira, ela é fruto de uma "classe social em ascensão" ou, ao mesmo tempo, carrega em si uma fração considerada de pessoas que estejam em plena "decadência financeira", essa última característica é algo muito próximo da realidade de uma boa parte dos moradores da 
região, que invariavelmente ostentam algo que não possuem, como mostraremos adiante.

De acordo com LEFEBVRE (2001:63)

A fetichização da relação formal "significante-significado" comporta inconvenientes mais graves. Ela aceita passivamente a ideologia do consumo dirigido...É assim que a publicidade para os bens de consumo se torna no principal bem de consumo...Consome-se tantos signos quantos objetos: signos da felicidade, da satisfação, do poder, da riqueza, da ciência, da técnica, etc...O signo é comprado e vendido.

Faz-se necessário notar aqui duas condições relevantes quanto a região granjeira, enquanto produção espacial voltada para o mercado imobiliário de alto padrão: o primeiro diz respeito a região dentro de uma cidade da região metropolitana, a segunda é a posição da mesma região enquanto periferia da cidade paulistana.

Essa distinção traz como diferença relevante o seguinte fato, a Granja Viana como região da cidade de Cotia, melhor dizendo, para os cotianos (moradores de Cotia) a Granja Viana é uma região nobre e somente as pessoas de classe social alta é quem podem usufruir de fato de tudo o que a região tem a oferecer.

Há pouco tempo, numa escola pública de um bairro periférico de Cotia, o Jd. Araruama foi presenciada a conversa entre uma secretária e uma professora que estavam lendo uma revista local (da Granja Viana), e vendo a propaganda de uma escola (de fachada muito bonita, totalmente arborizada e com muito espaço). As duas interlocutoras começaram a comentar como era linda aquela escola, quando a secretária sentiu a curiosidade de saber qual era o local e fez a pergunta à professora que respondeu "Fica na Granja...", a secretária respondeu como se tratasse de algo muito óbvio: "Ah, então está explicado!".

Toda a população de Cotia tem a Granja Viana como um lugar totalmente inacessível, como se tudo que estivesse contido naquele espaço fosse de uso apenas dos granjeiros, mesmo os espaços tidos como públicos, como é o caso da "Capela de Santo Antônio", a Biblioteca Cecília Meirelles ou o ASSA (Associação Santo Antonio - é um espaço filantrópico da capela, onde a prefeitura e Organizações Não- 
Governamentais oferecem cursos, oficinas ou entretenimento como musicais, corais e peças teatrais, o valor de entrada é geralmente um quilo de alimento não perecível).

As pessoas que passam de ônibus pela região (cortada pela rodovia Raposo Tavares), principalmente nos horários de pico (às 6:00 ou às 19:00), tem por algo muito comum ouvir alguém (geralmente mulheres) dizer com "muito orgulho" de um parente próximo (ou amigo) que trabalha para algum granjeiro e é um deleite para todos ouvir falar da casa, dos costumes dos patrões, dos bens ou peculiaridades do dia-a-dia daquela região. Somente no final da conversa é que alguém lembra o quanto é bom ser pobre porque a gente não precisa ficar preocupado com "frescuras", e há uma certa necessidade de reforçar que somos mais "felizes" do que os ricos que tem que andar em carros blindados e ter altos muros em suas casas para se protegerem.

A Granja Viana porta-se realmente como uma região auto suficiente, ou seja, os moradores deste lugar, salvo por motivos muito específicos, não precisam sob qualquer pretexto se deslocar para a região do centro de Cotia ou ainda para Caucaia do Alto (exceto para a prática de esportes de aventura, mas isso ainda é muito esporádico). A Granja é como se fosse um território de exclusividade, porta-se como se

Esses territórios do urbano são inscrições espaciais com limites absolutos, visíveis no conjunto da área edificada. Seus limites formam aquilo que se pode identificar como uma "linha dura", que são as 'zonas' de contato, marcadas por singulares experiências de viver o processo urbano. (SEABRA, 2004: 184)

Embora a Granja Viana seja apenas uma dentre as três regiões de Cotia, é fato que os moradores não costumam se identificar como moradores do município ou ainda do seu bairro, como acontece nas áreas periféricas da cidade. Quando conversamos com alguém de Caucaia do Alto e perguntamos de onde ele é a resposta pode vir de duas formas: "Sou de Cotia." ou "Sou dos Pereiras.", "Sou da Capelinha.", "Sou dos Mendes." O mesmo acontece quando conversamos com alguém que more na região central de Cotia, ele poderá responder também de duas formas: "Sou do Centro de Cotia.", ou "Sou do Jd. Panorama.", "Sou do Atalaia.", "Sou do São Joaquim.", somente na Granja Viana percebemos uma tendência das pessoas se identificarem independentemente do bairro onde more como aquele que mora na "Granja Viana". 
Dá status quando alguém diz que é morador da Granja Viana, embora as roupas e o carro (sua ausência ou o tipo de carro que está dirigindo ou entrando) sejam indicativos para sabermos se trata de um granjeiro rico ou pobre, o respeito e uma atenção especial é dado como algo inevitável à alguém que é morador daquele lugar.

A idéia de que a região é constituída por jornalistas, artistas, intelectuais, empresários, enfim uma elite de primeira grandeza, é mais reforçada enquanto poder econômico e político, à medida que a população vê a construção de verdadeiras reproduções paulistanas de comércio e prestadores de serviço bem no caminho de passagem do seu dia-a dia (estamos nos referindo a rodovia Raposo Tavares), ou constata os muros cada vez maiores e com cercas elétricas, a quantidade de seguranças ou policiamento que ronda aquela região por uma questão de segurança.

A região granjeira aparentemente consegue manter sua "vida" independentemente do município: é como se a região estivesse desvinculada, fosse autônoma, ou ainda, emancipada da região, para a maior parte das pessoas moradoras dessa região. Quando interrogadas sobre o lugar onde moram, geralmente respondem "na Granja Viana", como se Cotia fosse uma "cidade vizinha". No entanto, o mesmo não acontece com relação à cidade metropolitana, sendo que a maioria dos moradores da Granja não conseguem desvincular sua "vida" da cidade de São Paulo.

Percebemos que um novo espaço foi criado para atender às necessidades dos granjeiros (todos os moradores do município são cotianos, somente os moradores da Granja Viana intitulam-se granjeiros, denotando a identidade forte daquela população elitista com a região). A região granjeira permite encontrarmos lojas e serviços que o centro tradicional não tem, e cuja estrutura (e preços praticados nos estabelecimentos) não permite o acesso dos demais cotianos ao centro granjeiro. Assim

A reprodução tem o sentido da constante reprodução das relações sociais estabelecidas a partir de práticas espaciais como a acumulação, preservação, renovação. A reprodução do espaço urbano é um fenômeno contínuo, em movimento, o que significa que a cidade vai-se transformando à medida que a sociedade se metamorfoseia. (CARLOS, 2001: 20).

Os espaços urbanos que constituem a cidade são produzidos de forma a reproduzirem a divisão, a hierarquização e as contradições sociais. $\mathrm{Na}$ atual fase da 
história econômica do município vemos um estímulo público ao mercado imobiliário granjeiro, e daí há a permissão da formação de um aparato mercadológico que utiliza em suas estratégias um discurso vinculado à "qualidade de vida" num ambiente "idílico e paradisíaco" para um público bem definido, da classe média alta paulistana.

É interessante perceber como as estruturas, as formas e as posturas definem um determinado tipo de comportamento e nos parece muito coerente o fato de que, de acordo com SEABRA (2004:183), “... à medida que a condição de pobre, como pobre urbano se definia, entre os mais ricos criou-se a necessidade de administrar a separação, aqui identificada como auto segregação...".

No entanto, essa condição muda um pouco de foco quando pensamos nos valores que o espaço destinado às residências tem na Granja Viana e respectivamente em São Paulo. Dessa forma quando olhamos a Granja Viana como uma região próxima da cidade de São Paulo que pode oferecer bons terrenos ou boas casas em bolsões ou condomínios residenciais por um valor de troca que, embora altos para a maioria dos moradores da cidade cotiana são bem acessíveis para pessoas que estão em início de ascensão social, ou bem ao contrário, para aquelas que estão em decadência social na cidade de São Paulo.

Os preços para a compra de uma boa casa na Granja Viana, num residencial muito bem estruturado, são inferiores aos valores de imóveis similares em bairros de classe média alta da cidade de São Paulo. Na cidade de São Paulo, o valor agregado ao imóvel de São Paulo está ligado a própria localização, Os imóveis de alto padrão estão encravados no coração da metrópole paulistana (ou seja na cidade de São Paulo): esse é o discurso empregado no marketing para as vendas dos empreendimentos mais luxuosos de São Paulo, como é o caso da venda de um novo conjunto residencial nos Jardins $^{10}$ ou ainda em novas áreas como ao lado da Marginal Pinheiros como o empreendimento Panamby.

Morar nos Jardins é ter todos os privilégios de uma região nobre, que se valorizou ainda mais, em virtude de um moderno e

10 Uma das áreas residenciais mais luxuosas na cidade de São Paulo, os Jardins, referem-se basicamente aos bairros Jardim América, Jardim Paulistano, Jardim Europa e Cerqueira César, que são margeados pelas avenidas Rebouças, Paulista, Nove de Julho e Brigadeiro Faria Lima. 
sofisticado projeto de urbanização, paisagismo e despoluição visual.

Aqui você está cercado pelo melhor roteiro gastronômico da cidade, com excelentes restaurantes, bares e bistrôs, além de excelentes opções de compras, nas diversas lojas de grife, numa verdadeira passarela da moda. Ao sair para se divertir, você se depara com as melhores galerias, cinemas, museus e parques, respirando arte e bom gosto.

Você conta ainda, com a Nova 9 de Julho, que se tornou o novo Boulevard de São Paulo, com seu maravilhoso paisagismo ao redor do atual anel viário, que recebeu recuperação asfáltica, fiação subterrânea, nova iluminação, enfim, uma total transformação urbanística... (www.imovelweb.com.br 16/06/2006)

Embora tenhamos um grande discurso ecológico que busca valorizar determinadas áreas, como a que já discutimos neste capítulo, devemos aqui reconsiderar a saída de algumas pessoas de São Paulo que buscam "equilíbrio ambiental" em lugares como Cotia, por meio da Granja Viana, até porque os condomínios da cidade paulistana, ou até mesmo os bairros mais elegantes como Alto de Pinheiros ou Morumbi, tem na medida certa a arborização e o paisagismo procurados na Granja Viana.

O acesso financeiro a estes espaços é que nos parece ser o pano de fundo desta questão, ou seja, a maioria das pessoas que com que conversamos (além das reportagens que lemos entrevistas na mídia impressa e ou televisiva) apontam como principal responsável da sua vinda de São Paulo para a região granjeira, justamente a possibilidade de uma aproximação maior com o verde, um ambiente mais calmo, mais tranqüilo, mais clean. O curioso é que podemos encontrar lugares que possam oferecer isso e muito mais (já que o morador não vai precisar perder tempo em congestionamento da rodovia Raposo Tavares para ir da sua casa para o trabalho ou o teatro e cinema e vice-versa, se ele já está muito próximo destes). De acordo com CARLOS (2003:55)

Um tipo de moradia é aquele destinado às classes de renda média e alta que fogem da metrópole em busca da natureza e do ar puro, longe dos inconvenientes que o "progresso" trouxe. É o caso da Granja Viana (a oeste)... 
Entendemos, como CARLOS, que o espaço granjeiro (parte dele) é realmente destinado às classes de renda média e alta, mas não é somente o "reencontro" com a natureza que levam essas pessoas à "fugirem" da metrópole paulistana; deve-se também levar em consideração o fator econômico, determinante para "aceitar" a opção granjeira.

Se observarmos a propaganda dos imóveis abaixo entenderemos um pouco melhor o motivo que faz algumas pessoas optarem por morar na Granja Viana e não num respeitável condomínio de São Paulo. A pesquisa a seguir foi feita por meio de site e as determinantes de busca eram: Casa (excluímos os apartamentos porque esses poderiam ser considerados populares, bem como não possibilitaria a comparação com a Granja, já que nela são proibidas construções de prédios) e Condomínio (a opção por condomínio foi por levar como relevante a busca por lugares que possam oferecer "segurança").

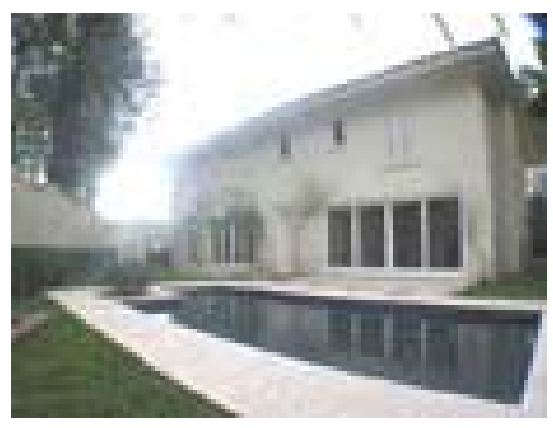

MORUMBI - SÃO PAULO - SP

Residência luxuosa, 5 suites com closet, salas de estar, jantar e almoço, escritório, home theater, acabamento em mármore importado, $700 \mathrm{~m}^{2}$.

$\mathrm{R} \$ 2.800 .000,00$

www.portaldoimovelsp.com.br 16/06/06

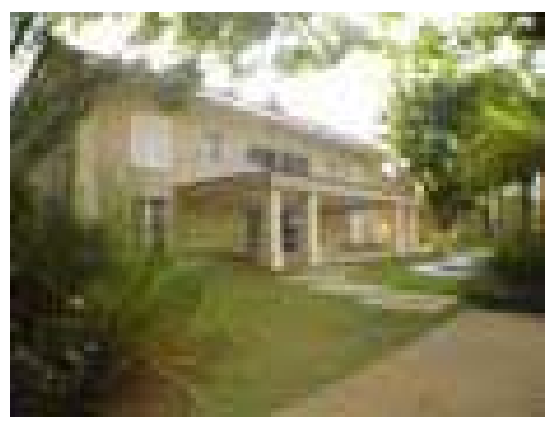

MORUMBI - SÃO PAULO - SP

Residência luxuosa, $1.100 \mathrm{~m}^{2}$ de terreno, 4 suítes com closet, suíte máster com dois banheiros, sala intima, home theater, living voltado para jardim, sala de ginástica, churrasqueira. $\mathrm{R} \$ 4.300 .000,00$ www.portaldoimovelsp.com.br 16/06/06 

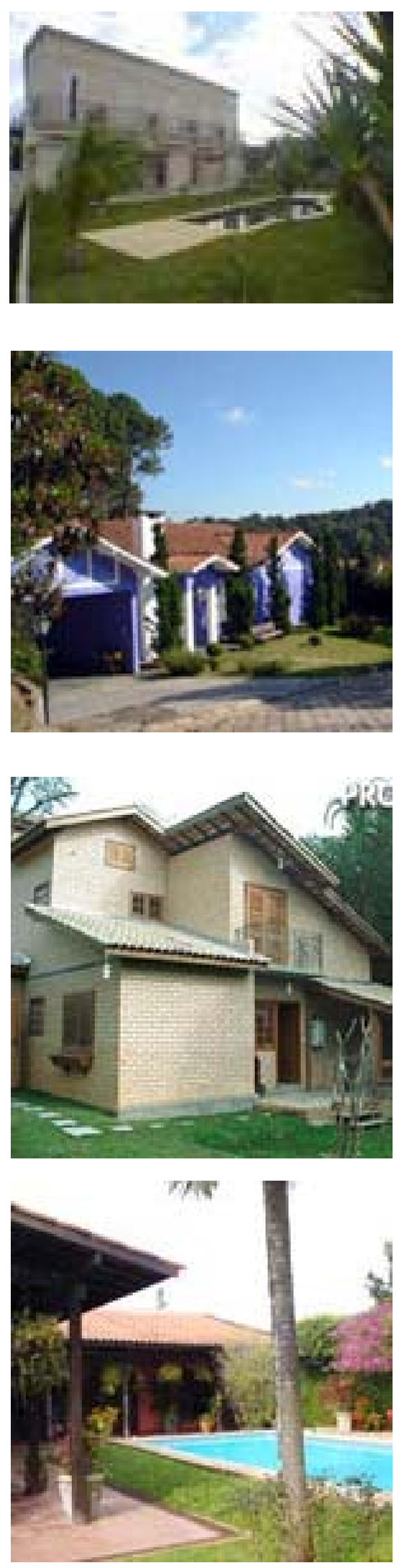

MORUMBI - SÃO PAULO - SP

4 amplas suites c/closet, living $p / 4$ ambientes voltado p/lindo jardim e piscina c/vista panoramica,home theater, elevador, sala jantar, s. almoço, copa, coz. planejada, salão de festas, subsolo de garagem para 10 carros, finíssimo acabamento, $1.000 \mathrm{~m}^{2}$ de terreno. $\mathrm{R} \$ 4.900 .000,00$

www.portaldoimovelsp.com.br 16/06/06

CIDADE JARDIM - São Paulo - SP

Casa em condomínio fechado, com apenas 5 casas. Impecável e de muito bom gosto. Pronta para morar.

Preço: $\mathrm{R} \$ 1.500 .000,00$

Área útil: $546 \mathrm{~m}^{2}$

Condomínio: $\mathrm{R} \$ 1.560,00$

IPTU: 10 X R \$ 500,00

www.wertheimimoveis.com.br 16/06/06

CIDADE JARDIM - São Paulo - SP

Casa em condomínio na Cidade Jardim. Bom gosto e aconchego.

Preço: R\$1.500.000,00

Área útil: $450 \mathrm{~m}^{2}$

Condomínio: $\mathrm{R} \$ 2.000,00$

www.wertheimimoveis.com.br 16/06/06

JARDIM PAULISTANO - São Paulo - SP

Casa em condomínio fechado muito procurado.

Vizinho ao Shopping Iguatemi.

Preço: $\mathrm{R} \$ 3.200 .000,00$

Área útil: $689 \mathrm{~m}^{2}$

Condomínio: $\mathrm{R} \$ 1.350,00$

IPTU: 10 X R \$ 500,00

www.wertheimimoveis.com.br 16/06/06 

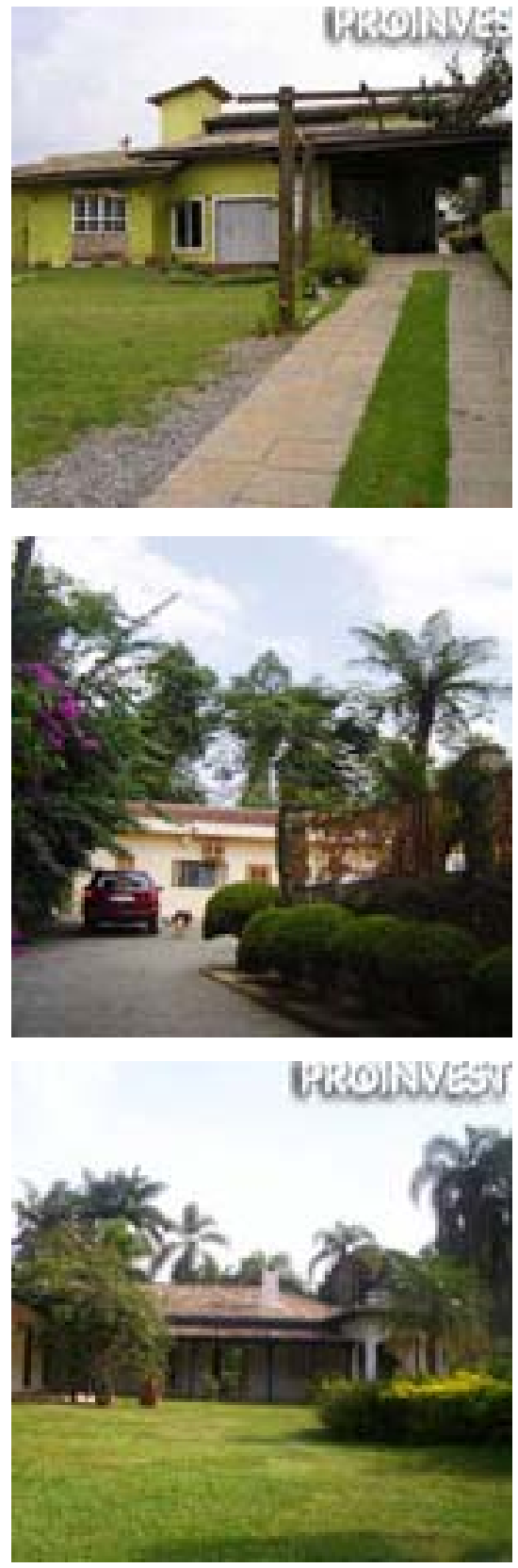

GRANJA VIANA - Cotia - SP

OPORTUNIDADE!! $1200 \mathrm{~m}^{2}$ ter, $350 \mathrm{~m}^{2}$

ac, 3 dorms (1 suíte), salas de estar, jantar e living, lareira, churrasqueira, sl. Festas, fogão caipira e forno de pizza. Área do terreno: $1200 \mathrm{~m}^{2}$

Área construída: $350 \mathrm{~m}^{2}$

Valor: $280.000,00$

(11) 4612-2599

www.granjaviana.com.br 16/06/06

GRANJA VIANA - Cotia - SP

Casa térrea com espaço muito grande para construção de piscina e área de lazer.

Árvores frutíferas: Jardim amplo.

Área do terreno: $1960 \mathrm{~m}^{2}$

Área construída: $461 \mathrm{~m}^{2}$

Valor: $400.000,00$

(11) 8599-9940/ 4612-9928/ 5512-1385

Via dos Lótus, 162 - Jardim Colibri

www.granjaviana.com.br 16/06/06

GRANJA VIANA - Cotia - SP

Imperdível!!! 5655m² ter, $700 \mathrm{~m}^{2}$ ac, 4 dorms (2 suítes), 1 closets e 1 hidro, várias salas, lareira, escritório, piscina, churrasqueira, cs.caseiro!!!

Área do terreno: $5655 \mathrm{~m}^{2}$

Área do construída: $700 \mathrm{~m}^{2}$

Valor: $1.200 .000,00$

(11) $4612-2599$

www.araniaviana.com.br 16/06/06

Observando os anúncios, podemos apontar alguns elementos relevantes, o primeiro é o alto valor dos imóveis localizados em São Paulo, pelos motivos que já apontamos, a facilidade de acesso a um custo reduzido de tempo, já que tudo (trabalho, lazer, comércio, enfim) está tão próximo. É possível notar que as determinantes utilizadas pela mídia para induzir o comprador a adquirir uma propriedade na região granjeira, ou seja, o verde, está presente nas propriedades das áreas centrais também, o paisagismo, o requinte, o espaçoso e o belo estão tão presentes quanto nos 
condomínios da região metropolitana, a segurança que é um apelo forte, também está assegurada, pois, como já foi mencionado um dos critérios de busca no site, foi que a casa estivesse num condomínio, inclusive a mesma segurança oferecida na região granjeira, por meio dos muros, portarias e vigias.

A única e larga diferença entre os anúncios oferecidos, além do valor de troca dos imóveis, é óbvio, é o tamanho da área oferecida, isto é uma disparidade, além dos imóveis, aparentemente muito bonitos e luxuosos, terem valores diferentes entre si, o tamanho da área apresenta uma disparidade ímpar. Considerando os anúncios, enquanto no Jardim Paulistano há um imóvel com uma área de $689 \mathrm{~m}^{2}$ por $\mathrm{R} \$$ 3.200.000,00, no Morumbi há um outro cuja área é de $1.100 \mathrm{~m}^{2}$ por $\mathrm{R} \$ 4.300 .000,00$, e em Cotia na Granja Viana encontramos imóveis com área de $5.655 \mathrm{~m}^{2}$ (o proprietário pode manter uma "área de preservação permanente particular" se assim o desejar) por um valor que se comparado aos outros (levando em consideração a área) poderíamos dizer que "pela bagatela" de $\mathrm{R} \$ 1.200 .000,00$.

Esta cifra está muito além do que qualquer trabalhador assalariado poderia pensar ao comprar uma casa, é até por este motivo que a população cotiana vê os granjeiros como a verdadeira nata da "burguesia". Existe um distanciamento muito grande entre os granjeiros e os cotianos, no dia-a-dia parece até que as pessoas não tomam conta de que os granjeiros também são cotianos, sendo que todos são munícipes (todos pagadores de impostos) e, portanto, o respeito deveria ser o mesmo.

Os moradores da região granjeira sem dúvida estão pagando um valor para morarem na região que não é pago em nenhuma outra região de Cotia. Aliás, existe uma camada social de São Paulo de baixo poder aquisitivo que também saiu de São Paulo (foi expulsa pelas transformações da modernidade dos espaços que ocupavam); uma fração desta população teve como comprar um "pedacinho de chão" em Cotia também por um valor infinitamente menor $\left(250 \mathrm{~m}^{2}\right.$ de área total, com casa de três cômodos e banheiro construídos e acabados por dentro no valor aproximado de R\$ $31.000,00$ ), nas áreas de perfil topográfico bem acidentado e com pouca infra-estrutura na região central e de Caucaia do Alto. 
No entanto, ao observarmos os anúncios verificamos que para parcela dos moradores da cidade de São Paulo que acharam por bem vir morar na Granja Viana, mas que possuem uma vida profissional e social bastante ativa em São Paulo, seria incoerente a idéia de se afastarem tanto do seu "centro" de convivência (seja ela profissional ou lazer) se os argumentos utilizados por esses moradores para justificarem sua vinda para a Granja se limitassem a questão da qualidade de vida já que vários dos atributos da Granja são facilmente observáveis nos condomínios dos bairros nobres da cidade de São Paulo. Nesse sentido a "escolha" da qualidade de vida não pode ser dissociada das possibilidades financeiras que são, sem dúvida, preponderantes na escolha da Granja Viana e não do Morumbi, por exemplo.

Como CARLOS (2001:37) também constatamos

... que as transformações ocorridas na metrópole paulista apontam uma tendência, manifesta na prática socioespacial, segundo a qual os espaços se reproduzem cada vez mais em função das estratégias imobiliárias, e com isso limitam as condições e as possibilidades de uso do espaço pelos habitantes; isto é, cada vez mais os espaços urbanos, transformados em mercadoria, são destinados à troca, o que significa que a apropriação e os modos de uso tendem a se subordinar (cada vez mais) ao mercado...

As estratégias imobiliárias da capital paulistana por uma questão de raridade espacial, ou seja, a metrópole carrega no valor de uso e troca do seu espaço a excelência espacial em termos de localização (os espaços centrais estão muito próximos ao mercado que supre as necessidades) e infra-estrutura, por este motivo, a nosso ver, só consome o espaço quem realmente tem muito dinheiro para isso, a aquisição e a manutenção são igualmente muito caras.

As pessoas de uma classe social com bom poder aquisitivo procuram obviamente manter seu status e mesmo se o dinheiro para pagar uma casa no Morumbi não é o bastante, pode manter seu padrão de vida indo morar na Granja Viana, região mais cara do município de Cotia, tão próximo da cidade São Paulo. É interessante que os moradores procuram sustentar para todos, que o vir morar na Granja foi motivado pela qualidade ambiental que ela pode oferecer, ou seja, utilizam o discurso da propaganda que é feita sobre essa área. 
É justamente por meio deste tipo de apelo que os condomínios e bolsões residenciais da Granja Viana tornaram-se uma excelente opção para àqueles que com relativos "parcos recursos financeiros ${ }^{11 "}$ queriam "fugir" da metrópole paulista em busca de uma vida alternativa, ainda que muitas vezes a prioridade seja a de resguardar a segurança. O valor do solo e dos imóveis da Granja (que é alto em relação ao restante da cidade cotiana, mas muito mais baixo que alguns lugares da cidade de São Paulo e região metropolitana) é relativamente acessível às certas camadas sociais paulistanas que incorporam estrategicamente um discurso ligados à natureza e a elementos que podem garantir a "satisfação" e "felicidade pessoal e familiar", impulsionando o mercado imobiliário granjeiro.

Afinal, "... a alienação urbana envolve e perpetua todas as alienações. Nela, por ela, a segregação generaliza-se: por classe, bairro... Nela o espaço torna-se raro: bem valioso luxo e privilégio mantidos e conservados..." (LEFEBVRE, 1999:89). O espaço granjeiro é bem definido como a região "mais ilustre" de Cotia, havendo um consenso, construído na vida cotidiana, entre os cotianos.

Se voltarmos ao discurso utilizado pela propaganda na tentativa de valorizar o espaço granjeiro podemos capturar algumas das ideologias criadas e utilizadas para estabelecer a alienação urbana. Estamos aqui tentando apresentar a esfera global, indicando processos que se dão em escala mundial e que, de alguma forma, interferem no local, que embora guarde suas particularidades, também interfere e é interferido pelas ocorrências da esfera maior.

Temos a constituição de raridades, que como o próprio termo nos faz pensar, é uma categoria utilizada para tudo aquilo que não temos em abundância e é justamente por este motivo que há um valor simbólico agregado aos valores de uso e de troca também.

Ainda a respeito de centro-periferia, mas não mais na perspectiva da metrópole e sua região metropolitana, mas a respeito da própria Granja Viana como centro, não só residencial dirigido para uma única classe social, como de lazer igualmente destinado a uma única classe, mas um centro urbanizado que passa a ter algumas características

\footnotetext{
${ }^{11}$ Se comparados com as camadas de altíssimo poder aquisitivo.
} 
muito próximas a metrópole paulistana, e que, por este motivo, acaba se tornando centro de referência para o próprio município de Cotia.

As estruturas? São igualmente duplas: morfológicas (sítios e situações, imóveis, ruas e praças, monumentos, vizinhança e bairro) e sociológicas (distribuição da população, idades e sexos, famílias, população ativa ou passiva, categorias ditas sócio profissionais, dirigentes e dirigidos). (LEFEBVRE, 2002: 109)

Os moradores da Granja Viana, por meio de influência política e econômica conseguiram prover a região de estruturas que de acordo com LEFEBVRE são morfológicas e sociológicas, ou seja, a paisagem urbana local fala por si só (ainda que tenhamos que compreendê-las). É na Granja que encontramos os comércios e prestadores de serviços que geralmente encontramos em São Paulo, as concessões e franchise das lojas mais visitadas pelos paulistanos estão já a aproximadamente uns quarenta anos se fixando na malha urbana granjeira, desde comércios e serviços "mais populares" como Mc Donald's ou Habib's até os mais "requintados" como o Soho ou a Cultura Inglesa. Esse aparato todo exerce uma influência muito forte no estabelecimento dos freqüentadores desse centro comercial.

O estilo metropolitano de ser, incorporado pela região granjeira, traduz um modo de viver e consumir que não é encontrado em nenhuma outra região cotiana. Aliás, no centro de consumo granjeiro constituem os signos da auto segregação. Se considerarmos que

Os signos do urbano são os signos da reunião: as coisas que permitem a reunião (a rua, pedra, asfalto, calçada etc.) e as estipulações da reunião (praças, luzes, etc.)...a acumulação simultânea das riquezas e dos signos..."(LEFEBVRE, 2002: 111).

Os granjeiros normalmente repetem o discurso que o mercado utilizou-se para "legitimar" a sua opção em morar na região granjeira, no entanto, aos poucos vão "importando" todo modo de vida metropolitano que conseguem para a região. O fato é que as construções, os mercados, os estacionamentos, os seguranças, os códigos, os símbolos e os signos embutidos nos centros comerciais granjeiros desencorajam a "visita" de qualquer outro que não seja granjeiro à Granja.

Retomando o parágrafo anterior, aqui cabe uma ressalva, os centros comerciais granjeiros, os "point" da Granja também são visitados por pessoas que não sejam da 
região granjeira, desde que pertençam ou pareçam pertencer à mesma classe social: de preferência que os filhos estudem no Colégio Rio Branco e que as férias sejam para visitar a Disney ou Miami. Assim, os códigos são compartilhados pelos pares, e então os moradores dos condomínios ou bolsões residenciais destinados à classe média alta localizados na região central ou de Caucaia do Alto de Cotia, também participam dos encontros granjeiros.

Está implícito que só quem pertence à "nata" econômica da região é que pode freqüentar àqueles espaços, seja pelo alto preço da mercadoria, pela forma como as pessoas se vestem (roupas de grifes ou importadas o que faz notar qualquer um que não esteja vestido à altura), a forma como se comportam ou até mesmo o carro que você acessa o espaço (mesmo havendo um ponto de ônibus praticamente na porta dos estabelecimentos - como é o caso do centro de consumo na paralela à rodovia Raposo Tavares).

É possível notar que

...os usos da rua se determinam por relações espaço-temporais cada vez mais submetidos à lógica produtivista que transforma o tempo em medida, uma quantidade abstrata, e o espaço em uma distância a ser percorrida. A rua tende na metrópole a desaparecer, preenchida por carros; destinada à locomoção, torna-se inútil à vida social, que se deteriora à medida que os indivíduos privilegiam a vida privada em detrimento da coletiva não como opção livre, mas como coação pelo processo de reprodução do espaço urbano...As ruas, transformadas em lugares de comércio, pontuadas por vitrines ou ocupadas pelo comércio ambulante, reorientam os passos e marcam o emprego do tempo na metrópole. (CARLOS, 2001: 240).

Embora a autora esteja analisando um efeito dado na metrópole, o mesmo acontece nos centros de consumo da Granja, é possível perceber que as ruas são dominadas pelos comércios e prestadores de serviços, o acesso é feito por carros (salvo as empregadas domésticas, porteiros, jardineiros e afins, que transitam pelas ruas - alguns andam literalmente na rua, pois não existem calçadas, é como se não existe a necessidade dos "passeios" já que os moradores acessam de carro), os encontros que dão vida ao "vivido" e ao "urbano" são predeterminados nos lugares de prestígio granjeiro e são sempre os mesmos. 
A possibilidade de encontrar o diferente na rua é reduzido ao máximo possível, primeiro porque os moradores de outras regiões passam por lá sempre de transporte coletivo (para ir ou retornar do trabalho), um ou outro aventureiro que queira "visitar" o espaço "vip" granjeiro tem que dispor de um valor razoável de dinheiro no bolso e ter uma boa "indumentária", caso contrário estará fadado à compulsiva solidão. Segundo que o transporte dos granjeiros é realizado por meio de carros, é muito difícil encontrar um granjeiro da "ala nobre" andando a pé, mesmo que fazendo caminhada (este é realizado em lugares apropriados para não ter sua segurança em risco).

Os centros de consumo granjeiros são muito próximos uns dos outros, os minutos separam os condomínios e bolsões residenciais dos restaurantes, cabeleireiros e colégios, tudo é muito próximo e quase todos os aparatos comerciais estão do mesmo lado da rodovia Raposo Tavares, do lado da Granja antiga e mais rica certamente, o tempo é sempre "economizado", o acesso é rápido e o encontro é efêmero.

É como se "... A relação entre o habitante e a cidade é atravessada por modos de apropriação e usos envolvendo uma multiplicidade..." (CARLOS, 2001:40), os granjeiros se apropriam e usam o espaço compartimentado e não há o encontro com o diferente. A relação estabelecida pelo valor de troca enquanto intermediário da relação habitante - cidade é muito mais forte do que a dimensão vivida do urbano. A vida urbana, a cidade, o habitante e o cidadão, a interlocução entre esses é conturbada pelo mercado, o estilo de vida é permeado pelo "status". 


\section{Capítulo II. Tem briga na Granja: quem canta de galo?}

O espaço granjeiro produzido tornou-se irresistível no mercado (em especial para as camadas de média e alta renda). Ele é mais do que um "lugar bom para morar": Ele oferece status, e é justamente esta situação - o da obra transformada em produto - que produz uma outra frágil divisão entre os granjeiros. Esta divisão não diz respeito as diferentes classes sociais que convivem na mesma região em espaços fragmentados como já dissemos, até porque muitos granjeiros parecem desconhecer por completo a existência da face pobre granjeira (ela existe e trataremos disso no próximo capítulo). Estamos dizendo agora de uma divisão na mesma classe social, ou seja, há uma evidente insatisfação dos granjeiros tradicionais com a chegada dos novos granjeiros. ${ }^{12}$

Desde 1.940 a Granja vem paulatinamente crescendo, a fazenda partilhada por seu dono, Sr. Niso Viana, inicialmente uma parte destinada aos amigos rotarianos, depois aos operários (que formam os bairros populares do Parque São George e muito depois parcelada como parte dos "negócios imobiliários". Esse foi o movimento inicial de um processo que, paulatinamente, fez com que a região granjeira se tornasse a região mais importante (do ponto de vista imobiliário) do município.

As transformações foram acontecendo de modo acelerado: a fazenda de gado foi parcelada e as atividades foram se diversificando; o que servia só para produção hortigranjeira, começou a ser utilizado para finalidade de moradia - com propriedades destinadas para casas de veraneio formando bairros nobres que posteriormente deram origem aos bolsões e condomínios residenciais de médio e alto padrão, assim como pequenas propriedades destinadas aos operários, essas deram origem aos bairros populares como o Jardim da Glória e o Parque São George. Depois o espaço ganhou a CAC como ponto culminante de áurea época de Cotia agricultora (inclusive na própria Granja Viana); logo depois veio o período da industrialização do município formando

\footnotetext{
${ }^{12}$ Os granjeiros tradicionais chamam os novos granjeiros de "granjolas". Mais do que uma tentativa de ridicularizá-los é uma posição de protesto por aqueles considerarem que estes novos moradores procuram somente o "status" que a "grife" Granja Viana promove e não a "qualidade de vida" que a região pode oferecer (nesse sentido o discurso ecológico é incorporado em várias estratégias de valorização e manutenção dos espaços) e esta posição denota um comportamento diferenciado entre os novos moradores e os moradores tradicionais da Granja.
} 
seus bolsões no entorno da rodovia Raposo Tavares, sendo então estruturado os centros de comércios e prestadores de serviços de excelência.

A mídia e o marketing foram os veículos que mais divulgaram a região em ascensão, cuja proximidade a São Paulo capital e o equilíbrio ambiental foram os aspectos deram maior visibilidade a esse espaço - embora tenhamos compreendido pela pesquisa, como demonstraremos adiante, que o fator econômico foi preponderante na escolha da Granja Viana como lugar para morar por parte das pessoas que saíram de São Paulo e vieram para a região granjeira - é a região "gigante"13 pela força do mercado.

Os cotianos têm seus olhos curiosos voltados para uma Granja Viana de fartura, poder, "status", bom gosto e singularidade local enquanto a municipalidade restringe este olhar ao fator econômico que a região representa. Muitos paulistanos vêem a Granja como um pequeno paraíso e outros como um lugar onde existe a possibilidade de capitalizar. São vários olhares sobre uma região tão plástica, no sentido de flexibilidade, como um lugar capaz de mostrar tantas realidades quanto a capacidade de percebê-las.

O espaço da Granja Viana nos leva a grandes indagações, e, ao mesmo tempo se apresenta como uma região, constituída por fragmentos de estruturas no espaço. Trata-se de um espaço em que as pessoas estão produzindo e consumindo. Há uma multiplicidade de relações, de diferenças na igualdade ou igualdade nas diferenças, ao mesmo tempo pode ser uma promessa, de conseguir alcançar a vida urbana.

A configuração do espaço granjeiro nobre foi iniciado pelos loteamentos que se configuravam aleatoriamente (não havia nada predeterminado quanto aos tamanhos dos lotes/propriedades ou o padrão e estilo das casas a ser seguidos), para atender uma procura que era cada vez mais crescente em meados da década de 1980. Estas propriedades não estavam encerradas por um muro, elas constituam as ruas e quadras, como um bairro qualquer, com o passar do tempo alguns moradores de determinadas ruas, lançavam a idéia e pleiteavam junto à prefeitura muros que fechassem algumas

\footnotetext{
${ }^{13}$ Alusão ao hino nacional "...gigante pela própria natureza...", o município de Cotia tem na região da Granja Viana um "...gigante pela natureza do mercado...".
} 
ruas de uma, duas ou três quadras de forma que fosse possível "restringir o acesso de estranhos ao espaço formando desta forma os primeiros "bolsões residenciais".

Estes espaços acabaram sendo denominados pelo "marketing" imobiliário como "condomínios fechados", e esta condição valorizava ainda mais o espaço encerrado por muros e controlado por uma guarita. Os moradores assimilaram a idéia de todos morarem em condomínios no espaço da Granja, e por este motivo é muito comum ouvir os granjeiros ${ }^{14}$ dizerem que moram num condomínio. Entretanto, de acordo com a classificação da administração municipal, até o ano de 2.005 somente dois de todos os "loteamentos" realizados na Granja eram de fato "Condomínios Fechados". Hoje mais de vinte loteamentos já estão normatizados pelo município de Cotia como Condomínios Fechados. A lei faz uma distinção entre condomínios fechados reconhecidos como "Condomínios de Direito" daqueles outros espaços cujo acesso é restringido por guaritas chamados loteamentos abertos ou fechados (que configura a maior parte da Granja Viana), reconhecidos pela doutrina moderna como "Condomínios Atípicos". Esta distinção nos é muito valiosa para justificarmos o fato de que mesmo a Prefeitura do Município de Cotia reconhecendo apenas vinte loteamentos enquanto condomínios (“Condomínio de Direito"), a mídia e o mercado imobiliário trabalham (e vendem) a idéia de que a maior parte dos loteamentos residenciais da região é de condomínios.

Embora haja estas duas situações, a de Condomínio de Direito e Atípico, a realidade granjeira ainda não era atendida, pois havia muitos bolsões residenciais ruas com casas construídas e que tinham guaritas construídas em lugares estratégicos de acesso - que não tinham qualquer padrão para conseguir sua inscrição enquanto "condomínio" mesmo que "atípico", mas que desejavam gozar da segurança que só os condomínios conseguiam garantir aos seus condôminos. Desta forma a Câmara da cidade criou a Lei 694 de 08/11/1994, que atendia esta parcela da população com o aporte jurídico necessário para a criação dos "bolsões residenciais", sancionando diretrizes básicas para a criação dos bolsões, e desde então no

\footnotetext{
${ }^{14}$ Com a finalidade de não provocarmos confusão no leitor, vamos de hora em diante estabelecer algumas nomenclaturas para distinguir a população da Granja Viana. Quando dissermos dos 'granjeiros' estamos nos referindo à todos os moradores da região da Granja Viana sem qualquer distinção, quando dissermos dos 'granjeiros tradicionais', estamos nos referindo aos moradores dos loteamentos mais antigos da região e quando dissermos dos 'granjolas', estamos nos referindo aos moradores dos novos loteamentos da região.
} 
Artigo $1^{\circ}$. - Fica o Poder Executivo autorizado a criar "bolsões residenciais" nas áreas urbanas e com características urbanas, cujos projetos serão definidos por decreto, observando a melhoria da segurança individual e coletiva e da qualidade de vida dos moradores.

A criação dos "bolsões residenciais" é uma prática vivenciada até os dias de hoje na Granja Viana, e nem sempre esta prática é de comum acordo entre os moradores "beneficiados" pela construção do muro e a população do entorno.Temos um exemplo muito recente que ilustra bem esta situação: no Km 23 da rodovia Raposo Tavares foi construído um muro caracterizando o "fechamento" da Rua Nova Lima e os moradores do entorno (Rua Padre Matheus de Lara João) não aprovaram a decisão. Parte dos moradores se manifestou contra apontando a questão da acessibilidade como um prejuízo aos moradores como podemos ver no depoimento abaixo:

As alternativas são de difícil acesso. Uma paralela está cheia de buracos e a outra é muito estreita. A rua Nova Lima é a única asfaltada...uma minoria não pode prejudicar a todos, esta rua é fundamental. (Jornal D'Aqui, 2006:05).

Uma outra parte da população, neste caso de proprietários de apenas doze casas da rua fechada pelo muro, argumentavam que

Há vinte anos lutamos pela segurança. Fiquei mais de um ano na prefeitura tentando fechar esta rua. (Jornal d'Aqui, 2.006:5).

Ainda neste sentido, seguindo a Estrada do Embú, encontramos um outro caso parecido onde uma via pública é fechada por uma guarita para resguardar a segurança dos moradores local, o acesso é bem restrito e mesmo não sendo condomínio, seguem o mesmo padrão de segurança, conforme podemos observar na foto a seguir existem casas que não foram "contempladas" pela guarita, segundo os moradores que não estão dentro do "bolsão", “... a rua é pública e só passa nesta rua quem mora aqui, não precisa disso tudo não..." 


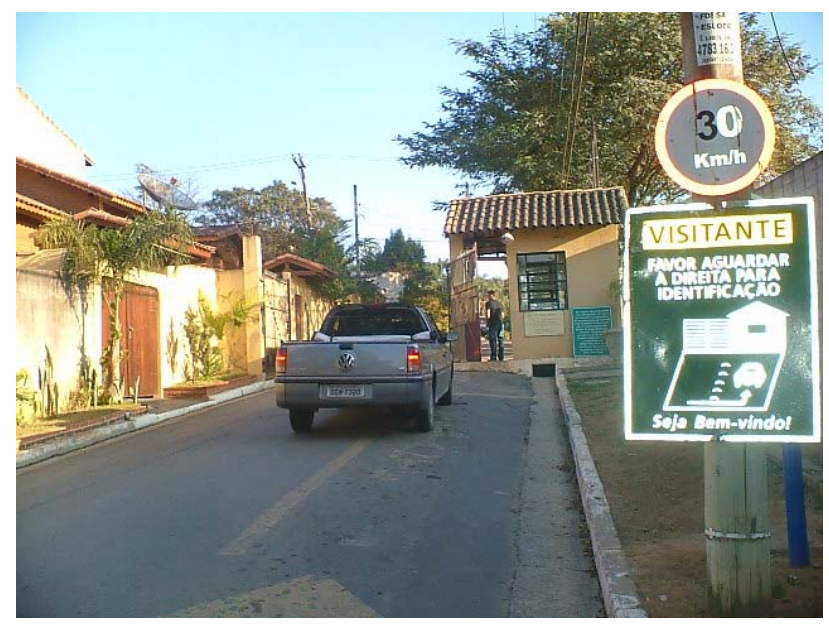

Trivelato, Ana C. Junho/2006.

Rua das Magnólias - Granja Viana

Assim, os bolsões vão sendo constituídos e vão se prescrevendo no espaço granjeiro junto com os loteamentos abertos e fechados (Condomínios Atípicos) e os próprios Condomínios (Condomínios de direito), e as discussões e brigas por acesso e segurança vão dando o panorama de contradição permanente entre a população.

A tendência em fechar as ruas em nome da segurança criando desta forma os bolsões está cada vez maior, e os conflitos tem sido cada vez mais constantes e levados ao conhecimento de instâncias administrativas de órgãos maiores que o municipal, vejamos o seguinte artigo publicado pelo Jornal D' Aqui (2a Quinzena de Junho de 2006:05)

Ministério Público tem prioridade contra fechamento de ruas.

O Procurador Geral de Justiça do Estado de São Paulo - promotor Rodrigo Cezar Pinho - assinou ato normativo n 418 (em fevereiro de 2006) que estabelece o plano geral de atuação do Ministério Público do Estado de São Paulo para 2006. Entre as prioridades estão o combate à ocupação e uso irregular de áreas públicas: fechamento de ruas e autorizações, permissões e concessões de espaços públicos. Diz o ato "As áreas verdes e institucionais e vias de circulação e outros bens de consumo do povo são bens imóveis de domínio público, que desempenham papel essencial na administração do uso e da ocupação do solo urbano do Município. Neste sentido, a Constituição do Estado de São Paulo, em seu artigo 180, inciso VII, determina que tais áreas, não poderão ter seus fins e destinação alterados. Tais regras de regência visam preservar o bem comum, muitas vezes atingido em razão da indevida apropriação privada dessas áreas, o que se dá 
por exemplo, com o fechamento de ruas, concessões e permissões de uso ilegalmente estabelecidas"...

Muitos dos atuais bolsões não eram assim denominados quando do loteamento das áreas. Eles só foram estabelecidos quando os lotes ainda estavam sendo vendidos, gerando a possibilidade formal de sua criação por meio do surgimento de um certo tipo de espírito de "condôminos" entre os moradores (salvo quando existem moradores muito antigos no local e o "bolsão" o agrega sem que este morador queira pertencer a este, gerando nesta situação também muitos conflitos, principalmente quando do pagamento de taxas para a manutenção da guarita ou segurança).

Esta diferenciação de "Bolsões Residenciais" para "Condomínios" na prática vai fazer diferença em apenas dois aspectos: o primeiro é que um "bolsão residencial" não poderia sequer pedir para um "desconhecido" se identificar ou dizer porque quer entrar no local - o acesso não pode ser restringido sob hipótese alguma (estamos dizendo "poderia", porque na prática todos impedem o acesso de estranhos ao local), e o segundo aspecto fica por conta da não determinação específica de tamanhos de lotes e/ou estilos da casa (tamanho, material a ser utilizado, uso de cercas e muros internos ou não e coisas desta natureza) em tratando-se de "bolsões" residenciais.

Independentemente de termos "bolsões residenciais" ou "condomínios" na Granja Viana, o interessante é que a região granjeira só pode ser entendida se analisada na sua diferença, na contradição das relações num mesmo espaço, e é este o nosso propósito, olhar a Granja de dentro e não de fora como sempre fazemos, não seremos o passageiro que passa pela Granja ao trafegar pela rodovia Raposo Tavares, porque este geralmente vê uma Granja igual sem diferenças ou diferentes.

Sabemos dos muito diferentes que constituem a região granjeira, mas é da diferença entre os mesmos que gostaríamos poder entender, capturar os elementos e os processos que estabeleceram tal diferença. Perceber as contradições entre os aparentemente iguais nos parece ser o mesmo, metaforicamente falando, que olhar pela fechadura da porta cerrada de uma grande reunião em que você não foi convidado e conseguir desvendar alguns dos segredos que não se apresentam para a sociedade como um todo. 
Existe como mostraremos conflitos na chamada Granja nobre, mas há em comum, apesar dos conflitos uma relação capaz de unir os fragmentos que constituem a Granja: todos querem manter o "status" que a região possui, o espaço de excelência precisa ser preservado, até para que continue sendo valorizado. Nesse sentido há uma articulação entre o mercado imobiliário, a ação municipal e um esforço muitas vezes pessoal dos próprios moradores para que assim seja.

Vamos, neste capítulo, nos concentrar na população granjeira que possui maior influência política e financeira. São os moradores dos bolsões e condomínios residenciais de médio e grande porte, todos eles procuram de alguma forma manter o valor de seu patrimônio. O que nos parece muito interessante é que embora o objetivo seja único, as estratégias são diferentes.

Percebemos que na região da Granja Viana nobres têm uma distinção entre seus moradores: de um lado encontramos os granjeiros mais antigos, a maioria está morando na região à mais de cinqüenta anos e viram o lugar onde moram sendo construído, são capazes de contar atreladas à sua própria história a história de onde mora, dizendo nomes de vizinhos, comentando particularidades, são de uma época em que a Granja Viana era conhecida e valorizada, mas não tinha todos os atrativos comerciais que tem hoje e muito menos uma dimensão populacional tão adensada, percebida pelo aumento do número de "portarias" que, aos poucos, vão ocupando os espaços que antes eram preenchidos por matas.

Esses granjeiros mais antigos são considerados os tradicionais, vieram assim como os demais buscando uma vida mais sossegada (de campo), longe da "bagunça" paulistana. $O$ valor da terra também foi considerado, já que a maioria adquiriu não apenas um "lote" grande para construir sua casa, mas verdadeiros sítios, arborizados, onde cultivaram com plantações (de subsistência por uns na época de uma Cotia agrícola, de consumo para outros que queriam apenas o prazer de comer algo que cresceu em sua terra), fizeram uma boa casa, área para recreação, casa para o caseiro e ainda um "bosque" a perder de vista, tudo isto cercado por árvores, a cerca viva mas imóvel, demarcava um espaço . 
A vida era, segundo entrevistas com moradores mais antigos, mais difíceis: os granjeiros tinham como única opção, na época, para efetivarem suas compras realizarem suas horas de lazer ou manter sua vida social fazerem o deslocamento para a grande cidade, São Paulo. Além disso, as ruas de servidão e vicinais não eram asfaltadas, a mata era muito mais protuberante que atualmente, o número de vizinhos era muito menor, a segurança daquela época era muito boa mesmo não havendo portarias ou seguranças pagos para fazerem a vigília, havia maior rusticidade no modo de viver. Não que não houvesse as comodidades: os granjeiros andavam com seus carros importados e equipados em ruas cujos cascalhos e britas faziam o cortejo que estimulavam permanentemente o espírito de aventura do morador.

O setor imobiliário da região, até então era oferecida e procurada sem muitos estímulos do município, até porque até uma determinada época o poder municipal de Cotia tinha as indústrias como "a menina dos olhos". Com a franca expansão do mercado imobiliário nesse segmento (o industrial), esse processo não poderia deixar de constar nos documentos oficiais da cidade, então:

Há que considerar, porém, que, se a atividade do setor secundário mostra alta capacidade de multiplicação, sua implantação em larga escala em Cotia surge como pouco provável, face à ausência, no Município, de maiores ofertas de fatores locacionais competitivos com os demais Municípios da Região.

O provimento de espaço e localização habitacional sob a forma de parcelamento deverá prosseguir como atividade de significativa, posto que incentivado pela recorrência da inflação e por sua posição privilegiada como reserva de investimento, face à baixa competitividade das demais aplicações disponíveis, e diante das dificuldades de espaço dos municípios vizinhos, com maior vocação para atividades industriais e loteamentos populares. (Lei Complementar 001/91 - II. 5. Alternativas e Perspectivas para Cotia).

Assim, junto a expansão industrial incrementa-se o processo de loteamento de áreas voltadas para as classes mais abastadas da metrópole paulista. Para estes era apresentada a possibilidade de morar perto do verde, A vida rupestre granjeira passou a ser muitas vezes utilizada por meio do marketing imobiliário e apresentada como "a melhor opção de moradia para quem quer fugir da vida caótica de São Paulo" às 
pessoas que buscavam em agências imobiliárias moradias alternativas de alto e médio padrão; esse "jeito" de morar de "vida simples" inclusive agregava maior valor ao imóvel. Mas essa realidade foi mudando. Os novos vizinhos iam chegando, as necessidades eram basicamente às mesmas (momentos de lazer, comprar, consumir, ter uma vida social), mas um curioso movimento rompia as antigas relações e buscava uma aproximação maior de "pedaços" de São Paulo à região granjeira, era a força do mercado. Se antes privilegiava-se o deslocamento para satisfação das necessidades agora, num movimento diferente, "implanta-se em alguns pedaços da Granja espaços tão parecidos que por uma foto não saberíamos dizer se estávamos na Granja ou na Avenida Faria Lima, Vital Brasil ou outra rua de movimento paulistana.

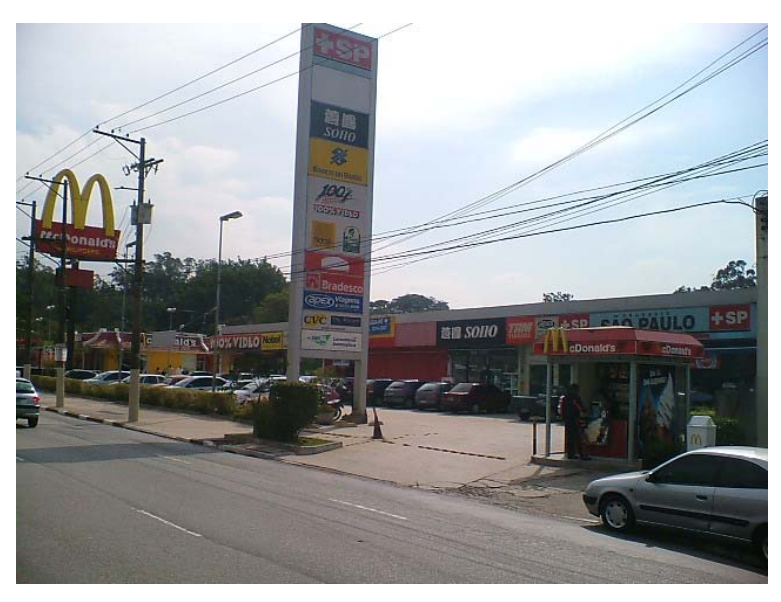

Trivelato, Ana C. (Junho/2006)

Av. Corifeu de Azevedo Marques

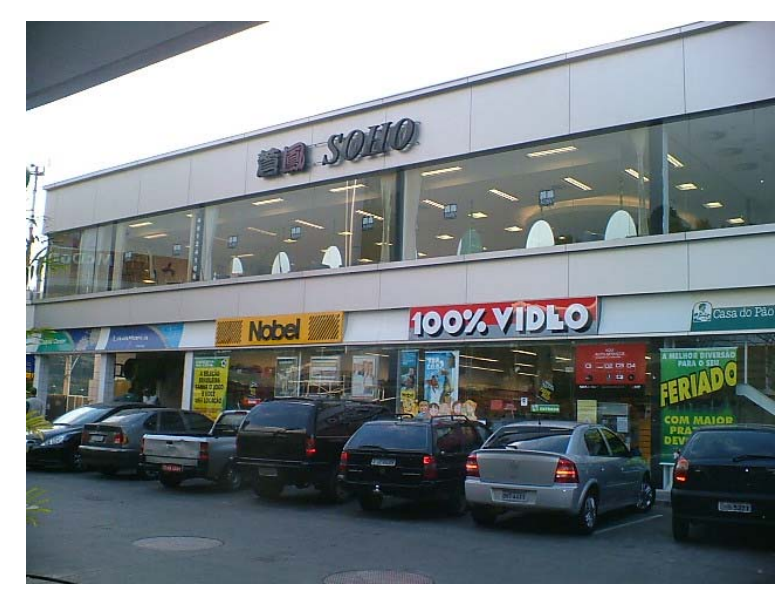

Trivelato, Karine Ap. (junho, 2006)

Boulevard rodovia Raposo Tavares

Quase tudo mudou, de repente

A região da Granja Viana, com seu pólo industrial e condomínios de médio e alto padrão, destaca-se por oferecer todas as finalidades de um centro urbano com a qualidade de vida que só Cotia pode oferecer. Ali se encontram atrativos como o Kartódromo Internacional, diversos ateliês de artistas plásticos, ceramistas, centro gastronômico diversificado, mini shoppings, etc...(Guia Turístico Oficial de Cotia, 07:2002/2003).

A paulatina chegada desses novos vizinhos foi preenchendo a região granjeira. No início o encontro da vida esperada ou a acomodação desses novos e primeiros vizinhos entrava em sintonia com o modo de viver preexistente, mas aos poucos foi inevitável a constituição de uma Granja de centros de consumo e serviços, "points", 
"nights" foi crescendo juntamente com o número de ruas asfaltadas, muros e portarias: o espaço estava cada vez mais agregando valor para ser consumido.

LEFEBVRE (2002:146/147), ao se propor a analisar as contradições do espaço urbano, ajuda a nos esclarecer quanto a produção do espaço da Granja, ou ainda, a racionalidade (ideo) lógica que regeu a sua produção, e desta forma

...O importante é sublinhar o papel do urbanismo e especialmente o do "imobiliário" (especulação, construção) na sociedade neocapitalista. O "imobiliário", como se diz, desempenha o papel de um segundo setor, de um circuito paralelo ao da produção industrial voltada para o mercado dos "bens" não-duráveis que os "imóveis"...Na medida em que o circuito principal, o da produção industrial corrente dos bens "mobiliários", arrefece seu impulso, os capitais serão investidos no segundo setor, o imobiliário. Pode até acontecer que a especulação fundiária se transforme na fonte principal, o lugar quase exclusivo de "formação de capital", isto é, de realização da mais-valia. Enquanto a parte da mais-valia global formada e realizada na indústria decresce, aumenta a parte da mais-valia formada e realizada na especulação e pela construção imobiliária. O segundo circuito suplanta o principal. De contingente, torna-se essencial...

As "melhorias" granjeiras foram sendo feitas com a ajuda do poder público e também por iniciativa privada (normatização, asfalto, iluminação pública, água, esgoto, enfim), mas foi com o capital privado que os centros de consumo e lazer foram sendo construídos (hípica quadra de golfe, tênis, autódromo, boulevard e outros). Havia uma franca intenção em "fazer" a Granja Viana "irresistível": ela passaria a ter o "verde" ofertado junto às condições otimizadas de relações sociais, consumo e lazer.

Os moradores novos da Granja Viana nobre ou como já dissemos, os granjolas, foram os que mais se organizaram politicamente e financeiramente para conseguirem esses espaços, talvez porque tivessem um capital disponível para ser aplicado em algum comércio comprando uma franquia na Granja ou acreditando na demanda granjeira na instalação de consultórios. O fato é que esses "granjolas" acabaram diminuindo o esteriótipo de "cidade dormitório" da Granja.

O adensamento da Granja, traduzido pela vinda dos granjolas, significou uma força que deu início - ou acelerou - o processo de modernização do espaço. Nenhum espaço está "protegido" da modernização, ainda mais quando ele é utilizado para a 
reprodução do capital. No caso há um movimento de modernização muito grande na região que vem levando a transformação de modo acelerado do espaço: alguns elementos que outrora eram motivo de preservação, como córregos, banhados, matas, foram sendo transformados: o córrego foi canalizado e o banhado foi aterrado para a construção do centro de consumo paralelo a rodovia Raposo Tavares.

A posição da maioria dos granjeiros antigos ou tradicionais foi de recusa àquele movimento. Hoje, há uma tentativa de "impedir" ou até "recuperar" os espaços "invadidos" nesse processo de modernização promovido pelos granjolas. Como exemplo podemos citar o caso do Sr. José Roberto Barreto Lins Filho, residente à Rua Dom Joaquim na Granja Viana que ao enviar uma solicitação de mudas ao Departamento de Meio Ambiente do município de Cotia em fevereiro de 2003, escreveu o seguinte:

Solicitamos as mudas para plantio primeiro porque somos amantes da natureza e já cuidamos de dezenas de árvores em nosso terreno na Granja Viana, onde moramos desde 1969. Mas existem mais duas razões especiais. Nossa casa é antiga, vem do tempo em que era comum fazer jardins à moda européia. Em decorrência, temos no terreno vários pinheiros e gostaríamos de dar mais diversidade às árvores colocando agora mudas de plantas da região. O terceiro motivo para requerermos as mudas é que a casa dá fundos para a Raposo Tavares, cujo barulho está cada dia mais insuportável. Não queremos nos desfazer da casa para que ela se torne um deserto construído, como aconteceu com o vizinho ao lado (que desmatou tudo para fazer uma loja de vendas de madeira rústica) ou com o brejo aterrado do $\mathrm{Km} \mathrm{24}$, onde fica agora o supermercado Pão de Açúcar. Nossa idéia é preservar o verde do terreno até o dia que fique realmente impossível de se viver lá, o que parece ser a triste e decadente sina de todo um pedaço da Granja Viana...

Embora o movimento de modernização espacial e o adensamento da Granja nobre seja um contínuo, os granjeiros tradicionais mais persistentes tentam, segundo eles às "duras penas", manter a Granja da forma como era (de matas e ruas de terra) mesmo que somente dentro dos limites de sua propriedade. Contraditoriamente, apesar de criticar o aparecimento dos novos serviços na área, muitas vezes usufruem os "benefícios" trazidos por este mesmo movimento. Mesmo que esporadicamente muitos dos granjeiros fazem compras no supermercado (no caso Pão de Açúcar), cuja 
construção exigiu o aterramento do banhado (suprimindo a fauna local e transformando a paisagem).

E curioso notar nas entrelinhas da mídia impressa e na fala de alguns moradores as insatisfações com os descontentamentos do dia-a-dia. Diferentemente da "imagem" que a Granja nobre apresenta, de paraíso, há uma "briga camuflada" entre os moradores: mesmo civilizadamente cada grupo de moradores sente a modernização de formas diferentes promovendo o que poderíamos chamar de disputa entre granjeiros e granjolas nesse espaço.

Os granjolas, ou parte deles vêem a público para dizerem o quão importante é o crescimento da Granja Viana, dando depoimentos que estimulam as mudanças como esta:

...Antes fazia minha vida em São Paulo, meus filhos estudavam por lá. Hoje existem opções de escolas, clínicas, restaurantes, serviços em geral que só utilizo aqui. Prefiro aproveitar a estrutura da região do que ir para São Paulo e pegar trânsito. (Revista Circuito de Informação, setembro/2003:15)

Já os granjeiros aparecem com um discurso bem diferente: há uma clara tentativa em sensibilizar as pessoas visando impedir que esse movimento continue, como é o caso do artigo publicado numa revista de grande expressão na região

O impacto e vizinhança, a degradação do meio ambiente, o descabido adensamento produzido pelo absurdo re-parcelamento do terreno original, a transformação para pior de um patrimônio coletivo que levou décadas de lutas, investimentos feitos com sacrifício para ser construído, nos assusta... (Jornal d'Aqui, janeiro/2004:07)

Não pretendemos analisar aqui se são os granjeiros tradicionais ou os granjolas os "donos da razão", o fato é que todos são granjeiros (moradores da região da Granja Viana) e certamente gostam do lugar onde moram ou ainda pretendem lutar para que o valor da 'sua' propriedade/imóvel continue em alta. O fator que gostaríamos de apontar é que ainda que os granjeiros tradicionais apontem os granjolas como os "culpados" por esta transformação (utilizado como "chamariz" para que mais pessoas venham morar na região) e por outro lado, embora os granjolas julguem os granjeiros tradicionais retrógrados como a "pedra que atrasa o desenvolvimento" local, a força que iniciou todo este processo está no mercado, pois 
O espaço tornado mercadoria, submetido às estratégias imobiliárias, voltadas às novas necessidades da reprodução, recria-se em função de objetivos específicos que fogem e se sobrepõem aos desejos dos habitantes, de modo coercitivo. Nesse processo, as pessoas se sentem desenraizadas e sem referenciais...(CARLOS, 2001:209)

As mudanças surgidas no espaço granjeiro não acontecem de fato por vontade deste ou daquele grupo de moradores. Evidentemente existe uma forma de induzir ou não alguns acontecimentos, mas a necessidade de reprodução do capital é muito mais forte do que o desejo dos habitantes de determinados locais, as pessoas tendem a se acostumar com algumas mudanças, em outros casos desejar que elas realmente aconteçam, mas o imperativo não é a vontade dos que moram no local que é realizado, o que prevalece é o mercado.

Embora em linhas gerais os granjeiros se coloquem como pessoas muito diferentes dos granjolas, em questão de comportamento e estilo de "morar", existe um ponto em comum enquanto posicionamento dos moradores da Granja nobre como um todo: o receio do acesso de todos à região da Granja Viana, a banalização espacial por meio da especulação e oferecimento da terra granjeira à uma classe não condizente com a região nobre, ou seja, existe um latente receio de que a Granja seja ofertada por um valor muito acessível à uma classe média distante da realidade dos moradores locais.

Enquanto a 'explosão imobiliária', como geralmente os documentos oficiais e os próprios granjeiros se referem aos espaços divididos e vendidos da Granja, se dá entre os mesmos, os conflitos vão acontecendo, mas as situações vão se atenuando. Diferentemente seria se houvesse uma "liquidação" do solo granjeiro e houvesse a chegada dos "não iguais" na região nobre, possibilidade esta que incomoda até os granjolas.

As pessoas têm que se certificar de que não vão correr o risco de encontrar alguém que não seja como ele. No Boulevard, por exemplo, existem algumas normas de conduta, vestimenta e etiqueta que acabaram se tornando verdadeiros códigos para alguém poder acessar determinados grupos ou ambientes. 
A chamada Granja nobre pode ser informalmente dividida em dois espaços distintos. Ainda que a região se destine às classes média e alta, podemos afirmar que temos espaços de "nobrezas" diferentes.

Existe um primeiro espaço onde estão concentrados os principais bolsões residenciais de médio e alto padrão: são os mais antigos e estão nas principais vias mais "antigas" da Granja Viana, sito a Av. José Félix de Oliveira, a Av. São Camilo, a Cherubina Vianna e outras próximas à estas, mas de menor importância como referência. Todas essas vias e suas transversais são consideradas pelos granjeiros como a Granja Viana Velha. Este espaço forma um "centro" localizado entre os Km $23 \mathrm{e}$ 24 da rodovia Raposo Tavares (sentido São Paulo - interior do lado direito).

O segundo espaço da Granja nobre, é informalmente chamado de Granja Viana nova. Esta é muito maior (em metros quadrados) do que a Velha. De acordo com o mapa que se segue (pág. $46 \mathrm{~A}$ ) esta área está pulverizada do $\mathrm{Km} 21$ ao 30 da rodovia Raposo Tavares (respeitando o "intervalo" respectivo à Granja Viana Velha), "atravessando" inclusive a própria rodovia (cabe aqui ressaltar que é comum identificar o "outro lado da rodovia" como Granja "pobre"). Esses espaços (da Granja Viana nova) também dão acesso aos condomínios de médio e alto padrão.

A Granja Viana nobre formalmente e mesmo administrativamente é um único espaço, ficando difícil entender, para os que são de fora, porque entre eles, existe a distinção acima assinalada. Para os cotianos, de forma geral, e para a administração pública não existe qualquer menção sobre tal distinção. Essa "separação" só pode ser atribuída à própria constituição do espaço granjeiro.

$\mathrm{Na}$ Granja Viana nobre (tanto a antiga quanto a nova), existem bolsões residenciais e condomínios de igual valor imobiliário (e, portanto com moradores de poder aquisitivos muito semelhantes entre si), esta divisão (antiga e nova) de certa forma também ajuda na identificação da população considerada granjeiros e granjolas. A partir de sua constituição ao longo do tempo é que conseguimos entender melhor a situação.

Nas décadas de 1970 e 1980 houve uma verdadeira expansão da região granjeira no mercado imobiliário devido grande procura: muitas áreas - que ainda eram cobertas por mata nativa ou em estágio de regeneração foram loteadas e vendidas aos 
"novos granjeiros", portanto podemos dizer por "dedução" que de certa forma os granjolas se encontram hoje na região da Granja Viana nova, ou na área de expansão da Granja. Um outro elemento importante de mencionar é que embora alguns bolsões ou condomínios residenciais sejam muito parecidos com os da Granja Viana velha, grande parte das propriedades desta Granja Viana nova possui uma área (em metros quadrados) menor do que as propriedades da Granja antiga.

Conversando com alguns granjeiros e consultando o setor de cadastro imobiliário de Cotia, constatamos a seguinte realidade: os lotes dos bolsões residenciais são divididos em tamanhos bastante diferenciados entre si, como já dissemos, não existe uma regularidade de tamanho de lotes, mesmo estes pertencendo a um mesmo bolsão.

Como exemplificação dessa situação podemos citar o caso do no Loteamento Granja Viana II (Glebas 04 e 05, em que a prefeitura ${ }^{15}$ queria aprovar um (re) parcelamento de solo baixando como "parcelamento mínimo dos lotes" de $500 \mathrm{~m}^{2}$ para $250 \mathrm{~m}^{2}$. Essa proposta causou insatisfação generalizada nos compradores, fazendo com que a prefeitura arquivasse o processo. Bem, é certo que os diferentes tamanhos dos lotes agregados a fatores como água, luz, iluminação e o "tipo" dos imóveis construídos no local (mansão ou casa de campo, casa de alvenaria ou de madeira e outros) vão determinar o valor dos lotes de um referido bolsão ou condomínio residencial, mas percebemos que há um outro fator que vai determinar o valor destes lotes no mercado imobiliário, a saber: a distância.

A rodovia Raposo Tavares é uma via expressa que, em nosso caso, é importante por ligar a cidade de São Paulo ao município cotiano. Esta estrada faz parte de uma grande de importante estrutura viária, que integra, por meio do Rodoanel Mário Covas, a rodovia dos Bandeirantes, a rodovia Castelo Branco e a rodovia Régis Bittencourt, a rodovia Raposo Tavares e, portanto a própria cidade paulistana, seu interior, o litoral e até mesmo outros Estados que são acessados num curto espaço de tempo.

$\overline{15}$ Isto se deu no de 1999 e começo de 2000. 


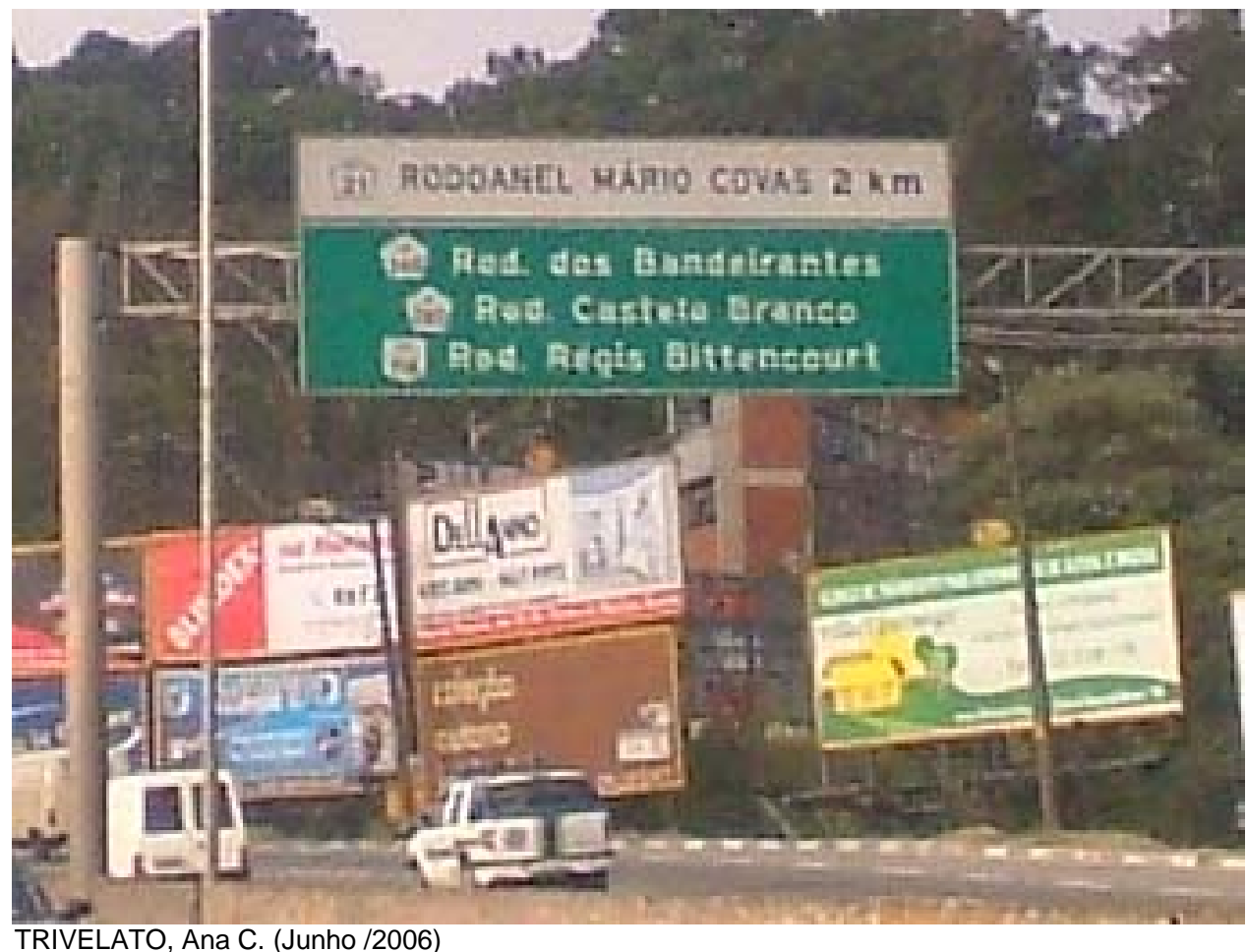

Foto da placa informativa da rodovia Raposo Tavares, na altura do $\mathrm{Km} \mathrm{23,5.}$

Estamos chamando atenção para a rodovia Raposo Tavares porque é nela que está, a nosso entender, uma das características que vão ser agregadas ao valor dos lotes granjeiros, que faz parte da mesma lógica da instalação das indústrias e do escoamento de matéria-prima e seus produtos para o centro, interior, porto ou ainda outros Estados. Muitos granjeiros mantêm sua vida profissional e social voltada para a cidade de São Paulo, então é possível entender o quão importante é uma via de acesso para a capital aos moradores da região granjeira e é justamente esta necessidade que foi cooptada e tornou-se estratégia de divisão e valorização das terras ali comercializadas.

Independentemente dos bolsões e condomínios residenciais estarem à direita ou à esquerda da rodovia Raposo Tavares (sentido São Paulo - Interior) na região da Granja Viana, os valores tendem a ser mais altos quanto mais próximos os bolsões e condomínios residenciais forem da rodovia ${ }^{16}$, e o contrário também é verdade, quanto

\footnotetext{
${ }^{16}$ Cabe ressaltar que quando dizemos da proximidade não necessariamente estamos dizendo na "beira" da rodovia, pois o ruído é uma condição que "desvalorizaria" o imóvel, portanto as distâncias aqui mencionadas são relativas, não estamos falando de uma distância percorrida a pé e sim de automóvel.
} 
mais distante ${ }^{17}$ os empreendimentos imobiliários forem da rodovia os lotes perdem um pouco do seu valor.

Percebemos como estratégia imobiliária o seguinte efeito: os lotes de uma parte dos empreendimentos imobiliários distantes da rodovia Raposo Tavares são maiores do que os lotes oferecidos na sua proximidade e o mais curioso é que o valor quase sempre é mantido igual. Obviamente os loteamentos próximos à rodovia são os mais procurados, então o mercado promoveu um "estímulo" para equilibrar a procura e garantir a expansão da região granjeira "nova".

A aparente "compensação" (pagar relativamente menos por áreas maiores por estarem mais distantes das vias de acessibilidade) faz parte da estratégia de expansão imobiliária na região granjeira, de modo a efetivar o processo reprodução do capital. Pensando na acessibilidade seria mais interessante morar em áreas nobres próximas à rodovia e, espontaneamente poucos granjeiros se aventurariam comprar em lugares muito distantes desta. Para estimular a venda das áreas distantes o mercado imobiliário oferecia uma alternativa aos possíveis compradores: a "venda de mais por menos". O famoso "leve dois pague um" muito utilizado nos supermercados para garantir uma boa vendagem de determinadas mercadorias, acontece na comercialização das terras também (resguardando as devidas proporções), a barganha e a "vantagem" em ter um lote maior ${ }^{18}$ pelo preço de um lote menor compensa o comprador pela distância a mais que terá que percorrer da sua casa até a rodovia.

Novamente temos uma interferência da reprodução do capital, ou seja, para o comprador talvez seja um investimento mais certo comprar uma área grande por um preço que (aparentemente) esteja Ihe dando "vantagem", então o comprador "vende" a comodidade de estar bem próximo à rodovia em troca de uma área de tamanho maior.

No momento em que esses granjeiros compram seu espaço na Granja Viana, a construção do imóvel passa a ser o grande desafio: engenheiros e arquitetos fazem os sonhos de muitas pessoas virarem realidade, muitas visitas ao local, passeios pelo

\footnotetext{
${ }^{17}$ Esta distância pode ser considerada como aqueles empreendimentos cuja proximidade com os limites da cidade de Cotia com os municípios vizinhos (direita da rodovia no sentido São Paulo - Interior: Barueri, e esquerda: Embú, por exemplo) é muito grande.

${ }^{18}$ As dimensões dadas aqui dos lotes granjeiros, como maior/menor ou grande/pequeno, está seguindo a seguinte proporção: estamos considerando nesta realidade lotes pequenos os menores de $1.500 \mathrm{~m}^{2} \mathrm{e}$ grandes os maiores de $2.000 \mathrm{~m}^{2}$.
} 
loteamento e as expectativas dos contratantes vão fermentando as "idéias" que resultarão em muito trabalho e dinheiro gasto na construção daquilo que melhor representa o granjeiro...sua casa.

Num mesmo bolsão residencial ou loteamento, como eles costumam dizer, encontramos vários estilos de casas que, aparentemente, conseguem refletir muito bem a condição financeira do seu proprietário. As diferenças entre os mesmos podem ser percebidas em cada rua, quadra ou quarteirões nos quais vemos o simples e o suntuoso despertarem as mais variadas impressões naqueles que podem acessar o espaço e observá-lo.

Encontramos uma outra forma de distinção entre os granjeiros tradicionais e os granjolas na apropriação de seus lotes. Os primeiros, os granjeiros tradicionais, construíram suas casas mantendo uma "certa" simplicidade: são casas grandes e confortáveis, mas que na maioria das vezes mantêm a "rusticidade" e o perfil de "casa do campo"; os granjeiros que vieram morar na Granja há aproximadamente uns dez anos atrás, construíram casas optando por uma arquitetura, uma transição entre os extremos "granjeiros tradicionais" e "granjolas": as casas são de alvenaria, grandes, confortáveis, mas com muita vegetação no entorno (percebe-se muitas vezes que nem houve trabalho paisagístico, apenas o bom senso do morador), e finalmente os granjolas, cujas casas são realmente cinematográficas, quase não há vegetação, salvo àquelas paisagisticamente permitidas, as casas são ostensivas e mesclam formas arrojadas à prepotência do estilo "americano de viver".

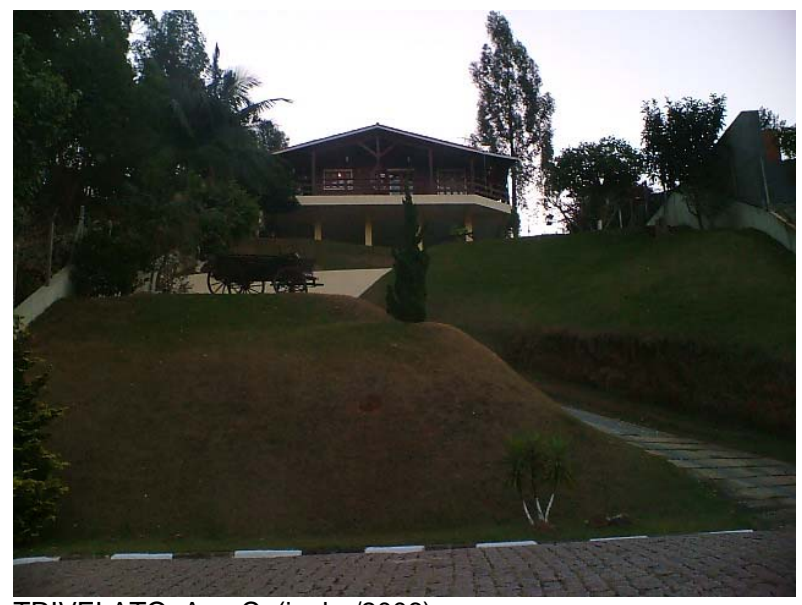

TRIVELATO, Ana C. (junho/2006)

Estilo de Casa Tradicional

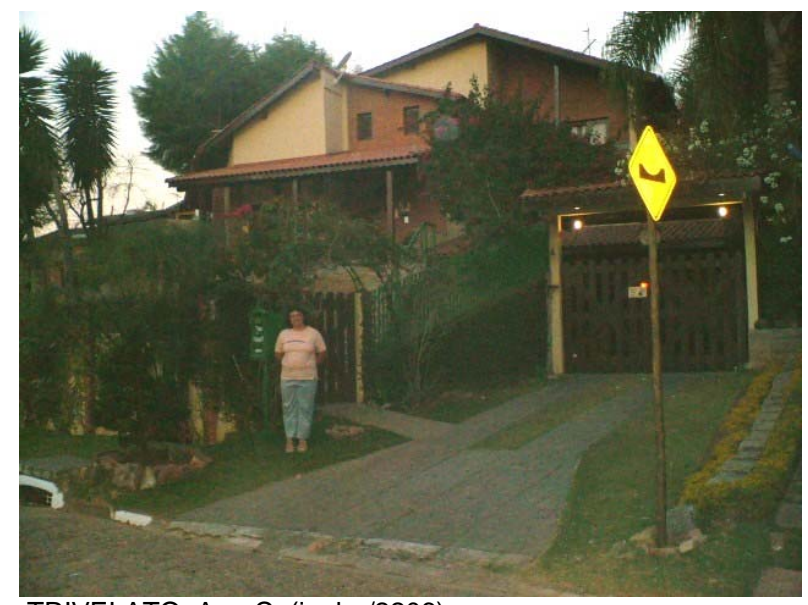

TRIVELATO, Ana C. (junho/2206) Estilo de Casa de Transição 


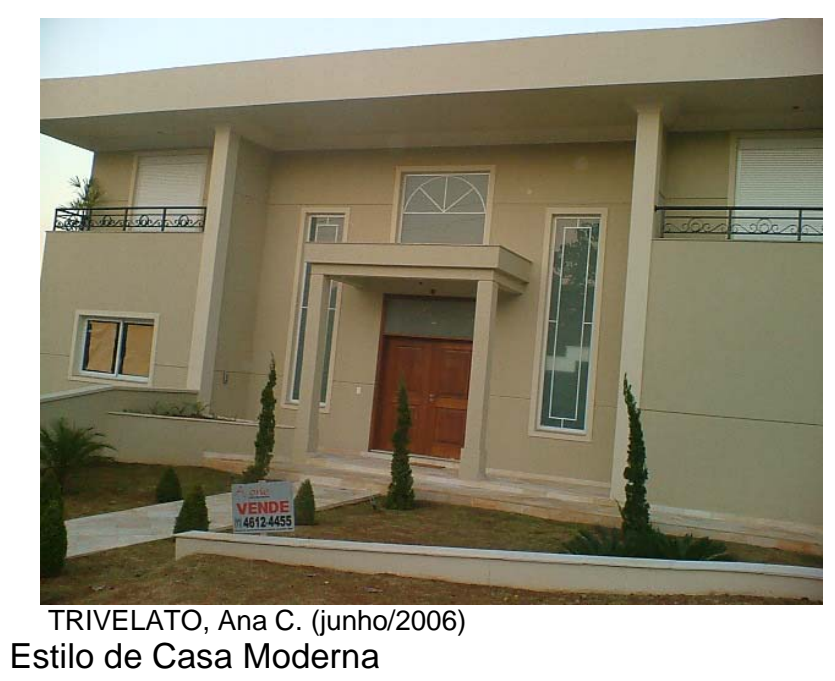

As três fotografias mostram estilos de casas de um mesmo loteamento (São Paulo II), e estão sendo apontadas por nós como edificações da personalidade dos próprios moradores

O lugar é construído como condição para a produção e para a vida, e ao serem construídas, essas condições produzem um espaço hierarquizado, diferenciado, dividido, contraditório, que se consubstancia como um dado modo de vida, como formas de relacionamento, como ritmos do cotidiano, como ideologia, religião e como um modo de luta. (CARLOS, 2003:52).

Nos bolsões residenciais, em que se busca separar em nome da segurança uma população de determinada classe social de outra, podemos perceber a manifestação da hierarquização dos espaços e, conseqüentemente de seus moradores, entre os mesmos de um único bolsão: as construções conseguem refletir o espaço onde mora "o vice-presidente da Mitsubish do Brasil" do lugar onde mora uma "pesquisadora em botânica": mesmo as grandes casas e os grandes lotes parecem manter o distanciamento que realmente existem entre eles: os mesmos não são capazes de "reconhecer" os seus próprios vizinhos, até mesmo porque praticamente esse tipo de relação não existe.

As pessoas de um condomínio ou bolsão residencial ainda que "compartilham" de um mesmo espaço como as ruas, os centros de convivência, o lago, não se conhecem: o relacionamento é mediado pelo administrador do condomínio (em geral empresas especializadas nessa área) que realiza reuniões (quase nunca freqüentada pelos "condôminos") e toma as decisões de acordo com o predomínio das "vontades" 
dos poucos presentes nessas: as pessoas não querem o comprometimento do seu tempo com coisas pequenas (como a decisão da cor da fachada de determinada portaria) e muito menos o "relacionamento" com o morador do seu mesmo loteamento, "não existe tempo para isso".

A necessidade da "exclusividade espacial" (seja ela por segurança ou hegemonia social) é tão grande entre os moradores da região que mesmo nos loteamentos residenciais encontramos os "subloteamentos", ou seja, dentro dos loteamentos residenciais, onde o acesso já é bem restrito, encontramos em alguns casos algumas poucas ruas que restringiram seu acesso colocando uma "segunda" portaria. O nível de "descomprometimento" com os "outros" do mesmo loteamento permite este tipo de ação, a ponto de que as pessoas não se sintam incomodadas com o fato, pelo contrário, essa restrição da restrição acaba se tornando mais uma opção alternativa à segurança de sua moradia, pois os "subloteamentos" acabam ganhando determinadas características que as diferenciam do bolsão maior.

Além dessa característica, a da segurança, o subloteamento também pode servir a redução de custos de uma parcela da população granjeira. Muitos dos antigos granjeiros têm visto seus filhos casarem-se ou ir morar no exterior. Com isso, a casa acabou ficando muito grande e as despesas com empregados e manutenção também. Como solução muitos moradores têm vendido suas casas e procurado morar nos subloteamentos (onde as casas são menores ${ }^{19}$ e os custos do dia-a-dia acabam se reduzindo também). Exemplo disso é o subloteamento chamado Carmel que se localiza no Condomínio ${ }^{20}$ Granja Viana II. Outra saída tem sido a compra de lotes próximo às portarias dos loteamentos (por causa do movimento rotineiro de carros o valor dos lotes é menor do que os que estão nas ruas cujo movimento é mínimo: novamente as distâncias interferindo nos valores, desta vez quanto mais longe da saída, maior é o valor do lote).

A frase "Tempo é Dinheiro", muito celebrada no mundo capitalista, nos ajuda a entender um outro aspecto que notamos na região granjeira: a constituição de

\footnotetext{
${ }^{19}$ Não estamos nos referindo ao tamanho dos lotes, mas ao tamanho das casas, que acabam não seguindo o rigor de cindo suítes, por exemplo.
} 
pequenos centros ${ }^{21}$ de consumo, muito próximos aos "conglomerados" bolsões e condomínios residenciais granjeiros.

Embora a maioria dos granjeiros mantenha sua vida profissional e social voltadas para a capital metropolitana como já dissemos, a sociedade granjeira, com o aval da municipalidade e interferência do setor privado, proveu o espaço granjeiro de um centro de consumo que não se compara ao centro de consumo da própria cidade de Cotia, de tão requintados que são os comércios e prestadores de serviços localizados entre os $\mathrm{Km} 23$ e 24 da rodovia Raposo Tavares.

Além desse centro de consumo, outros menores surgiram na área de extensão da Granja: tratam-se de pequenos centros de consumo imediato ${ }^{22}$ dirigidos ao consumo granjeiro. Esses últimos atendem os conglomerados ou os conjuntos formados pelos Condomínios e Bolsões residenciais na área expandida da Grana Viana, mas suas lojas e os prestadores de serviços não são tão requintados quanto àqueles localizados no centro de consumo do granjeiro tradicional dos Km 23 e 24 da rodovia Raposo Tavares.

Conseguimos localizar cinco diferentes centros de consumo que abastecem conglomerados de bolsões e condomínios residenciais granjeiros, excluindo aquele dos Km 23 e 24 da rodovia Raposo Tavares, pois este já é reconhecidamente o centro da região granjeira. Um deles está na Avenida José Giorge, outros dois ainda estão em formação na Estrada Fernando Nobre e na Estrada do Lutero, um quarto formado na Estrada do Embú e um quinto na Rua Jorge Caixe - Portão.

Vamos inicialmente tratar destes comércios de forma generalizada, afinal, partimos da premissa de que é a existência destes bolsões e condomínios residenciais que influenciaram na formação (e localização) destes centros de consumo imediato.

\footnotetext{
$20 \mathrm{Na}$ realidade trata-se de um bolsão residencial, cujos moradores, na sua grande maioria, compram equivocadamente seus lotes, pensando que estão comprando num condomínio só percebem depois de algum tempo que o loteamento é apenas um bolsão residencial.

${ }^{21}$ Sabendo-se dos vários autores que definem centros e centralidades, consideramos importante ressaltar aqui que os centros que vamos utilizar aqui, não é sob hipótese alguma o centro lefebvreano, como um campo de encontros e de trocas - no seu amplo aspecto, do vivido ou ainda do urbano. Estamos dizendo aqui do centro como àquele utilizado para "vendas de mercadorias" e "consumo", os encontros e trocas neste é artificializado e fugaz.

${ }^{22}$ Vale a pena dizer que os centros de consumo a que estamos nos referindo serve apenas para suprir as necessidades de consumo cotidiano dos granjeiros, melhor explicando, quando os granjeiros precisam de algum material de papelaria para seus filhos, "arrumar" os cabelos, ou locar um filme, esses pequenos centros lhes servem muito bem. No entanto, quando há a necessidade de algo mais requintado, diverso
} 
A respeito desses comércios que vão formando um pequeno centro de consumo, há algumas características que valem a pena serem mencionadas aqui: a primeira é que geralmente são os próprios granjeiros os proprietários dos estabelecimentos (muitas vezes gerenciados por eles próprios), existindo, inclusive, uma aparente preocupação dos consumidores em saber sobre quem é o dono do estabelecimento, de qual condomínio ele pertence e coisas deste tipo; é como se a procedência do comerciante pudesse interferir no tipo de atendimento oferecido aos consumidores.

Conversando com alguns empregados destes pequenos centros (às vezes se estende por uma rua inteira como na Avenida José Giorgi), tivemos como resposta que existe a procura dos granjeiros por um "bom preço", e ouvimos uma frase que conseguiu resumir muito bem o que todos disseram: “... não é porque é Granja Viana que eles compram coisas sofisticadas, querem sempre o mais barato. Acho que de sofisticado mesmo só compram as roupas e os carros..." (de uma vendedora - Loja Porto Seguro).

Os granjeiros parecem exigir os 3 "B": o bom, o bonito e o barato. Esses três adjetivos têm necessariamente que estar agregados. Segundo fala de alguns comerciantes, há uma exigência muito grande quanto a fachada dos comércios e exposição das mercadorias (a disposição dessas têm que estar a contento dos seus consumidores, que são considerados, pelos lojistas, como muito "críticos").

De acordo com uma lojista, no começo do ano ela supriu sua papelaria com o que havia de mais bonito e diferente quanto aos blocos, cadernos, canetas e coisas do gênero, e somente o mais simples (e conseqüentemente o mais barato) foi o que saiu até hoje. Segundo a mesma, é muito difícil investir comprando coisas diferentes (como os próprios consumidores pedem), pois fica tudo "encalhado". Segundo a ela o lugar "... é sofisticado, mas não tem rendimento. Para o vendedor é bom, porque os clientes são educados, mas para o dono é ruim porque quase não tem lucro".

ou novidade, então as lojas das Ruas Oscar Freire, Bela Cintra, Consolação, entre outras são as mais procuradas. 


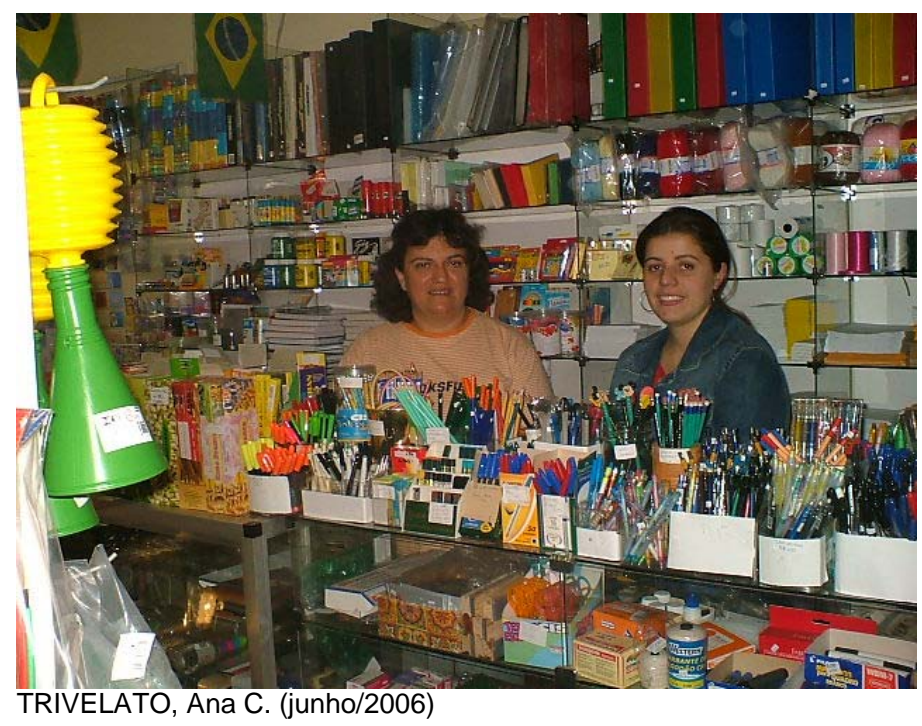

Foto da proprietária e vendedora de uma papelaria, a diversidade e o preço são fatores preponderantes para vender na Granja Viana.

A observação da proprietária nos reforça a idéia de que esses centros de consumo são realmente para atender as necessidades imediatas, para "aquele" consumo rotineiro, um imprevisto, uma mercadoria que fora esquecida num momento de compra maior em algum outro lugar, ou um consumo que represente um "ganho" de tempo e, portanto fica "mais em conta" consumir nestes centros do que se dirigir à um centro maior de compras, como na metrópole paulistana.

Ainda com relação aos locais de consumo, foi constatado que os granjeiros quando precisam de determinadas mercadorias que não encontram nesses centros de consumo imediato - algo de uma casa de ferragens, por exemplo - ainda que o centro de Cotia fosse o local mais indicado e próximo para um granjeiro ter satisfeita sua necessidade, este deixa claro, nas entrevistas realizadas, que para ele é preferível ir até São Paulo do que ir até o centro de Cotia. Entre os motivos alegados aparecem: a falta de estacionamento no centro de Cotia, as lojas talvez não tenham o que necessita (as fachadas do comércio no centro de Cotia são voltadas para o popular: grandes gôndolas com liquidações...), além de uma aparente confusão ${ }^{23}$ de pessoas nas calçadas o que torna inviável o caminhadas (ainda que só utilizem o carro).

Os espaços do centro cotiano são apropriados pela população de mais baixa renda e isso, aparentemente, é motivo para que outros dele não queiram se apropriar.

\footnotetext{
${ }^{23}$ No centro de Cotia, por haver um despreparo urbanístico quanto ao arruamento, calçamento e coisas do gênero, as pessoas andam na rua disputando o lugar com os carros.
} 
É como se houvesse um consenso e aceitação da lógica de que os espaços são, necessariamente, dirigidos para determinada finalidade e público alvo. Nesse sentido tal tipo de organização da cidade, por meio do parcelamento e uso do solo, acabam determinando o uso do espaço e a população à que este espaço está sendo dirigido de forma que ele seja segregador ou auto-segregador.. A respeito do poder do urbanismo e o domínio do espaço enquanto estratégia capitalista LEFEBVRE (1999:143), diz:

Essa estratégia oprime o "usuário", o "participante", o simples "habitante". Ele é reduzido não apenas à função do habitar (ao habitat como função), mas à função de comprador de espaço, realizando a mais-valia. O espaço torna-se o lugar de funções das quais a mais importante e velada é esta: formar, realizar, distribuir, de uma nova maneira, o sobreproduto da sociedade inteira (isto é, no modo de produção capitalista, a mais-valia global).

Espaços e funções, essas palavras parecem ser a chave para entender a produção espacial granjeira e a relação que ela mantêm com si mesma e com o seu entorno. Os espaços da Granja Viana nobre, seja para moradia ou consumo, são marcados por formas e comportamentos acessíveis somente aos granjeiros, sejam eles tradicionais ou os novos (granjolas). O entorno é ignorado, a auto-segregação se dá nos dois movimentos de quem está fora da região granjeira, e de quem está dentro também.

Os espaços granjeiros foram sendo produzidos à medida que a demanda surgia auto sugestionada por necessidades criadas pelo mercado para garantir a reprodução do capital seja na aquisição de lotes, na construção de casas ou na criação de centros de consumo, o movimento preponderante é dado pela força mercadológica, tudo pode ser vendido e comprado, o bem-estar, o status, a moda, o espaço e o próprio tempo.

A região denominada Granja Viana foi se expandindo e caracterizando muito bem os seus espaços, fosse pelas casas grandes e bonitas ou pelos centros de consumo imediato igualmente bonitos e diversificados, reforçando desta forma a idéia de que "... O espaço, considerado como produto, resulta das relações de produção a cargo de um grupo atuante..." (LEFEBVRE, 199:142). Assim, de forma bem generalizada, a Granja Viana nobre tem seu espaço voltado para seu público de classe média e alta, concentrando-se toda a infra-estrutura e aparato comercial de primeira grandeza neste espaço, pois são apenas os granjeiros que a priori vão consumir tudo o que está ali. 
Formas de viver e consumir metropolitanas são encontrados no dia-a-dia granjeiro, mas esse modo de viver da Granja não se transpõe à sua região do entorno e nem se manifesta no município de Cotia: o desnível econômico entre essa área (a granjeira) e as demais regiões cotianas é muito grande, salvo apenas por um único espaço, talvez por sua estratégica posição geográfica muito próxima a área do centro tradicional de Cotia, que ainda que formalmente estabelecido fora dos limites granjeiros atende o consumo dos moradores da Granja.

\section{Capítulo II. I. O Portão}

O bairro do Portão tem sua raiz constitutiva confundida com a própria história do centro da cidade de Cotia, pois, enquanto aglomerado, o centro cotiano se restringia ao "largo" que compreendia desde àquela época (1920) à Igreja Matriz e alguns poucos comércios. Com o desenvolvimento da atividade agrícola no município, este "largo" foi expandido e incorporou então um outro bairro chamado Portão - indicado abaixo.

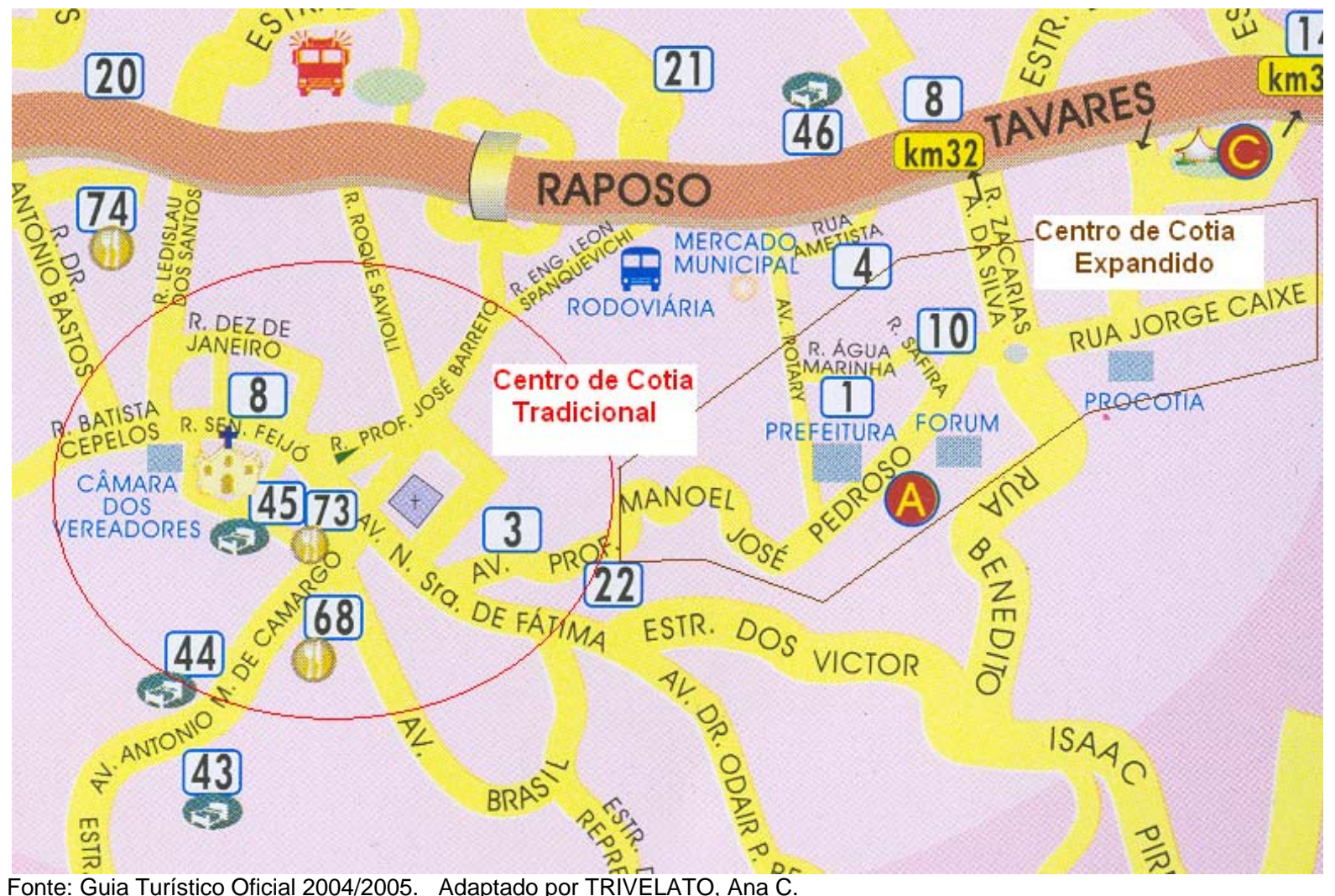


Este novo espaço urbanizado era cortado pela Rodovia Raposo Tavares, mas com o passar do tempo houve uma reconversão da rodovia (que hoje passa fora do centro de Cotia e do centro comercial do Portão também), e, embora a região urbanizada na época compreendesse o Km 30 ao 38 da rodovia Raposo Tavares, o centro propriamente dito se encontra no trecho do $\mathrm{Km} 30$ ao 33 da Rodovia Raposo Tavares, concentrando-se do lado esquerdo ${ }^{24}$ da mesma, onde não é possível ver da rodovia.

Logo no Km 30 da rodovia Raposo Tavares encontramos o bairro do Portão. Suas áreas foram por muito tempo (até o início da década de 1990) voltadas para moradias (classe média e baixa renda). Esta tendência foi mudando e, embora tenhamos ainda hoje muitas residências no lado direito da rodovia, o lado esquerdo foi sendo praticamente todo redirecionado para uma outra finalidade.

E a realização desse espaço enquanto condição gera um produto, que será condição de um novo processo, um novo momento, sua reprodução. Nesse sentido, a terra-matéria não pode ser reproduzida, mas o espaço o é constantemente, mudando de significado à medida que o processo histórico avança. (CARLOS, 2003:53)

O bairro do Portão tem, no seu lado esquerdo da rodovia, um condomínio de alto padrão e quase todas as instituições públicas (o prédio da prefeitura e os principais departamentos municipais da cidade, o Fórum e o Cartório de Registro Civil e de Imóveis). Se no passado era área de morarias hoje, no mesmo espaço temos uma mudança do uso dos edifícios aí existentes: quase todos tiveram o uso redirecionado pelo mercado imobiliário e transformados em comércio. Em cinco anos onde havia casas residenciais, hoje encontram-se lojas e prestadores de serviços que se diferenciam em muito dos comércios do centro de Cotia (este voltado para o consumo mais popular).

\footnotetext{
${ }^{24}$ Para localização geográfica textual, ao mencionarmos alguns pontos que julgamos importantes no trabalho, vamos nos utilizar sempre da rodovia Raposo Tavares como ponto de referência e o sentido "São Paulo - Interior" é o que vai nortear o que vamos posicionar como "à direita (da rodovia Raposo Tavares) e à esquerda (da rodovia Raposo Tavares).
} 


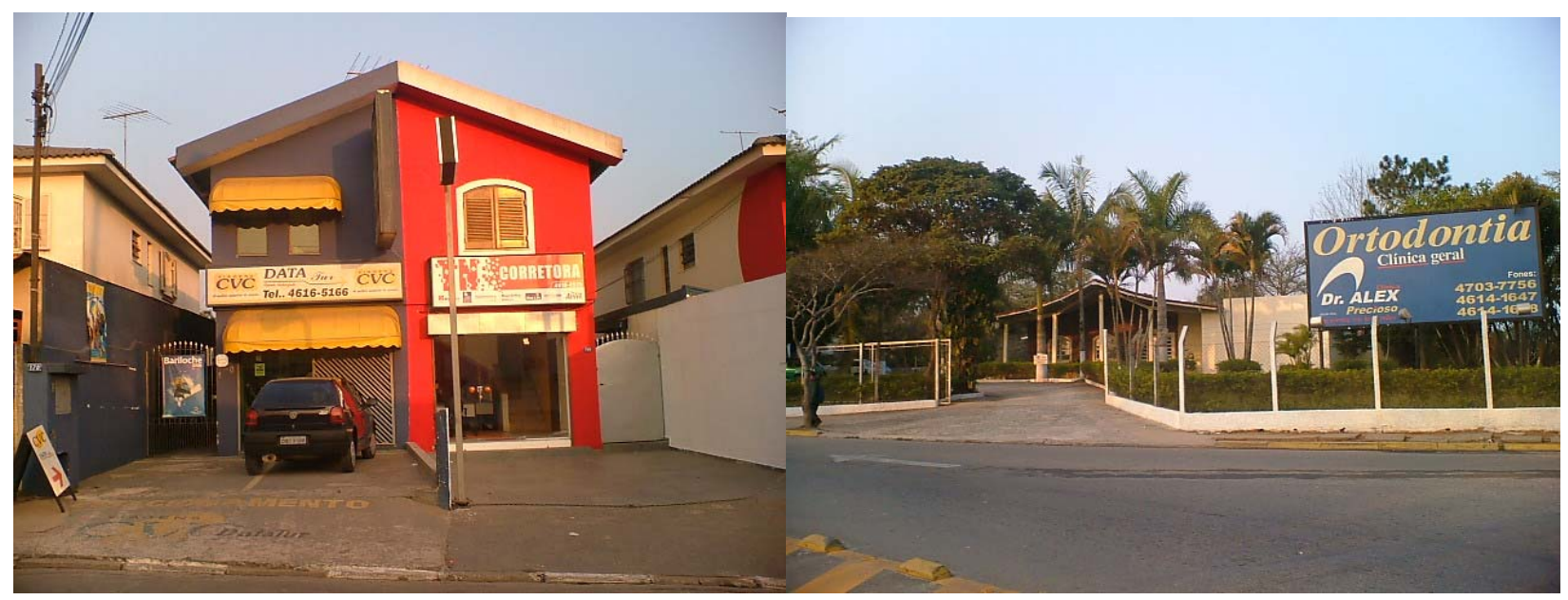

TRIVELATO, Ana C. (junho/2006)

TRIVELATO, Ana C. (junho/2006)

As fotos acima mostram as "antigas" residências do bairro do Portão com nova função, comércio e prestadores de serviços.

As fachadas dos comércios e prestadores de serviços desta porção do bairro do Portão ainda trazem como características resquícios da sua função anterior a este momento, ou seja, muitos centros de estética ou clínicas ortodônticas estão estabelecidos em edifícios que antes eram "casas residenciais". Assim, um bairro residencial de classe média e baixa renda foram num curto espaço de tempo transformado num centro de consumo. Não que as casas não existam mais neste bairro, ainda existe algumas, mas a maioria se transformou, as construções civis não estão voltadas para a função de moradia mais, mas para a função comercial.

O bairro do Portão é reconhecidamente extensão do centro de Cotia. O Portão faz parte da região central da cidade cotiana: uma das avenidas que constitui o bairro é inclusive a mesma que passa pelo centro de Cotia, a proximidade é muito grande do bairro do Portão e do centro cotiano. No entanto, o centro de consumo que foi se formando num determinado trecho do bairro do Portão se diferencia drasticamente àqueles do centro de Cotia, seja pelas fachadas, pelos tipos de serviços, valores ou disposições prediais ou urbanos (estacionamentos ou guias de estacionamento permitido).

Claramente o bairro do Portão não tem seu centro de consumo dirigido à mesma população que consome no centro de Cotia, e, depois de observar os mapas e 
pesquisar nas ruas, conseguimos perceber à quem de fato este centro de consumo do bairro do Portão está sendo dirigido, ou até mesmo, para quem ele foi criado.

Para podermos explicar, temos que voltar a considerar a região da Granja Viana, pois o bairro do Portão apresenta um vínculo maior do que poderíamos imaginar, pois parte desta região pulverizada da Granja Viana nobre (nova) está muito próxima à região central de Cotia, no bairro do Portão: é como se os condomínios que compusessem parte desta Granja Viana (nova) tivessem sido expandidos do Km 24 da rodovia Raposo Tavares para os "fundos" do bairro do Portão.

Desta forma, temos do lado esquerdo do bairro do Portão, dividido rodovia Raposo Tavares, "nos fundos" do bairro do Portão alguns bolsões residenciais que pertencem à Granja Viana nobre (nova). É interessante que poucas pessoas reconhecem àquela região como Granja Viana. Todos sabem que lá "mora gente rica", mas ninguém faz esta relação já que a região granjeira está muito ligada à localização espacial, ou seja, só é Granja Viana o espaço das proximidades do Km 24 da rodovia.

$O$ que conseguimos entender enquanto justificativa para as transformações espaciais de parte (lado esquerdo) do bairro do Portão foi justamente esta proximidade a extensão da Granja Viana, ou seja, vimos percebendo que já há uns 10 anos o bairro do Portão tem dirigido seu comércio para uma população diferente da central, melhor dizendo, mais precisamente há cinco anos atrás o comércio de parte do bairro do Portão está evidentemente se voltando para uma "elite" do que para a população que realmente constitui aquela região.

A região central do município de Cotia, é formada por uma população empobrecida e é onde encontramos o centro de consumo da população da região central do município, já os comércios do bairro do Portão (onde existe uma das favelas mais conhecida do município, a do "Morro do Macaco") estão claramente dirigida para uma outra população que não é a do Portão (o Portão dos "Morros", ou para melhor situar geograficamente: não é voltado para a população empobrecida do bairro do Portão, a que está do lado direito da rodovia Raposo Tavares).

No Portão temos um centro de consumo "requintado": há uma agência de turismo, clínicas de estética, lojas e papelarias cujas fachadas se distinguem dos demais comércios centrais, escolas particulares, floriculturas, docerias, cafés, clínicas 
(dentárias, oftalmológicas, médicas), enfim, uma oferta que não condiz com a demanda da população local da região central. Podemos afirmar que, embora o Portão seja parte da região central de consumo, parte do bairro está voltada para os granjeiros.
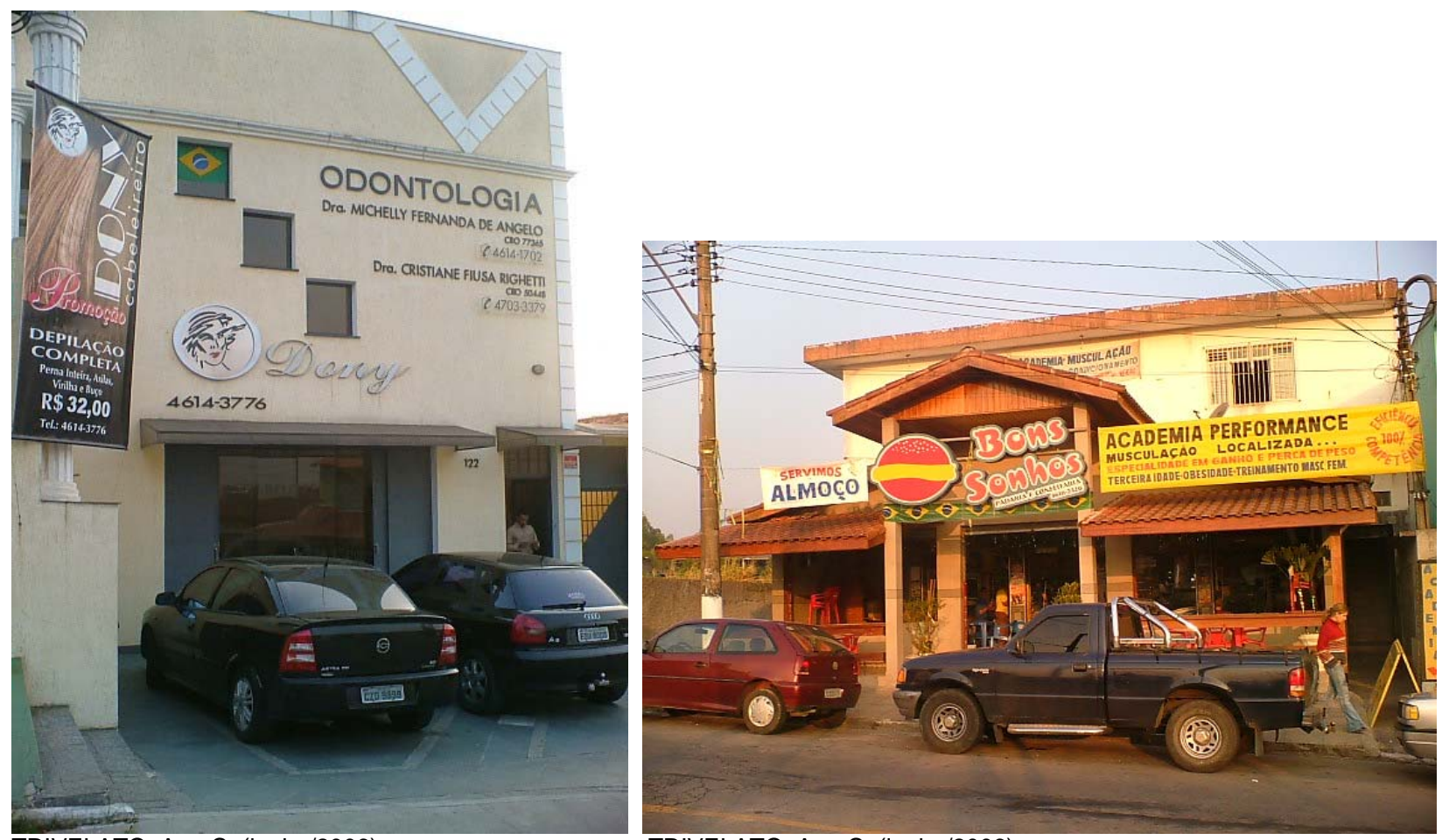

TRIVELATO, Ana C. (junho/2006)

TRIVELATO, Ana C. (junho/2006)

As fotos acima mostram o estilo diferenciado das fachadas do comércio e dos prestadores de serviços do bairro do Portão.

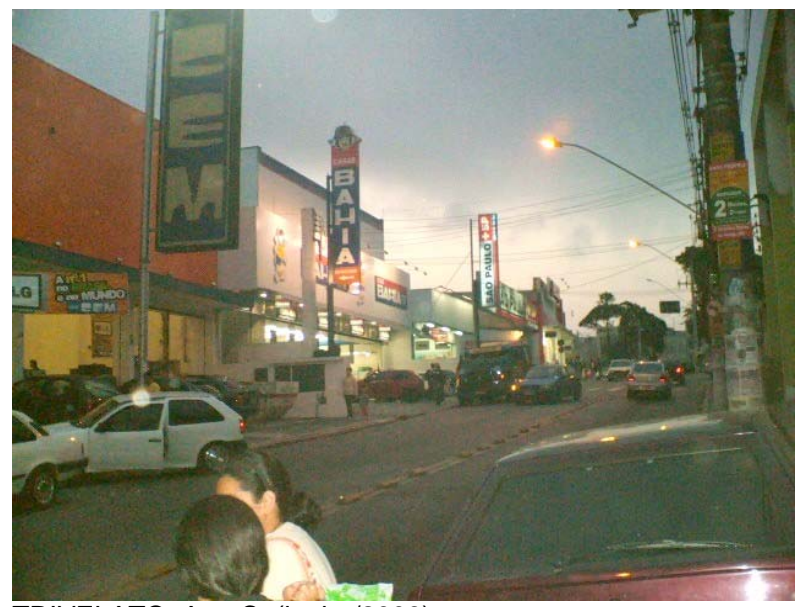

TRIVELATO, Ana C. (junho/2006)

É realmente muito contraditório ver todo aquele aparato comercial numa região que sabemos ser empobrecida. Reafirmamos que foi só por meio das entrevistas, análise dos mapas e a observação da dinâmica local, bem como a relação desta com

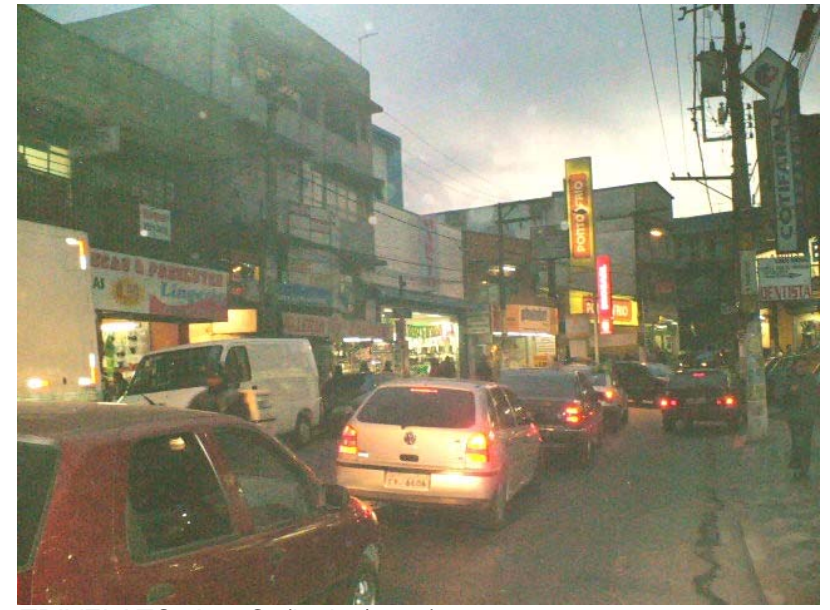

TRIVELATO, Ana C. (junho/2006) 
outras centralidades da Granja Viana nobre (nova) que foi possível fazer este tipo de relação, ou seja, para grande parte dos granjeiros que moram "nos fundos" do bairro do Portão se tornou muito mais cômodo usar (como necessidade imediata) todo o aparato oferecido neste local do que se dirigir até o centro granjeiro. Esta porção do bairro do Portão aponta como área de contato em que a extensão granjeira acaba particularizando um espaço que até então não Ihe pertencia.

Conseguimos inclusive, perceber as estratégias utilizadas para dificultar o acesso da população do centro de Cotia (popular); a primeira fica por conta das formas, as fachadas e os estilos dos comércios e prestadores são muito sofisticadas, inibindo o acesso da população que comumente consome no centro da cidade cotiana, a segunda é o próprio valor ${ }^{25}$ cobrado pelos produtos e serviços das lojas ali concentradas. Para oferecer seus produtos ou serviços, o bairro do Portão foi transformado para servir aos padrões granjeiros, mesmo que os comércios e prestadores de serviços deste centro de consumo imediato não assumam tamanha luxuosidade do próprio centro granjeiro instalado no $\mathrm{Km} \mathrm{24}$, a função é a mesma. Espacialmente o Portão nem se diferenciava das outras áreas comerciais do Centro de Cotia que atende ao consumo da população local (da região central da cidade).

Há um momento em que fica difícil de saber se é o "estilo granjeiro de consumir" que vai permeando os espaços enquanto tentáculos que segura para si tudo o que está em sua volta, ou se é o contrário, os espaços vão tomando forma para constituir o "modo de consumir" granjeiro. O fato é que fica muito claro os espaços destinados ao consumo desta população nobre de Cotia, as fachadas, os produtos, os serviços, a rua, o paisagismo, a limpeza, as pessoas, os carros, o acesso, tudo funciona como indicativo de que àquele espaço é destinado a uma população específica, e só a ela.

A mídia e o marketing se apropriam de tal forma de "estilo único de consumir granjeiro" até para vender imóveis para além dos espaços Granjeiros. Hoje, quando se quer vender uma área em Cotia, o mercado imobiliário, em uma estratégia de venda, vincula, nas propagandas imobiliárias, os novos loteamentos à região da Granja Viana

\footnotetext{
${ }^{25}$ Somente para ilustrar temos o exemplo de preços de cabeleireiros (pesquisa realizada em setembro de 2005), enquanto os salões do centro cobravam por um penteado cerca de $R \$ 70,00$ neste bairro o valor ficava entorno de $\mathrm{R} \$ 150,00$.
} 
ou, mais precisamente, ao centro de consumo criado no $\mathrm{Km} 24$ da rodovia Raposo Tavares, de modo que um imóvel tenha mais valorização ou aceite enquanto produto a ser consumido.

O bairro do Portão é a área intermediária entre a Granja Viana, (sempre associada à luxuosidade, requinte e riqueza) e a região central do município, conhecida pelos morros, casas auto-construídas, áreas ocupadas irregularmente, bairros muito pobres e pessoas muito humildes: são dois espaços que embora muito diferentes são vendáveis para públicos diferentes, mas com uma semelhança muito grande num único aspecto.... a escassez do solo.

Em Cotia, de acordo com a legislação vigente, as construções só podem ser feitas horizontalmente: a última tentativa para conseguir um alvará para construção de um prédio na Granja Viana, ainda na década 1.990, pleiteada pelo Sr. Márcio Miksube, resultou numa organização granjeira que forçou a aprovação da lei que proíbe a construção predial com mais de 12 metros de altura no município de Cotia, ou seja, nada acima de quatro pavimentos pode ser construído na cidade cotiana, seja em qual região for.

O lado direito da Granja Viana, diga-se de passagem, o lado mais caro (valorização devida a criação do centro de consumo e serviços na proximidade dos $\mathrm{Km}$ 23 e 24 da Raposo Tavares), sempre foi a "menina dos olhos" do mercado imobiliário local, mas hoje é um espaço um tanto esgotado e raro. Em função disso o mercado imobiliário está "forjando" uma extensão da região da Granja Viana, invadindo a região do Centro de Cotia.

A Granja Viana é a região nobre de Cotia, e é justamente este atributo que lhe dá a condição de uma "centralidade econômica". Como morar na Granja Viana é garantir um certo "status", o mercado imobiliário hoje vende a idéia de proximidade para valorização de novos loteamentos. O novo marketing é: "More próximo à Granja Viana".

Morar próximo a Granja Viana, permite a difusão do seguinte discurso: "Você pode usufruir toda a infra-estrutura granjeira, inclusive do centro comercial e prestadores de serviços" e ainda dá para completá-lo garantindo que "Com mensais a partir de $\mathrm{R} \$ 414,44$ você pode ser um granjeiro também". Queremos mostrar que a 
necessidade de (re) produção do capital fez com que o mercado imobiliário da Granja Viana fosse capaz de valorizar até suas proximidades.

Isso podemos observar no anúncio publicado no jornal Oferta de Imóveis de 03/06/06. O anúncio mostra a fachada do loteamento e o centro de consumo granjeiro (paralelo a rodovia Raposo Tavares) e para reforçar a idéia de que os moradores deste loteamento (Residencial Villa D'Este) vão poder mesmo usufruir de todo o centro comercial granjeiro "nobre", o anúncio informa que : "Junto à Granja Viana com: préescolas, colégios, universidades, supermercados, shopping, restaurantes cinemas, academia e hospitais." O anúncio tenta vender o espaço e toda a infra-estrutura e aparato comercial da Granja Viana (nobre) como se todos igualmente pudessem desfrutar de tudo o que o espaço oferece. A idéia de que o residencial está próximo à Granja Viana e junto a esta centralidade (avistada da rodovia Raposo Tavares e exposta no anúncio) há escolas, restaurantes, cinemas e coisas do gênero. Passa uma falsa idéia de que o comprador do loteamento poderá consumir do que há de mais requintado na região.

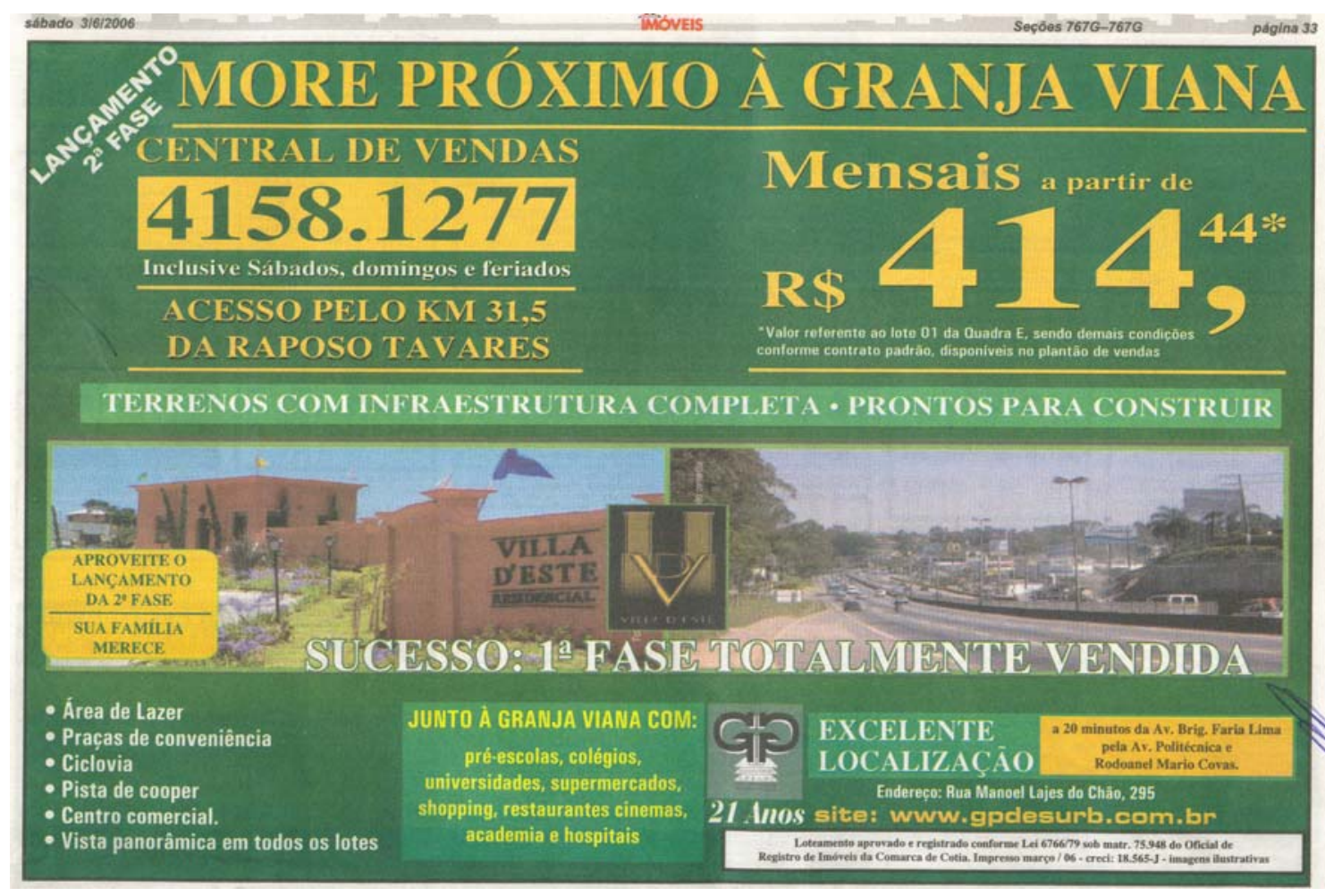

Fonte: Jornal Imóveis, 03/06/2006:33 
O acesso à Granja Viana nobre é restrito: o signo que permeiam todo aquele lugar é auto-segregador. As pessoas que pudessem comprar um lote neste residencial, onde se podem pagar mensais a partir de $\mathrm{R} \$ 414,44$ - queremos chamar a atenção para o valor, pois este indica o seu "público alvo", que não pode ser comparado com os Condomínios ou bolsões residenciais cujo valor do condomínio ultrapassa por vezes o valor desta mesma mensalidade - muito provavelmente não conseguiriam acessar tudo o que o anúncio promove como sendo de uso público.

Ao acessarmos o site da empresa responsável em lotear o Residencial Villa D'Este, encontramos como auto apresentação da empresa o seguinte

A GP Desenvolvimento Urbano desenvolve produtos totalmente aprovados e anuidos pelos órgãos Estatais, o que garante que o seu lote está inserido num empreendimento ecologicamente equilibrado, e socialmente desenvolvido. A GP tem sido colocada entre as principais empresas do setor de loteamentos e desenvolvimento urbano do Estado de São Paulo, e do Brasil. (www.gpdesurb.com.br 15/06/06).

Já na primeira frase encontramos um engodo no entendimento de "ecologicamente equilibrado": pela própria ilustração da fachada do residencial no anúncio e as fotos apresentadas no site do local do loteamento, não percebemos a mata que poderia garantir este "equilíbrio"; a existência de um pequeno jardim na portaria do residencial e um gramado no seu interior (de acordo com as fotos abaixo) parece ser o suficiente para "garantir" o equilíbrio descrito como preocupação sine qua nom da empresa.

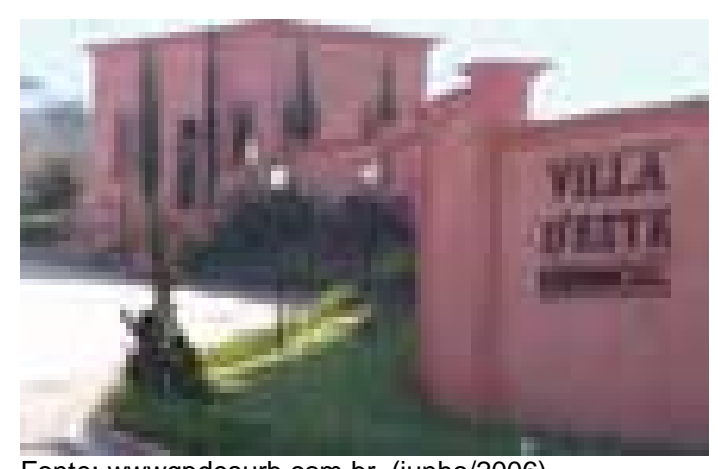

Fonte: wwwgpdesurb.com.br (junho/2006)

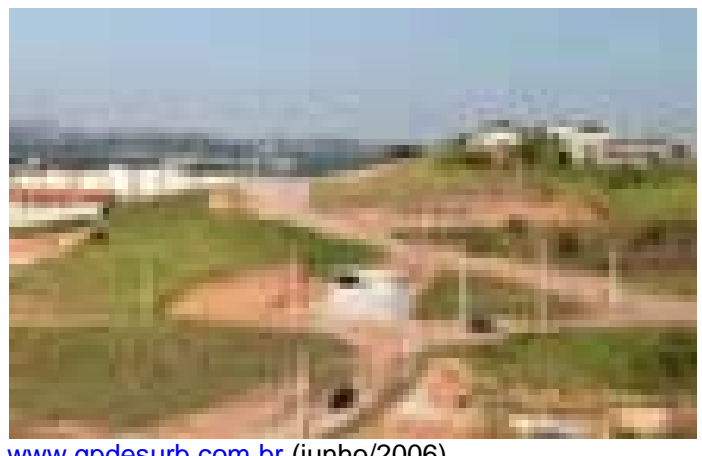

www.gpdesurb.com.br (junho/2006)

O segundo aspecto é a classificação da empresa dentre as demais empresas do ramo. A apresentação inspira uma confiança e provém de crédito uma empresa que está se utilizando imagens do anúncio como forma de ludibriar seus compradores em 
potencial, pois no anúncio está que o acesso se dá pelo $\mathrm{Km} \mathrm{31,5}$ da rodovia Raposo Tavares. Convém lembrar que a Granja Viana nobre é vista no Km 24,0 da mesma rodovia o que implica em dizer que existe uma certa distância a ser considerada (pelo menos $6 \mathrm{Km}$ ). Claro que a distância percorrida de carro é pequena, mesmo assim a representação disso em um mapa sem escala implica na necessidade estratégica do mercado da venda da imagem e proximidade da Granja para valorização dos novos empreendimentos. Ao visitarmos o mapa de localização do empreendimento no site, verificamos o seguinte:

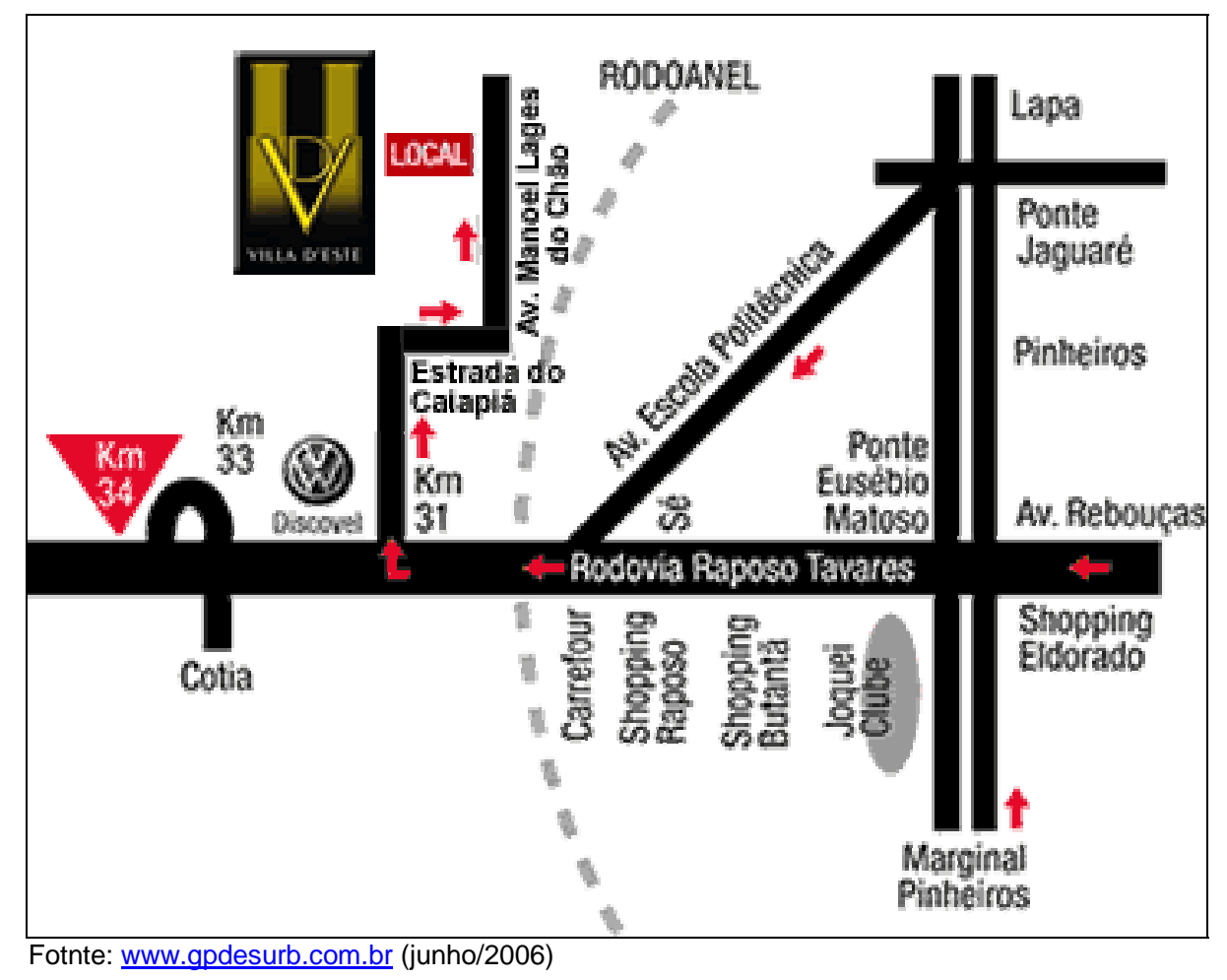

Pelo croqui de localização do empreendimento (este não foi publicado no anúncio do jornal, mas é possível encontrá-lo no site), o Residencial Villa D’Este está geograficamente muito mais situado no bairro do Portão (lado direito), pertencente à região central de Cotia, do que na Granja Viana. O anúncio do jornal diz que o acesso é feito pelo $\mathrm{Km} \mathrm{31,5}$ da rodovia Raposo Tavares, dando a impressão de que pelos "meandros asfálticos" o motorista pudesse se aproximar do $\mathrm{Km} 22$ ao Km 25, ou seja, as fotos e as palavras podem confundir o interessado no anúncio, pois o anúncio "More próximo à Granja Viana" e as fotos mostrando a portaria do Residencial Villa D'Este de um lado, e do outro o centro de consumo imediato granjeiro do $\mathrm{Km} 24$ da rodovia 
Raposo Tavares, faz com que o interessado pense que embora o acesso se dê pelo $\mathrm{Km}$ 31,5 da rodovia Raposo Tavares, ele ainda esteja próximo à Granja, mas observando o mapa vemos algo diferente deste raciocínio.

Talvez seja proposital o erro enorme de proporção existente neste croqui quando analisamos a distância do residencial do Rodoanel, cuja saída está localizada aproximadamente no Km 19 da rodovia Raposo Tavares, mas nos sentimos inclinados em considerar a "má fé" da empresa que promove este tipo de anúncio, já que a distância deste bairro para a Granja Viana não permitiria colocar as duas fotos (da entrada do residencial e do centro de consumo granjeiro) insinuando tal proximidade a ponto de que o comprador e futuramente o morador pudesse usufruir da Granja Viana nobre, já que os retornos estão muito distantes (Km 32 da Rodovia Raposo Tavares e um outro no Km 23 da mesma rodovia).

O potencial de consumo (considerando o interesse do comprador pela mensalidade do imóvel) e a distância dos retornos para quem estivesse morando no Residencial Villa D'Este seriam aspectos relevantes no acesso deste no centro granjeiro nobre de consumo. A venda de uma proximidade "virtual", já que ela só é possível na foto do anúncio, da região central de Cotia à Granja Viana nos mostra o poder de "influência ou status"

De acordo com LEFEBVRE (1999:143) a estratégia capitalista de reprodução do capital por meio da especulação imobiliária:

...vai muito mais longe que a simples venda, pedaço por pedaço, do espaço. Ela não só faz o espaço entrar na produção da maisvalia, ela visa uma reorganização completa da produção subordinada aos centros de informação e de decisão.

Somos levados a pensar que há uma ideologia que não é apenas local, mas um consenso que garante a "super valorização" dos espaços granjeiros ou ainda a garantia de venda de lugares próximos à esta região, a Granja Viana não é somente vendida, ela é transformada em produto, existe uma "embalagem" e muita propaganda para vender seus espaços.

É difícil saber o que realmente é a Granja Viana, que espaço é este que toma tudo a sua volta para si mesma. Ela é inteira porque existe uma identidade forte entre a 
região e seus moradores individualmente, mas é ao mesmo tempo despedaçada, pois os vários condomínios e bolsões residenciais vão particularizando os muitos "centros" de consumo do mesmo, as muitas áreas de convivência entre os mesmos, a distribuição limitada de "senhas" de convivência. É a abundância e a escassez, o muito e o pouco, o grande e o pequeno, o tudo e o nada...ao mesmo tempo. 


\section{Capítulo III. Tudo é Granja!}

Desde os primórdios da industrialização, o desenvolvimento da técnica foi perseguido com o único objetivo em aumentar o ritmo produtivo buscando garantir a reprodução e acúmulo do capital por meio da produção em massa. A atividade industrial tornou-se o alicerce para a reprodução do sistema capitalista que, na promoção da produção e consumo, investiu cada vez mais na inovação produtiva e definiu padrões de consumo, instigando o desejo de consumir, perpetuando a necessidade de uma jornada cada vez mais longa de trabalho, segundo uma divisão social que acabou rompendo os portões das indústrias, inserindo-se na vida cotidiana para produzir o espaço enquanto mercadoria.

O processo de desenvolvimento industrial foi o grande "promotor" do 'desenvolvimento' do espaço favorecendo a evidente oposição do valor de uso enquanto a possibilidade do encontro, pelo uso dos edifícios e dos espaços públicos da cidade, substituídos, enquanto uma tendência, pelo valor de troca com grande ênfase na mercantilização e consumo dos espaços, dos produtos e dos signos da cidade.

Não havendo a possibilidade de pensar as relações sociais construídas na cidade sem a realidade presente dada pelo espaço, bem como a construção do espaço enquanto intervenção social, pois as relações sociais se produzem efetivamente enquanto relações espaciais entendem que a cidade, espaço produto e constituinte de relações sociais, estes vão se recompondo por meio do conjunto de mútuas mediações. Segundo (CARLOS, 2004:20)

A sociedade constrói um mundo real e objetivo; na prática socioespacial, esse mundo se revela em suas contradições, num movimento que aponta um processo em curso, que se realiza enquanto relações espaço-temporal...as relações sociais têm uma existência real enquanto existência espacial concreta na medida em que produzem, efetivamente, um espaço, aí se inscrevendo e se realizando, as relações sociais produzem um lugar determinado através de um tempo que marcaria a duração da ação. É assim que, espaço e tempo aparecem através da ação humana em sua indissociabilidade.

A morfologia, enquanto entendimento das formas, distingue-se na sua vertente dada pelo cunho material e pelo social. Enquanto o primeiro diz respeito à quantidade, 
forma, distribuição e até distância de uma estrutura da outra num dado espaço, o segundo caracteriza-se por um conjunto de condições sociais, nas quais incluímos as relações econômicas e culturais dadas num dado período de tempo.

O tempo produtivo caminha num ritmo descompassado de trajeto nem sempre contínuo. O tempo notado pelas mudanças espaciais que socialmente são construídas, reproduzidas e transformadas num período vasto dos extremos produtivos - numa ponta o artesanal e na outra o industrial - se materializaram e marcaram uma sociedade, seus costumes, suas ideologias, enfim, sua história.

A relação espaço e tempo estreita-se ainda mais quando procuramos entender as representações impingidas ao espaço urbanizado como criação social, dado as continuidades e descontinuidades do tempo onde "...no curso do desenvolvimento, formas transformam-se em funções e entram em estruturas que as reformam e as transformam..." (LEFEBVRE, 2001:54). Ou ainda de acordo com o mesmo autor, LEFEBVRE (1983:50 e 51):

Consideremos la relación entre el espacio y el tiempo. Los dos infinitos simultáneos y actuales se disciernen y se cruzan en la representación (...) el espacio no se representa y no se mide sino por y el tiempo finito... ${ }^{26}$.

Não é possível, portanto, pensar espaço ou tempo de forma dissociada. O espaço necessita do tempo para se constituir, da mesma forma que o tempo precisa do espaço para se materializar pelo trabalho do Homem.

Embora o espaço seja passível de ser mensurado pelo tempo finito, temos nas continuidades e descontinuidades deste mesmo tempo o desenvolvimento das formas que estão no espaço - em funções que retornam ao curso do desenvolvimento e novamente são transformadas e daí temos as possibilidades e as superações, não havendo, portanto, um movimento cíclico e nem unilinear portanto, pois segundo CARLOS (2004:22)

... O espaço, produzido enquanto mercadoria entra no circuito da troca atraindo capitais que migram de um setor da economia para outro, de modo a viabilizar a reprodução, o que explica a

\footnotetext{
${ }^{26}$ Tradução da autora: "Consideremos a relação entre o espaço e o tempo. Os dois infinitos simultâneos e atuais se discernem e se cruzam na representação (...) o espaço não se representa e não se mede senão por um tempo finito..."
} 
emergência de uma nova lógica associada a uma nova forma de dominação do espaço que se reproduz, ordenando e direcionando a ocupação, fragmentando e tornando os espaços trocáveis a partir de operações que se realizam no mercado. Desse modo, o espaço é produzido e reproduzido enquanto mercadoria reprodutível...

Tomemos aqui as transformações da região granjeira para conseguirmos nos fazer entender quanto a relação que estamos querendo evidenciar, o espaço e tempo na constituição do urbano, melhor dizendo, da vida urbana.

Em 1917, Cotia continuava servindo como "caminho" e era conhecida por ser a rota dos "caminhos de burros" que ligavam São Paulo a Sorocaba e sua primeira função urbana foi a de formar um "aglomerado de pouso" para os viajantes. Já município em 1956, Cotia tinha na agricultura e pecuária suas atividades de subsistência e o excedente era comercializado na capital paulistana.

Neste período da história, uma fração do espaço no município portava-se como um pequeno núcleo urbano com alguns poucos e precários comércios que atendiam os tropeiros que passavam por ali e um pequeno aglomerado de uma população que começava a fixar-se no município, em terras circunvizinhas, para exercer principalmente a agricultura, embora a pecuária também existisse.

As trilhas de outrora, que ligavam a capital ao sudoeste do interior paulista viraram estrada estadual em junho de 1921 durante o mandato de Washington Luís, a SP-270 (denominada rodovia Raposo Tavares desde 1954) era São Paulo - Paraná e em janeiro de 1974 é declarada de utilidade pública a faixa de domínio de 50 metros para a estrada que faz a ligação da capital à região oeste de São Paulo, atendendo os municípios de Cotia, Sorocaba, Alto do Paranapanema, norte do Estado do Paraná e Mato Grosso do Sul. Com a chegada da colônia japonesa no período que compreende as décadas de 1920 a 1940, com um vasto conhecimento em cultivo, a cultura hortigranjeira foi sendo cada vez mais estimulada. Ou seja, Cotia, no caso, deixa de ser local de passagem e pousada de tropeiros e vai se transformando em área produtora de hortigranjeiros. Os negócios que antes eram feitos pelos próprios agricultores no 
"Largo da Batata - Pinheiros"27 com os excedentes da sua produção (a maioria predominantemente cultivava batatas), passou a ser incorporado cada vez mais pelos produtores locais destacando a atividade como principal atividade econômica da cidade. Segundo o Sr. Kira ${ }^{28}$

...Tudo o que era plantado nessas terras, legumes, verduras e batatas, era vendido no Mercado de Pinheiros, muitas vezes pelas mãos de atravessadores que se aproveitavam da dificuldade de comunicação dos japoneses. Essa foi uma das razões para a fundação da Cooperativa Agrícola de Cotia (CAC)....

A fundação desta CAC foi de muita valia para a cidade na época por permitir a ascensão em importância Estadual (São Paulo). Vale destacar que a sede da Cooperativa Agrícola de Cotia localizou-se no bairro Moinho Velho, que fazia parte da região da Granja Viana, que surge então como empreendimento de projeção e importância econômica e de abastecimento da região metropolitana de São Paulo.

É curioso notar que, embora o município tivesse seus espaços transformados e urbanizados, a importância em manter o vínculo efetivo com as centralidades de São Paulo era absolutamente importante, considerando que a produção econômica do município (hortigranjeira) não era efetivada em Cotia por falta de um mercado consumidor local que fosse grande o suficiente para garantir o "lucro" para o tipo de oferta. Embora uma fração do espaço cotiano estivesse em transformação, ou ainda, em desenvolvimento urbano, a maior parte da população ainda "cultivava" mantendo, por meio do desenvolvimento da atividade hortifrutigranjeira, uma cidade onde a presença do modo de vida rural ainda era muito marcante.

O próximo momento do município é marcado pela industrialização, permitindo a valorização e transformação do espaço em mercadoria. Vamos acelerar um pouco mais no tempo até chegarmos na década de 1970 no período do "milagre econômico" no Brasil, quando se inicia um processo de desconcentração industrial paulista que ocorreu em direção a região metropolitana e ao interior paulista. Inicialmente a ação

${ }^{27}$ O Largo da Batata localiza-se em Pinheiros, um dos bairros mais antigos da cidade de São Paulo. O Largo recebeu este nome por tornar-se centro comercial dos agricultores das cidades que abasteciam São Paulo.

${ }^{28} \mathrm{O}$ Sr. Kenji Kira é filho de imigrantes japoneses e nasceu na Granja Viana em 1932, de vida política bem atuante na cidade de Cotia, foi vereador na década de 1960 e prefeito na década de 1970, hoje ainda morador da Granja Viana tem suas atividades voltadas ao empresariado. 
tentava, entre outros objetivos, enfraquecer as ações do sindicato da cidade paulistana, mas depois com a tendência a substituição do setor secundário (indústria) pelo setor terciário (comércio, comunicação, pesquisa e serviços), alguns tipos de indústrias (ou o setor de produção das mesmas), tendem a deslocar-se paulatinamente da cidade de São Paulo (que passa a aglutinar principalmente ao setor terciário e serviços de ponta) e vão para cidades da região metropolitana, como Cotia.

Com as melhorias viárias causadas pela duplicação da rodovia Raposo Tavares aliadas a nova política governamental a respeito do desenvolvimento industrial, Cotia viu no entorno da rodovia Raposo Tavares a instalação crescente de muitas indústrias de capital estrangeiro e nacional, criando um extenso bolsão industrial que compreende do $\mathrm{Km} 27$ ao $\mathrm{Km} 33$ da rodovia. A maior parte das indústrias aqui instaladas desde esta época era de produção química, deixando como herança para o município os passivos (metais pesados) hoje facilmente identificados na análise do solo e de águas subterrâneas. No entanto, com este fato queremos enfatizar aqui não exatamente o cunho ambiental enquanto impacto negativo da industrialização pela criação de passivos no solo cotiano, mas nos utilizarmos desta situação como um indicativo para percebermos a própria importância que o solo apresentava neste momento. A terra enquanto cumpria com sua função social na época de uma Cotia produtora primária despertava uma atenção especial de seus proprietários quanto ao cuidado com o que se colocava na terra por meio de pesticidas ou adubos (até para garantir uma boa produção e conseqüentemente bons rendimentos) $)^{29}$. Com a industrialização, a perspectiva da terra enquanto mercadoria é tão latente que a preocupação de seus proprietários passa a ser quanto aos "valores agregados" por meio da infra-estrutura e localização desta no mercado especulativo imobiliário e não mais na sua "qualidade produtiva".

A terra, que era preservada e cuidada quando tinha como função principal a manutenção da vida da sociedade por meio da prática agrícola (fosse para subsistência

\footnotetext{
${ }^{29}$ Diferentemente das indústrias, muitas contaminaram o lençol freático com metais pesados, a exemplo temos a intervenção em Cotia pela Cetesb (órgão do Estado responsável em fiscalizar os procedimentos e inertes industriais), que em 2004 embargou o funcionamento da indústria Delphi, no Km 31 da rodovia Raposo Tavares, pois verificou-se uma contaminação das águas subterrâneas (verificado por
} 
ou comercialização), aos poucos perdendo esta função distanciando-se da sua condição de natural e assumindo a condição de produto. A produção do espaço urbano é criada de forma desigual, porque vai desenvolvendo-se de forma diferenciada, transformando frações espaciais em determinados momentos de acordo com determinadas funções.

LEFEBVRE (2002:41 e 42) distingue cidade e campo pelas oposições que se desenvolvem da seguinte forma:

...trabalho material e trabalho intelectual, produção e comércio, agricultura e indústria (...). Ao campo correspondem formas de propriedade fundiária (...). À cidade correspondem outras formas de propriedade: mobiliária (...), corporativa, mais tarde capitalista...

Esta distinção clássica entre campo e cidade nos ajuda a mostrar por meio da produção de novos espaços a passagem do município de Cotia de uma atividade econômica (basicamente agrícola) para outra (basicamente industrial). Esta passagem fica cristalizada no espaço, pois Cotia vai deixando a sua 'ruralidade' para tornar-se uma 'cidade'.

Esta transformação espacial pode ser melhor datada em Cotia a partir de 1953, por meio da aprovação de leis que incentivaram a industrialização por meio da isenção de impostos. Em 1971 a prefeitura estabelece, pensando estar dando uma alternativa econômica para o município (empregos para os contribuintes), a isenção, para as indústrias, do pagamento de impostos por até 20 anos, decisão que foi significativa na constituição do bolsão industrial do município.

Na visão do Sr. Kira, um dos prefeitos desta época:

...Cotia precisava de mais receita e, para isso, tinha que trazer indústrias para cá. Como trazer indústria se a cidade não tinha luz elétrica decente, não tinha estrada, não tinha telefone. Por isso, fiz um Plano Diretor, com toda a infra-estrutura necessária para trazer mais indústrias para a região, que a Câmara não aprovou.

Mesmo com a resistência da Câmara dos Vereadores de Cotia, o estímulo à industrialização foi dado. As indústrias instaladas aí tinham a garantia de circulação e escoamento rápido da mercadoria por meio da rodovia Raposo Tavares, isenção de

amostragens retirados de poços de águas locais) num raio aproximado de $3 \mathrm{Km}$ (duas indústrias alimentícias usavam dessa água: Sorvetes San Luiger e Brico Bread Pães). 
impostos, infra-estrutura e mão-de-obra barata garantidos. A idéia de que "mais indústria representa mais emprego e mais receita..." (Sr. Kira) persiste até os dias de hoje, garantindo as transformações de frações espaciais voltadas para a industrialização ainda na atualidade.

Algumas indústrias, já naquela época, eram automatizadas eliminando a possibilidade de emprego aos cotianos e outras demandavam mãos-de-obra especializadas, exigindo um conhecimento que os "caipiras" da região ainda não possuíam, justificando o emprego de mão-de-obra dos paulistanos e o interesse dos cotianos em ajustar-se à nova fase econômica do município.

Segundo CARLOS (1986:146)

Cotia sofre uma profunda alteração na sua estrutura econômica, à medida que o setor industrial se afirma, e se expande, impulsionando a transformação dos serviços de produção e consumo, bem como sua diferenciação. A importância do setor primário cai expressivamente, e Cotia passa a fazer parte da divisão espacial do trabalho, na metrópole paulista, não mais como área exclusivamente agrícola; conseqüentemente a população rural decresce.

Ainda hoje temos muitas empresas na extensão da Rodovia Raposo Tavares (e ruas vicinais à esta) como a Impsat, Payot, Lucas CAV do Brasil, Dematic Cranes Components, Firmenich, Danisco, Astra Zenica, enfim uma gama de empresas localizadas e facilmente identificadas durante um bom trecho da rodovia Raposo Tavares. E se a população cotiana até a década de 60 era predominantemente rural, verifica-se que a taxa de urbanização sobe de 24,39\% em 1950 à 95\% em 1970, e a taxa geométrica de crescimento anual cresce significativamente, de 2,6 nas décadas de 50/60 para 6,9 nas décadas de 60/70 e 7,4\% nas décadas de 70/8030.

Há com a transição do desenvolvimento econômico agropecuário para o industrial dois efeitos de ordem migratória populacional que se efetivaram no município, cada qual voltado para um público alvo diferente. O primeiro diz respeito aos migrantes nordestinos em busca da oferta de emprego dado o aglomerado industrial, desenvolvendo então a atividade imobiliária na criação de bairros populares, muitas vezes em loteamentos irregulares, localizados em áreas de topografia irregular e com o 
provimento de infra-estrutura tardia em geral só obtida por pressão dos moradores, e muitas vezes, mesmo quando provida, de modo ineficientes. O segundo foi estabelecido pelo fato de que as

...mesmas melhorias na rodovia valorizam as terras limítrofes, o que, aliado à ausência de ferrovia, dificultando o acesso rápido ao parque industrial da Metrópole, leva a um direcionamento maior da atividade imobiliária às classes média e altas visando moradias de alto padrão, chácaras de fins de semana (...). Ganha peso, nesse sentido, a partir, de 1950, o bairro da Granja Viana. (Lei Complementar 001/91 - II.1. Cotia e a Grande São Paulo).

A região que compreende a Granja Viana pertencia de forma expressiva ao Sr. Niso Viana ${ }^{31}$, que tinha, na região, por principal atividade na sua fazenda a pecuária bovina (o gado - de leite- foi ainda na década de 1940 importado da Holanda, Estados Unidos e Canadá). No entanto, com a passagem da rodovia Raposo Tavares e o estabelecimento de algumas indústrias, o Sr. Niso assimilou o parcelamento de suas terras para o desenvolvimento local, originando as primeiras chácaras e sítios dos paulistanos que buscavam no "interior" da capital momentos de proximidade com a "vida no campo". A partir das décadas de 60 e 70 a Granja Viana passou por um novo parcelamento e agraciada pela Lei de Parcelamento de Solo e Zoneamento do município. Assim os Condomínios e Bolsões Residenciais passaram a adensar a região com grandes e privilegiados lotes voltados para o mercado imobiliário, cujo público alvo são paulistanos de classe média e alta e de outras localidades, e novamente uma nova fração do espaço passa a sofrer as transformações necessárias para a produção de um trecho urbanizado de Cotia. Segundo CARLOS (2004:23)

...o acesso ao espaço na cidade está preso e submetido ao mercado em que a propriedade privada do solo urbano aparece como condição do desenvolvimento do capitalismo. A existência da propriedade privada significa a divisão e parcelarização da cidade, bem como a profunda desigualdade do processo de produção do espaço urbano que se percebe de forma clara e inequívoca no plano da vida cotidiana inicialmente revelada no ato de morar, que coloca o habitante diante da existência real da propriedade privada do solo urbano. O processo de fragmentação

\footnotetext{
${ }^{30}$ Dados retirados da Lei Complementar n. ${ }^{\circ}$ 001/91.

${ }^{31}$ Nascido em Cataguazes em 1902, o Sr. Niso Vianna, estabeleceu-se na cidade de São Paulo na década de 1930, tornando-se industrial do ramo de fertilizantes, uma década depois comprou na região de Cotia um sítio, a Granja Viana. Na década de 1950, realizou o parcelamento do seu sítio e fundou alguns bairros, faleceu em 1971 não vendo o "progresso" urbano da região.
} 
da cidade caminha junto ao processo de mundialização de forma contraditória. Homogêneo, a fragmentação do espaço da cidade também revela a hierarquização dos lugares e pessoas como articulação entre morfologias espacial e social...

Ainda nas décadas de 1940 e 1950 a Granja Viana teve parte do seu solo parcelado em grandes lotes para casas de veraneio, utilizados apenas como casa de campo visitado nas férias ou finais de semana prolongados, em forma de sítios ou chácaras, posteriormente os loteamentos foram tomando outra característica, a de moradia, então o espaço passa a ser tomado pela constituição dos bolsões e condomínios residenciais, segundo SEABRA (2004:196)

Os condomínios fechados surgiram inicialmente em cidades americanas. Em Los Angeles puderam se formar sem muros, com casas implantadas em amplos jardins, propondo continuidade de paisagens; elas próprias, sempre reconstruídas segundo o prazer estético em voga, como veiculou amplamente a indústria cinematográfica.

Em São Paulo os condomínios se multiplicaram nos últimos trinta anos, sempre como sinônimo de qualidade, de critério e de valor social. Mas aqui eles são fechados mesmo. O eixo São PauloCampinas está coalhado de condomínios, assim como em direção a Mairiporã e a Atibaia e em direção a Cotia, onde se estendem até São Roque.

A tentativa em tornar a região granjeira auto-suficiente, ou seja, uma região que funcione sem a necessidade do deslocamento de seus moradores até o centro de Cotia, constituído por bancos, comércios e afins, torna imprescindível considerar aqui a constituição do setor terciário, que é protuberante na região. Então se faz necessário saber que

...desde a grande atividade imobiliária que conduz ao parcelamento do solo para fins residenciais, até a instalação mais recente de equipamentos como o Colégio Rio Branco e diversas empresas avançadas em computação.

os clubes de campo servem ao lazer metropolitano e os serviços de gastronomia, que apontam para uma expansão e uma diversificação progressivas das atividades desse setor." (Lei Complementar 001/91 - II. 4. A participação do Setor Privado no Desenvolvimento de Cotia).

No fragmento espacial que compreende a região da Granja Viana foi promovido um espaço industrial, que dividiu a atenção e estímulo de capital com a promoção dos 
comércios, que nos últimos anos foi acrescido pelos prestadores de serviços, conduzindo a produção de um fragmento espacial regional de primeira grandeza, ou seja, foi criado um espaço com muito requinte e sofisticação para atender as necessidades de seus moradores granjeiros. Aliás, reforçando o primeiro capítulo deste trabalho, morar distante dos centros como a capital metropolitana modulando a atividade de morar é uma estratégia que segundo SEABRA (2004:196):

Trata-se de ações e projetos que se apresentam como necessários para proporcionar a evasão da cidade com muita idealização do bucólico, contra o universo concentracionista da cidade, contra o barulho e a fadiga, propondo o cultivo do seu próprio jardim, entre tantos outros apelos. Assim, os novos hábitos de morar tornavam-se realidade, de tal forma que o deslocamento da classe média para loteamentos residenciais foi natural e prazeroso, o que alimentado por um imaginário capaz de propugnar que a vida fora da cidade oferecia qualidade superior

Vemos a criação espacial de excelência sendo criado para os moradores da Granja Viana, contando com serviços de primeira necessidade como uma Sub prefeitura, dois Distritos Policiais, uma Unidade Básica de Saúde, uma agência do Correio e um Cartório Eleitoral (este é muito recente e foi concebido como uma "estratégia" municipal para que os moradores da Granja Viana sentissem-se estimulados à votar no Município), agências bancárias e ainda centros comerciais, conforme discutidos no primeiro capítulo.

A maioria dos moradores da Granja Viana possui sua vida profissional na cidade paulistana e nos finais de semana ainda recorrem à diversidade de entretenimento que a cidade de São Paulo pode oferecer, dando uma conotação de 'região' dormitório para a Granja Viana, remontando então à uma característica do município de 1717 , enquanto 'aglomerado de pouso'.

A Granja Viana não deve ser comparada a Alphaville ${ }^{32}$, onde os muros encerram não só os conjuntos residenciais como também as áreas de serviços e comércio, como se o próprio condomínio fosse transformado em uma "cidade autônoma". No entanto existe uma semelhança deste com a região granjeira. Como exemplo ilustrativo temos os múltiplos condomínios e bolsões residenciais 
...não equivale a uma pequena cidade. Aqui, não tem importância alguma que os indivíduos não se conheçam, porque o que os atrai é a vontade de separação, alimentada pela certeza de encontrar no vizinho um padrão aceitável, segundo certo ponto de vista. O lugar de morar corresponde a uma inserção social. Isso sabem perfeitamente os componentes da nova classe, que inclui as pessoas do espetáculo como são os jogadores de futebol, cantores e outros astros da mídia em geral. (SEABRA, 2004:198)

A cidade enquanto um espaço urbano é hoje profundamente marcada pela fusão da produção de fragmentos espaciais segundo os interesses e propósitos dos capitalistas, que utilizam-se de mecanismos públicos, como a normatização, para fazer valer as diferentes formas de usos e valores da terra urbanizada.

O espaço, enquanto resultado/meio do trabalho e da divisão social, e ao mesmo tempo condição para essa realização, nos fornece subsídios necessários para pensarmos a imagem da cidade num determinado tempo. Sua forma e conteúdo estão, tendencialmente, subjugados ao mundo do trabalho e da mercadoria, uma vez que

...o capitalismo parece esgotar-se. Ele encontrou um novo alento na conquista do espaço, em termos triviais, na especulação imobiliária, nas grandes obras (dentro e fora das cidades), na compra e na venda do espaço...(LEFEBVRE, 2002:143)

A mercantilização dos espaços "dentro e fora da cidade" mostra que o processo produtivo e a mais valia extrapolou as indústrias e invadiu o espaço social na criação de fragmentos espaciais, marcando um novo momento. Temos a valorização da terra segundo uma intencionalidade capitalista, num tempo onde o espaço é passível de ser comprado e vendido aos pedaços e que assume, portanto, a função de mercadoria que ganha valor no mercado imobiliário.

As dimensões espaço e tempo estão contidos na cidade. Entretanto não pretendemos aqui nos limitarmos ao espaço enquanto determinante de uma delimitação de território e ao tempo na sua perspectiva histórica. Tentamos mostrar com o desenvolvimento de diferentes espaços em diferentes momentos da economia de Cotia, a constituição de formas e conteúdos e o tempo enquanto conjunto de acontecimentos que servem ao sistema produtivo para reproduzir o capital.

Segundo CARLOS (2003:45)

\footnotetext{
${ }^{32}$ Alphaville é um condomínio localizado a aproximadamente 30 quilômetros da cidade de São Paulo em direção a Carapicuíba.
} 
A cidade enquanto construção humana, produto social, trabalho materializado, apresenta-se enquanto formas de ocupações. $O$ modo de ocupação de determinado lugar na cidade se dá a partir da necessidade de realização de determinada ação, seja de produzir, consumir, habitar ou viver.

A cidade, enquanto espaço construído na lógica capitalista, tem em cada parte uma finalidade, assim as formas vão transformando-se em funções, e o conteúdo dessas formas vai sendo tomado pelas representações que geram uma ocupação específica. Embora haja uma tendência a homogeneização, a fragmentação da cidade é bastante evidente, as formas, os conteúdos, e as funções vão sendo direcionadas e redirecionadas de forma incessante para um mercado específico.

Cotia, por meio dos empreendedores capitalistas, do poder público e até pela população foi produzindo ao longo do desenvolvimento de sua história fragmentos espaciais, urbanizando-as e tomando na sua totalidade a imagem de uma cidade cujo espaço é voltado para diferentes usos para a (re) produção do capital.

E nela encontramos processos que nos parecem válidos para muitas cidades. Se nos diferentes momentos históricos da cidade, como Cotia, por exemplo, tínhamos o espaço enquanto lugar da vida e das relações sociais, hoje o mesmo desbota-se e intensifica o valor do mercado e assim, as formas vão tomando o espaço de acordo com uma certa intencionalidade, muitas vezes implícita, mas que se revela na realização da ação, no descortinamento do conteúdo das formas.

As criações de diferentes fragmentos espaciais são resultantes de diferentes momentos em Cotia, é mais do que a somatória de várias épocas, cujos objetivos e estratégias imobiliárias vão sendo criadas de acordo com necessidades que embora sejam divergentes entre si, tenham algo em comum, todas elas trilharam o caminho que nos leva ao mercado, pois considerarmos que o espaço

...enquanto meio de consumo para satisfazer necessidades humanas, assume uma forma de valor, de intercambialidade; ele é trabalho materializado ou em potencial. Isso implica necessariamente uma disputa que obedece às regras do jogo de mercado. (CARLOS, 2003:80).

Entendemos que o valor da cidade, por meio de seus espaços, não é dado apenas pelo mercado ao apropriar-se e capitalizar a propriedade. A cidade ganha valor por meio da organização institucionalizada do Estado e ainda pela ação da sociedade 
civil que vive os espaços da cidade. Desta forma o meio torna-se ora condição ora condicionante para a organização e realização social, isto é, na articulação deste tripé é que a cidade ganha valor, funcionalidade e vida.

Há uma evidente e forte sobreposição do mercado sob os demais vetores, haja vista o fato de que todo espaço possui homogeneamente um valor que se diferencia entre si de acordo com a especificidade, aparato e geografia de cada porção vendável da cidade, remetendo à idéia de espaço citadino-mercadoria e, portanto à existência de cidadãos-consumidores, bem como a alteração do processo social, dizendo em outras palavras, se o espaço é construção da sociedade e foi transformada em mercadoria, esta sociedade não é mais constituída por outra coisa senão consumidores.

O espaço está todo "compartimentado" por meio do zoneamento institucionalizado pela prefeitura municipal de Cotia, mostrando um pouco as "marcas" da história da região cooptada pelo mercado, temos zonas mistas, industriais e estritamente residenciais, funções estas fáceis de observar no espaço granjeiro.

$\mathrm{Na}$ mesma região granjeira conseguimos identificar os diferentes espaços e classes sociais que vão tecendo uma malha urbana bem diferenciadas entre si, afinal

..Elas (as contradições) impõem, no âmbito do vivido, estratégias e lutas à sobrevivência no urbano porque, para permanecer habitante há que ser morador, há que ser aquele que usa, que delimita territórios de uso. Tanto que, à medida que a condição de pobre, como pobre urbano se definia, entre os ricos criou-se a necessidade de administrar a separação, aqui identificada como auto segregação... (SEABRA, 2004:183)

A divisão social do trabalho reflete-se no espaço por meio da estratificação. Encontramos na cidade não só as finalidades na realização de determinada ação, mas também aqueles espaços direcionados às indústrias, consumo ou moradia, mas dentro de cada especificação há ainda uma redefinição quanto ao público, alvo consumidor de cada qual. Os espaços são beneficiados (infra-estrutura, localização e outros) ou não, o que resultará em valores diferenciados e, portanto, no acesso ou não de determinada população no uso/consumo daquele espaço da cidade.

...Não há espaço, em uma sociedade hierarquizada, que não seja hierarquizado e que não exprima as hierarquias e as distâncias sociais, sob uma forma (mais ou menos) deformada e, sobretudo, dissimulada pelo efeito de naturalização que a inscrição durável das realidades sociais no mundo acarreta: diferenças produzidas 
pela lógica histórica podem, assim, parecer surgidas da natureza das coisas.... (BOURDIEU, 1999: 160).

As diferenças da hierarquização social, promovidas na constituição do espaço produzido com todas as diferenças dadas pela maior aplicação do capital ou não, responde por uma estratégia capitalista na perpetuação da (re) produção capitalista. Esta estratégia está de tal modo incorporada pela sociedade que essas diferenças são admissíveis e tidas como naturais. É "natural" - dentro da lógica capitalista - que um determinado espaço investido de infra-estrutura tenha um valor maior e, portanto, direcionado a uma determinada classe social.

A produção espacial, a constituição do urbano e a configuração da cidade e de toda a racionalidade empregada nela produzem e permitem o aceite social de signos, regras, condutas e valores forjados na ideologia e sua materialização no espaço. Afinal, ao portar-se enquanto mercadoria, o espaço incorpora cada vez mais "novas" funções que são tomadas impetuosamente por imagens e representações direcionados para o consumo. Desta forma

..la propaganda (política) y la publicidad (comercial) utilizan o construyen representaciones que remplazan a las "cosas" y a la "gente". El político no se limita a cuidar su "imagen de marca"; la produce, la mantiene, ayudado por especialistas de la mercadotecnia. Asimismo, el "vendedor" no sólo produce la imagen del producto sino las "necesidades" y las "motivaciones. ${ }^{33}$ (LEFEBVRE, 1983:32)

O espaço da cidade enquanto produto, imbuído de um valor e exposto no mercado imobiliário como uma "coisa" produzida ou ainda reproduzida numa escala industrial é colocado à venda para os consumidores em potencial. Como não predomina mais a necessidade negada ao uso, as pessoas não consumiriam esse espaço se um desejo tornado necessidade de consumo não fosse criado. Elas têm que se sentir "motivadas" na aquisição de um bem.

Ao mesmo tempo em que a mercadoria está sendo criada, há estratégias para a realização do mercado no que diz respeito à criação de um mercado para o produto criado. O discurso empregado para conduzir o consumidor em potencial para a compra

\footnotetext{
33 Tradução da autora "..a propaganda (política) e a publicidade (comercial) utilizam ou constroem representações que trocam as "coisas" e as "pessoas". O político não se limita a cuidar de sua "imagem marca"; ele a produz, a mantêm, ajudado por especialistas de mercadotecnia. Assim mesmo, o "vendedor" não só produz a imagem do produto como as "necessidades" e as "motivações"."
} 
do espaço visa não só despertar o interesse como legitimar o desejo do consumo tornado naturalizado ${ }^{34}$.

Os espaços são projetados para, na maioria das vezes, atender ao objetivo de atrair os indivíduos, não enquanto cidadãos, mas como consumidores. Há um investimento inicial para produzir o espaço, a edificação, a infra-estrutura que acabam definindo o seu consumidor final. Não podemos nos esquecer que os fatores dados pelo capital e pela dominação estão presentes na sociedade o tempo todo.

O que, em nosso tempo, seja talvez o traço mais dramático é o papel que passaram a obter, na vida cotidiana, o medo e a fantasia. Sempre houve épocas de medo. Mas esta é uma época de medo permanente e generalizado. A fantasia sempre povoou o espírito dos homens. Mas agora, industrializada, ela invade todos os momentos e todos os recantos da existência ao serviço do mercado e do poder e constitui, juntamente com o medo, um dado essencial de nosso modelo de vida." ( SANTOS, 1998:23)

A comercialização de espaços faz uso de um marketing, logo ele passa pela ideologia, pelas representações que vão justificar o consumo de um dado espaço. Hoje em dia quem não gostaria poder morar num belo condomínio fechado arborizado e salvo do stress promovido pelo ritmo de fluxos da cidade? Qual empresa não gostaria de estar estabelecida no espaço de primazia global no espaço da cidade? Será que não haveria indivíduos ${ }^{35}$ que gostariam poder ser proprietários de um pedacinho da cidade, mesmo que este não apresentasse benefício/infra-estrutura para moradia? Parecem tão "naturais" essas necessidades na sociedade que as respostas giram em torno da propriedade privada enquanto um bem necessário para a reprodução da vida.

Temos por meio dos códigos, na emissão da informação, na circulação das notícias, a criação de acontecimentos que tendem a homogeneizar o comportamento, mobilizando a sociedade e moldando um padrão de consumo imensurável. Não estamos dizendo aqui das formas que induzem o comportamento, mas dos acontecimentos enquanto novidades que promovem o surgimento das formas.

Assim, segundo SANTOS (1998:21) "Diante de nós, temos, hoje, possível (e freqüentemente), com a falsificação do evento, o triunfo da representação sobre a

\footnotetext{
${ }^{34}$ A idéia de consumo tornado naturalizado faz menção a um consumo que parece ser instintivo, espontâneo enquanto tendência natural do homem, sem artifício ou interferência social para que se dê o ato.

${ }^{35}$ Principalmente os que estão despossuídos de tudo na cidade.
} 
significação...". Os acontecimentos são incorporados pela ideologia de forma a espetacularizá-lo e fundamentá-lo em meio à sociedade obtendo um efeito social que promoverá o consumo do espaço por meio das representações que despertam e manipulam o desejo na sociedade e naturaliza-o como necessidade.

Seja por meio da necessidade do cultivo para subsistência ou comercialização da primeira fase de Cotia, criando determinados espaços ou depois, com a discutida criação do espaço industrial e o desenvolvimento residencial de alto padrão da Granja e a respectiva produção espacial para que houvesse a demanda e a procura no mercado imobiliário, o fato é que em detrimento da (re) produção capitalista, seja a nível empresarial ou somente enquanto atividades que gere um acréscimo à receita municipal de Cotia, muitas representações permearam as decisões que modificaram o espaço local. Afinal

...O espaço foi tomado e moldado a partir de elementos históricos e naturais, mas esse foi um processo político. O espaço é político e ideológico. É um produto literalmente repleto de ideologias. (LEFEBVRE In: SOJA, 1993:102).

Desta forma, a cidade foi capturada pelo mercado, mas possui, enquanto possibilidade, a sua própria superação. O tempo e seus processos que tomam forma no espaço permitem não só os seus desdobramentos, como rupturas e descontinuidades. Temos um "vir a ser" constante na cidade.

Para trabalharmos a idéia de (re) produção do espaço e representação social, não basta pensarmos somente em espaço e tempo, mas concomitantemente nas dimensões global e local, as reconfigurações das relações dessas esferas dadas pelo neoliberalismo, enquanto necessidade que determina uma funcionalidade dos lugares da cidade pela sua raridade.

A Região da Granja Viana assim é descrita no Guia Turístico Oficial distribuído pelo departamento de Turismo do município:

A Granja Viana é um bairro nobre com $50 \mathrm{~km}^{2}$ de área e aproximadamente 50.000 habitantes, sedia uma infra-estrutura residencial de alto nível, condomínios de luxo, e $75 \%$ do parque industrial cotiense (alimentação, auto peças, metalurgia, serigrafia, informática, químicos, têxteis, serviços, madeiras, plásticos, etc.)...O bairro também é conhecido por residirem nele 
Artistas Plásticos e Intelectuais famosos, gente da comunicação e da Música. (COTIA, 2004:32)

A Granja Viana, embora seja uma única região dentro da cidade de Cotia, é marcada por vários espaços que são distintos entre si, e, dependendo do foco que vamos analisá-la, se for o tradicional e a modernidade como veremos no próximo capítulo, vamos analisar a região recortada em alguns espaços que se diferem dos espaços observados se o foco for às classes sociais, como pretendemos fazê-lo neste capítulo ainda.

Ainda em 1939, quando o Sr. Niso Viana comprou uma propriedade e junto com a sua família explorou a região por meio da agropecuária, a terra nesta fase ainda cumpria com uma função, o capital era obtido pela terra, pelo uso da terra. Foi em 1951 que esta mesma terra tornou-se mercadoria, ela não era mais o meio para obter o capital, mas o próprio capital. Nesta época não só o Sr. Niso, como outros detentores de terra na região fizeram talvez o que seria o primeiro parcelamento com a finalidade de comercializar o espaço da Granja. Houve até uma tentativa de organizar este espaço, com o objetivo de "tornar o lugar urbano" por meio da criação de núcleos residenciais com uma óbvia hierarquização espacial. Desta forma

Niso loteou duas áreas distintas, as áreas nobres, vendidas como chácaras para amigos Rotaryanos que construíram casas de campo (Hoje é área formada por 4 vias principais: Av. São Camilo, Av. José Félix de Oliveira, Cherubina Vianna e suas transversais) e loteou áreas menores para os empregados que eram vendidas à estes por valor baixo e à longo prazo (toda a região onde hoje estão situadas a Telesp, delegacia, guardas rodoviários...). (www.granjaviana.com.br fevereiro/2004)

Curiosamente os espaços divididos mantêm a sua lógica de valor até os dias de hoje. Há nestas quatro vias principais mencionadas, enquanto áreas nobres, a criação de uma centralidade que guarda um alto valor ainda, e nas áreas menores que na época foram loteadas para os empregados, há um valor inferior (se comparado com as demais áreas granjeiras). Esta divisão do espaço da Granja, em grandes e valiosos lotes em detrimentos dos lotes menores e de valor menor ajudou a configurar uma situação não só de hierarquia, mas de desigualdade social. 
Observando os espaços (ver pág. 46 A), conseguimos "ler" as morfologias e classificar a região da Granja Viana em três distintos núcleos, capturando a auto segregação socioespacial. São eles, seguindo a direção São Paulo- Interior:

a) Do lado direito da rodovia Raposo Tavares temos como marco a "Capela de Santo Antonio" e mais recentemente (nas últimas quatro décadas) um pequeno centro comercial paralelamente à rodovia, encontramos nas ruas vicinais e a própria Av. José Félix de Oliveira e a Av. São Camilo, o centro mais antigo granjeiro e as vias de acesso aos bolsões e condomínios residenciais de maior porte, a "ilustre" Granja Viana está praticamente encerrada neste espaço;

b) Do lado esquerdo da rodovia Raposo Tavares quase que defronte a Granja Viana antiga, temos um segundo núcleo denominado Jardim da Glória. Este tem logo nas ruas principais de acesso um "centrinho" comercial de estilo, a entrada de um único bolsão residencial de grande porte, mas depois o bairro divide-se em Jardim Cantagalo, Galo Branco, Olaria e Jardim do Engenho (deste existe a favela do "Copo Sujo") e Moinho Velho. Todos esses bairros demonstram uma realidade econômica muito diferente da Granja antiga; são constituídas por casas populares, casas auto-construídas, casas em áreas ocupadas ("invadidas segundo a administração pública) e comércios de bairro mais simples (bares, armazéns, lojinhas de "1,99", por exemplo).

c) Novamente do lado direito da rodovia Raposo Tavares, depois de passar pela capela, rodando uns $500 \mathrm{~m}$ pela rodovia sentido interior, avistamos o bairro Parque São George, embora voltado para uma população de baixa renda (salvo um ou outro condomínio e bolsão residencial de nível médio "perdido" nesses espaços), encontramos muitas casas populares e comércios locais pouco diversificados. A subprefeitura da Granja e a Delegacia de Polícia Civil ficam neste bairro.

d) No Km 21 há as favelas "do Chiclete", "do Cristo" e um bairro também pobre chamado Recanto Suave. Esses não são considerados 
e nem se consideram pertencentes à Granja Viana, entretanto eles são "geograficamente" granjeiros, mas quando questionados sobre onde moram, respondem que moram na favela ou no Recanto Suave, desconhecendo sua condição de granjeiro.

Mesmo entre os dois bairros populares que se reconhecem fazendo partes da Granja encontram diferenças sociais: o Jd. da Glória (espaço mais industrializado) expressa uma tentativa de ser mais sofisticado do que o Parque São George.

Vale a pena apontar aqui que embora o Jd. da Glória e o Parque São George sejam igualmente destinados à população de renda baixa, pudemos notar pelo estudo de campo, que o segundo bairro parece ser mais carente que o primeiro. Mais adiante tentaremos acenar as diferenças.

A Granja Viana contempla em seu espaço três áreas distintas entre si, como se fossem regiões que estivessem desvinculadas, cada qual com seu comércio próprio, com uma vivência própria do espaço. Não compartilham a região como um todo, é como se o "efeito" que separa a Granja Viana de Cotia, se repetisse de igual forma entre a Granja Viana, o Jd. da Glória e o Parque São George.

De um lado temos a Granja Viana vendável, cuja imagem é a mais divulgada, e do outro temos bairros, que constituem a Granja Viana, mas que não são reconhecidos como tal, eles são tão diferentes aos granjeiros da Granja "comercializada" quanto o resto do município de Cotia, mas e, no entanto, todos moram, ao menos formalmente do ponto de vista administrativo, na Granja Viana.

Tentamos analisar essas diferenças pelas construções das casas e dos comércios, além de entrevistas com os moradores/trabalhadores. A pesquisa de campo nos proporcionou um enriquecimento maior do que o esperado, foi possível perceber durante o contato com alguns moradores e trabalhadores da Granja a forma como os diferentes se completam. A prepotência da Granja estilizada em suntuosas construções ou no melhor do paisagismo foi flagrada durante as fotos em meio a interrupções de seguranças que ora educados, ora autoritários e irônicos deixavam claro o incômodo da "central de segurança local" com a aproximação do "desconhecido". Inicialmente vamos mostrar uma Granja Viana "vendida" e reconhecida pela capital metropolitana, a região 
exuberante, requintada, global e rupestre, cujas formas e signos vão dando vida a região.

Vamos iniciar pela venda da Granja. Além do site da Granja (www.granjaviana.com.br) onde é possível ver alguns anúncios de casas à venda na Granja Viana (área nobre) por meio de um ícone escrito "imóveis", há outdoors espalhados no trecho da rodovia Raposo Tavares considerado Granja, junto à algumas imobiliárias igualmente no entorno da rodovia, com o intuito de despertar o possível interesse dos usuários da rodovia. O apelo dos outdoors, como já dissemos é entorno do verde, mas há um que nos chamou bastante a atenção, que remete ao "modo de vida americano" no seu teor mais apelativo ao consumo, ele mostra um determinado residencial fechado do alto padrão na região chamado "Bervely Hills."
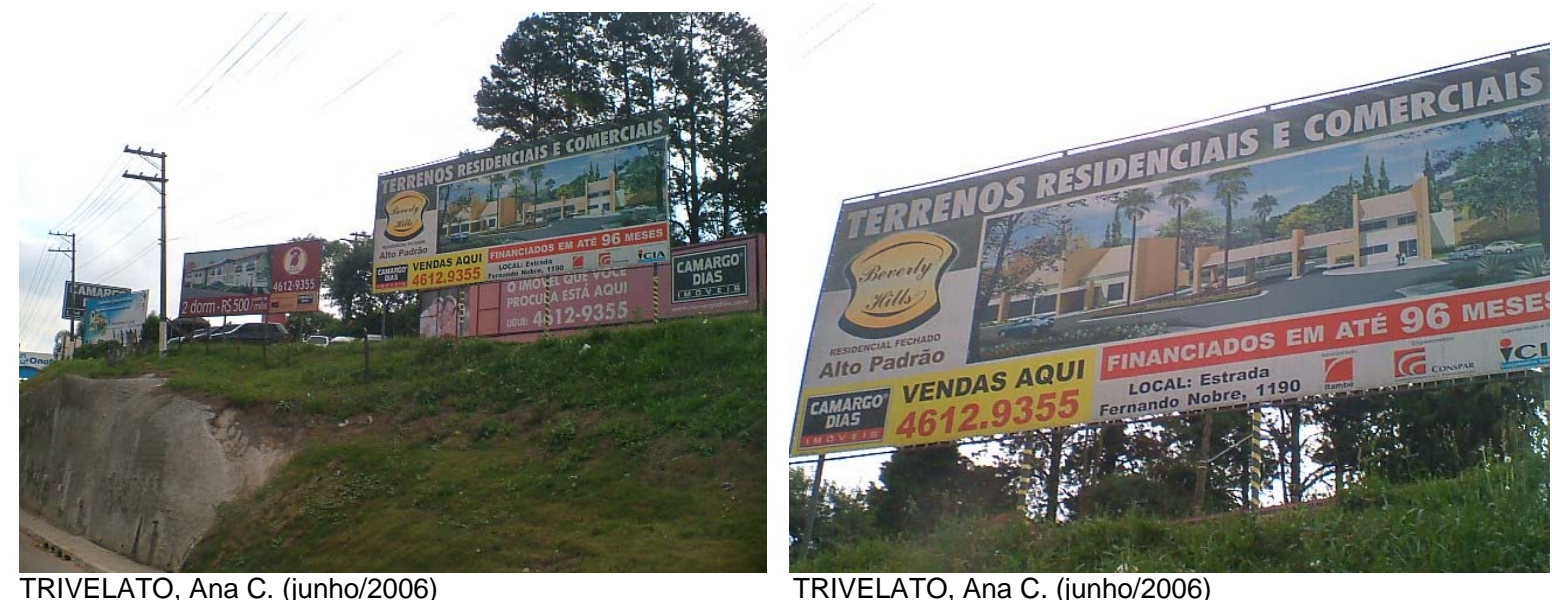

TRIVELATO, Ana C. (junho/2006)

Outdoors da rodovia raposo Tavares "vendendo" espaços nobres da Granja Viana.

A oferta de casas e terrenos em outdoors tem como reforço a "passagem pela Granja Viana", ou seja, no momento em que as pessoas de dentro do seu automóvel avistam a Granja, geralmente reconhecido como apenas um trechinho da rodovia $(\mathrm{Km}$ 23 à 24,5 da Raposo Tavares), a percebe como um lugar provido de muita limpeza e bom gosto nas lojas constituintes do centro de consumo paralelo à rodovia.

Não são apenas os condomínios, mas o comércio que serve estes condomínios que gera um marketing de segurança ou bom gosto, há uma aparente escolha das lojas que compõem o centro de consumo dirigido aos moradores dos condomínios (em nosso caso, bolsões residenciais também), que mantêm um padrão metropolitano: é como se o que estivesse sendo oferecido fosse a extensão do lugar onde o usuário vive, existe o estilo da região promovendo um bem-estar aos mesmos (os aí residentes) e que talvez 
seja justamente por este motivo que esteja reforçado a auto-segregação. O espaço e tudo o que ele contêm tem as características de um determinado tipo de consumidor/morador, portanto outras pessoas que não tenha o mesmo perfil não se sentiriam a vontade em "consumir/usar" o espaço e tudo o que ele possa oferecer.

Existe um "pacote" de elementos que "enchem" os olhos de um "comprador" em potencial: são os condomínios, os comércios, os prestadores de serviços, o paisagismo e até a limpeza local. Existem garis que são responsáveis em limpar toda a via paralela à rodovia (já que muita gente ainda "arremessa" "lixo" de seus automóveis quando ainda em movimento). Toda a Granja nobre tem suas vias limpas.

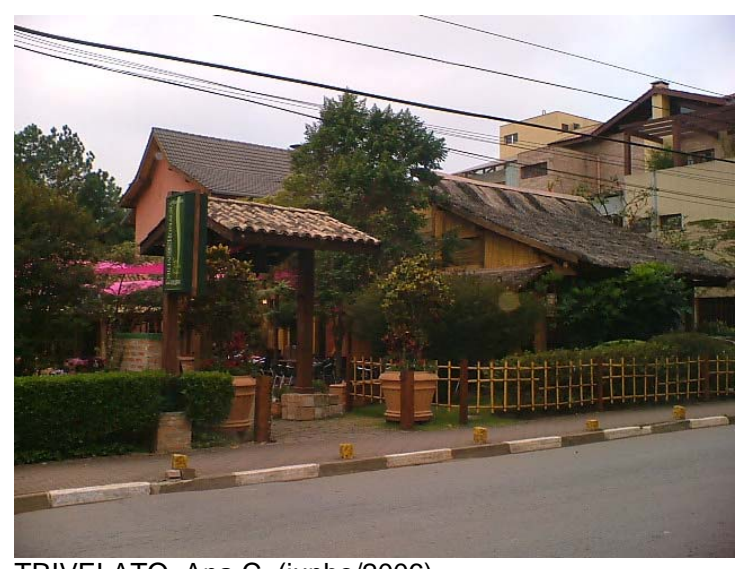

TRIVELATO, Ana C. (junho/2006)

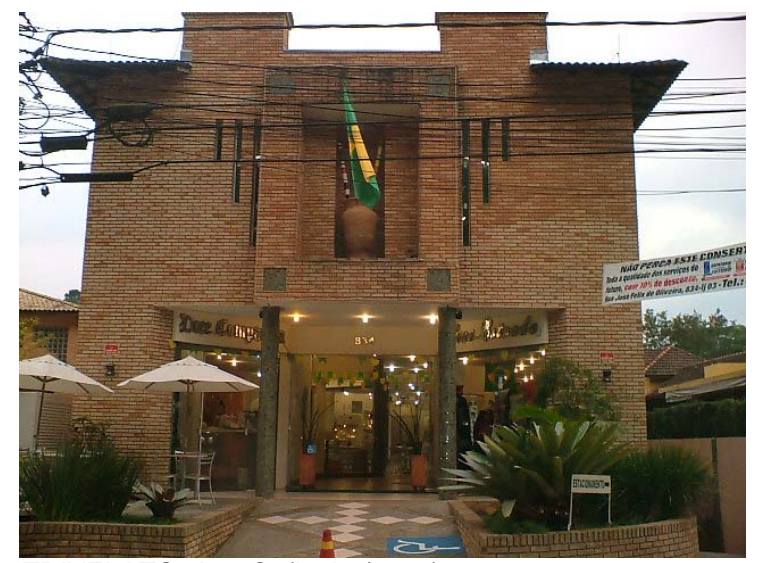

TRIVELATO, Ana C. (junho/2006)

As duas fotos acima retratam o comércio da Rua José Félix de Oliveira.

O estilo, a forma e os produtos (com a qualidade oferecida na Granja) não são encontrados em outro lugar que não seja na Granja Viana nobre. Nela existe a divulgação de uma imagem de requinte e bom gosto que permeia as avenidas mais antigas, por um motivo muito simples: são elas que dão acesso aos condomínios e bolsões residenciais de grande porte. Aparentemente tudo é estrategicamente pensado sob a lógica da reprodução do capital. 


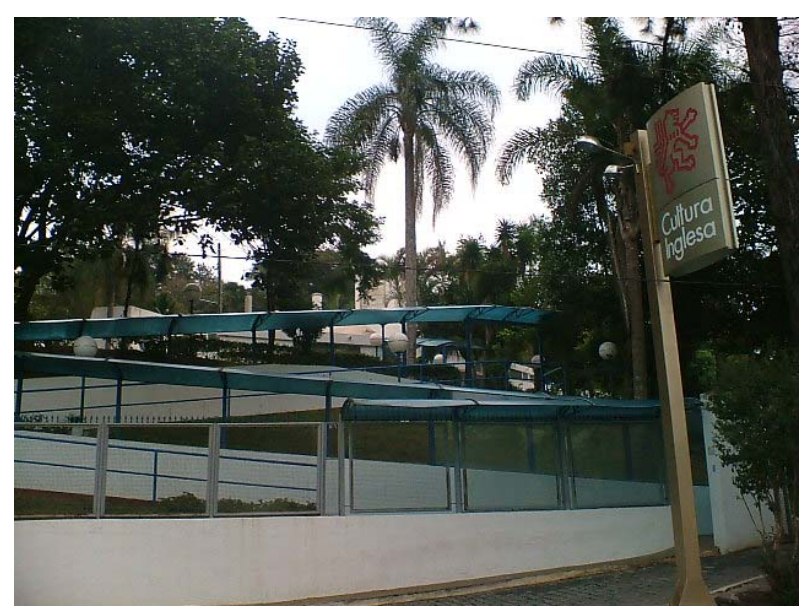

TRIVELATO, Ana C. (junho/2006)

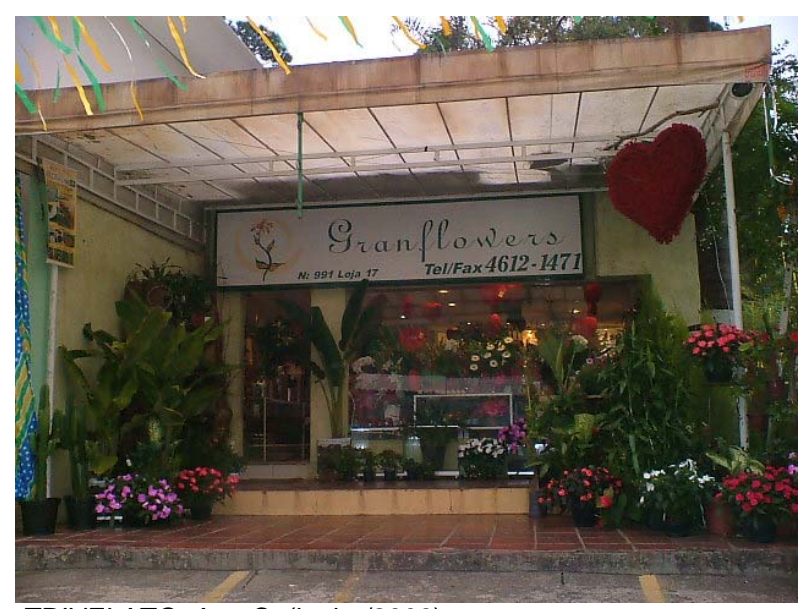

TRIVELATO, Ana C. (junho/2006)

As fotos acima mostram fachadas de prestadores e comércios da Rua José Félix de Oliveira.

Não podemos nos esquecer que "... As diferenças que emergem e se instauram no espaço não provêm do espaço enquanto tal, mas do que nele se instala, reunido, confrontado pela/na realidade urbana..." (LEFEBVRE, 2002:117). De certa forma, o valor é agregado ao espaço à medida que o verde - paisagístico (utilizado pela mídia para valorizar o espaço) divide o espaço com os comércios e os prestadores de serviços locais.

Aliás, o interesse na infra-estrutura predial e provimento da Granja de comércios e serviços é bem mais forte do que a "preocupação" com o ambiente. O que estamos chamando aqui de centro de consumo (referindo-se à formação paralela a rodovia Raposo Tavares) é chamado pelos granjeiros de Boulevard Granja Viana, que está construído sobre um córrego que foi canalizado bem como foi aterrada toda a área de "banhado" para a constituição do centrinho.

Caminhando pela rua José Félix de Oliveira notamos algo - ambientalmente contraditório também: há um prestador de serviços para retirada de terra e entulhos nesta rua. A fachada do estabelecimento é muito bonita, paisagisticamente equilibrada, calçadas e estacionamento limpo e um escritório grande e arejado por grandes portas e janelas: é o "Serginho da Terra", tudo realmente de muito bom gosto. No entanto, há aproximadamente uns $300 \mathrm{~m}$ de distância há um córrego que corta esta rua (uma rua comercial muito bonita e limpa), mas o córrego está muito sujo, não só as águas com resíduos "atolados" na sedimentação do leito como também no entorno (na sua área de proteção), tudo muito sujo e uma caçamba do "Serginho da Terra" bem ao lado, como se fosse um grande cesto de lixo bem ali, encostado ao córrego. Compreendemos está 
relação como a sujeira "escondida" embaixo do tapete, imperceptível, mas denunciado pelo volume "discreto" sob a cobertura.

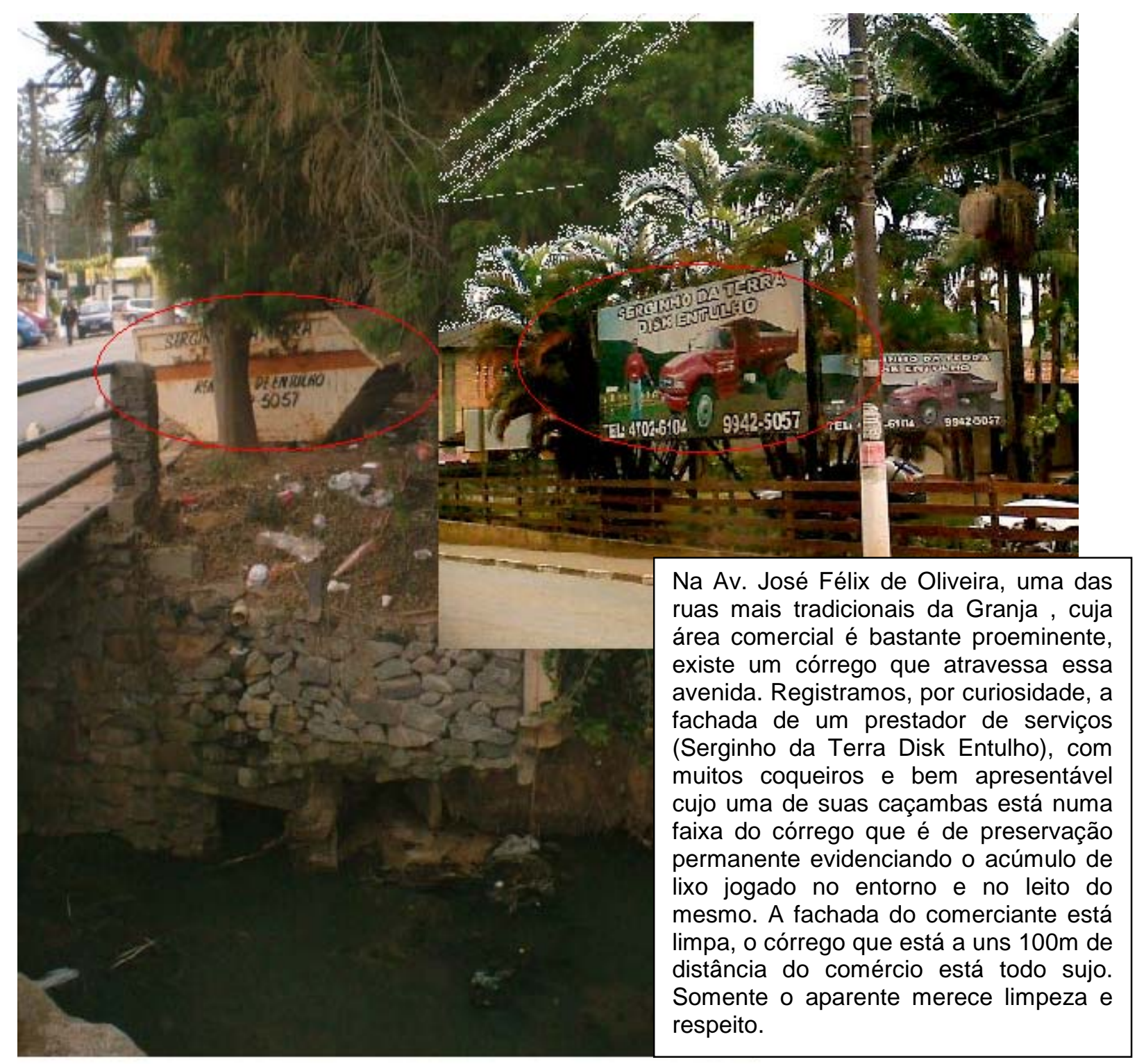

TRIVELATO, Ana C. (junho/2006)

Assim:

O modo de produção capitalista produz um espaço como todo modo de produção. Mas aqui a produção só ocorrerá se permitir a valorização do capital. Na produção do espaço há algo mais, um lado estratégico e político de grande importância, pois não é uma produção qualquer. Acrescenta algo decisivo a essa produção, posto que é também reprodução das relações de produção (CARLOS, 2003: 76) 
A "explicação" para a constituição do espaço granjeiro está no modo de produção capitalista, a produção de um espaço "nobre" garante a reprodução do capital e também caracteriza a fragmentação espacial como forma de "raridade" seja pelo modo de viver junto à natureza (mesmo que na aparência, já que estamos tentando evidenciar que na Granja temos quase como "regra" uma natureza manejada por meio de trabalhos paisagísticos ou violentada em nome do desenvolvimento e bem-estar social), ou seja, pelo valor "abaixo da tabela" se comparado com alguns condomínios/residenciais da metrópole paulistana..

O exposto por CARLOS nos ajuda a entender também uma Granja fragmentada, interelacionada, é bem verdade, mas dispare. Vejamos algumas comparações com o intuito de capturamos a contradição existente entre a Granja Viana, o Jardim da Glória (vamos aqui trabalhar com todos os bairros: Jd. Cantagalo, Galo Branco, Olaria, Jd. Moinho Velho, como todos pertencentes ao Jardim da Glória) e o Parque São George.

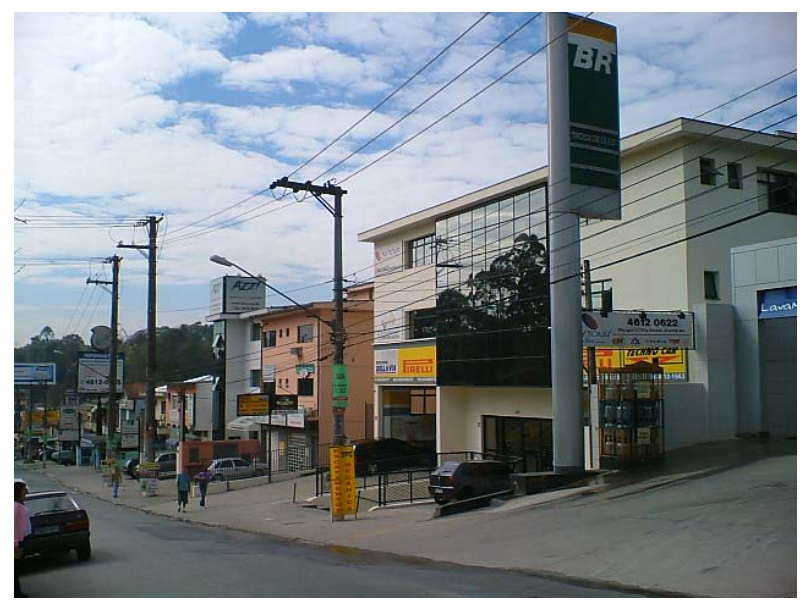

TRIVELATO, Ana C. (junho/2006)

Foto da Av. dos Manacás

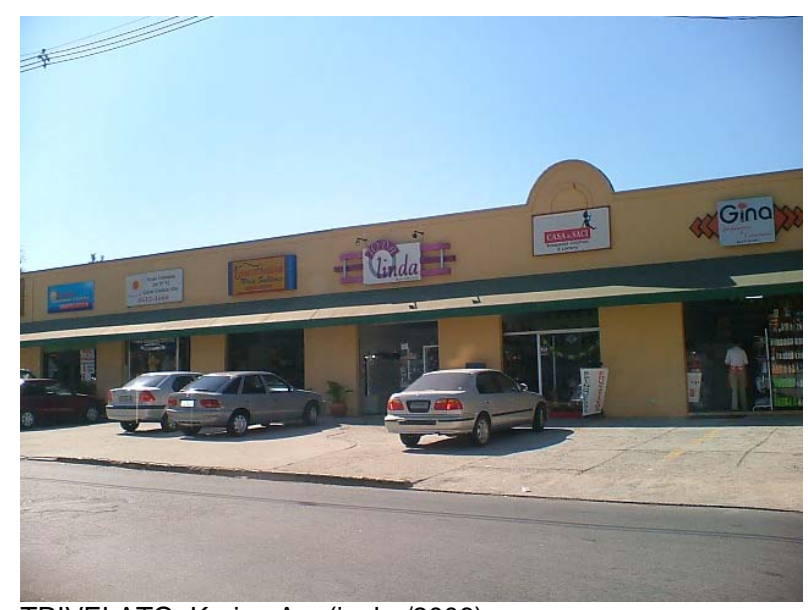

TRIVELATO, Karine Ap. (junho/2006)

Foto da Av. João Paulo Ablas

Nas fotos acima temos o Jd. da Glória: A primeira avenida fica paralela à rodovia Raposo Tavares (sentido interior-São Paulo) e a segunda é a que dá acesso imediato da rodovia ao Jd. da Glória, nelas (a primeira em toda a sua extensão e na segunda, logo no início dela) estão os comércios cujas fachadas são as mais "bonitas", lembrando um pouco as fechadas comerciais da Granja antiga (rica), vale a pena notar a limpeza das calçadas e das ruas. 


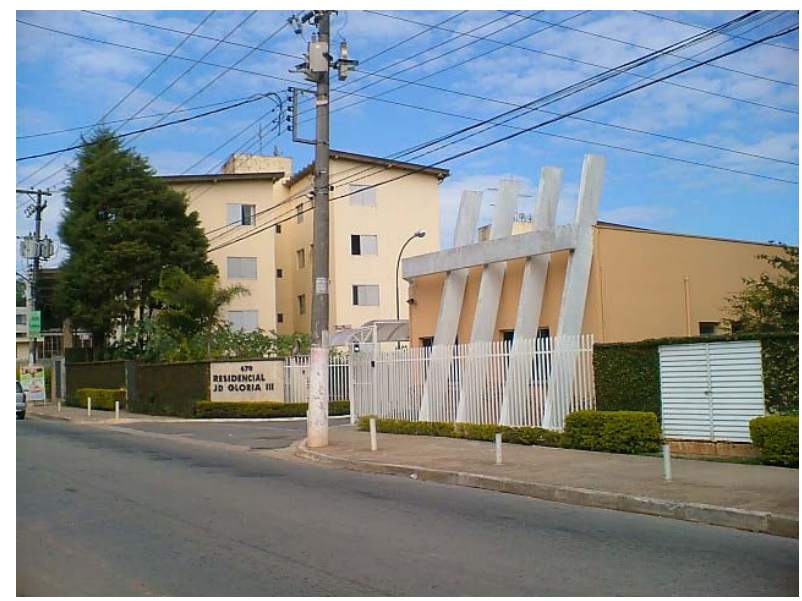

TRIVELATO, Ana C. (junho/2006)

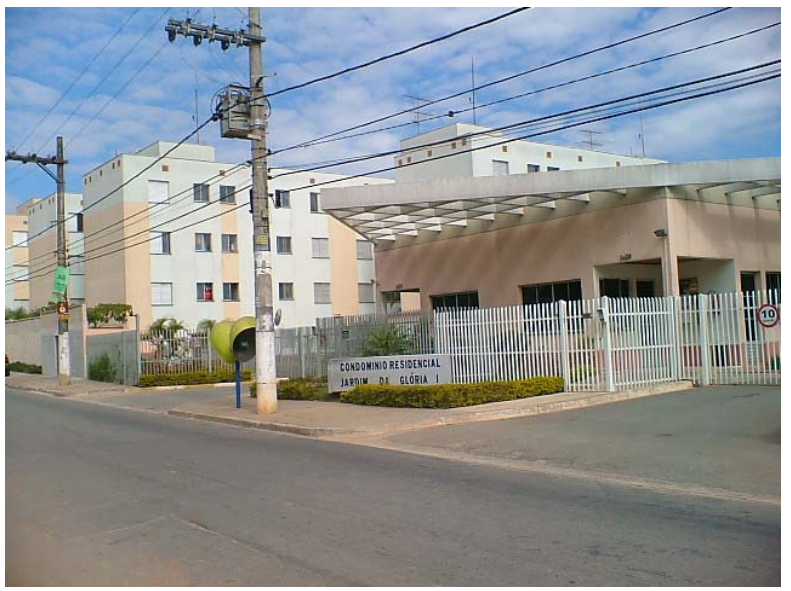

TRIVELATO, Ana C. (junho/2006)

As fotos acima mostram dois Conjuntos Residenciais localizados à Av. João Paulo Ablas.

O Jardim da Glória tem um grande número de Conjuntos Residenciais verticalizados, como podemos observar. São prédios simples com apartamentos "aparentemente" pequenos ${ }^{36}$, o valor aproximado é de $\mathrm{R} \$ 70.000,00$ (informação coletada na portaria - onde existia uma placa de "vende-se um apartamento").

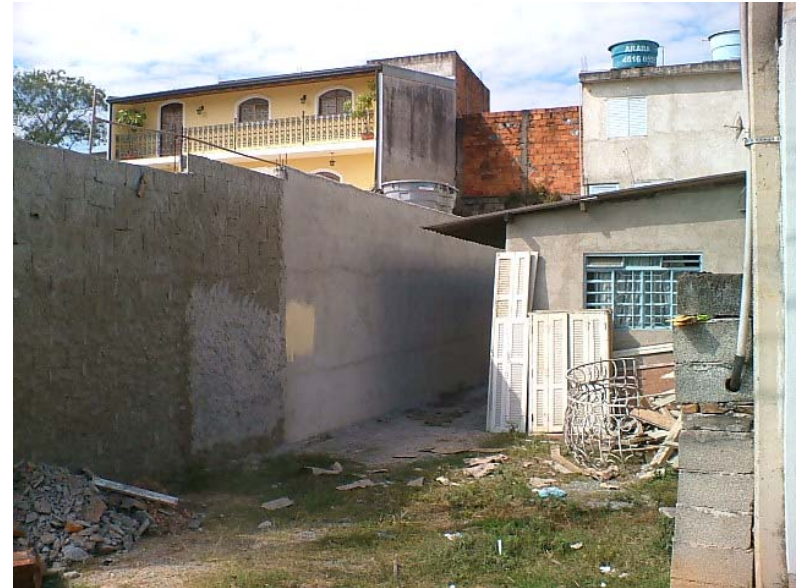

TRIVELATO, Ana C. (junho/2006)

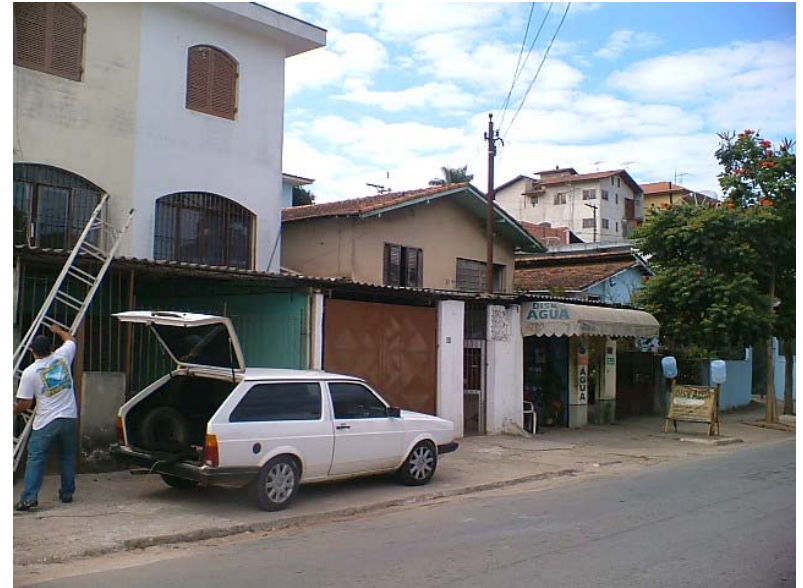

TRIVELATO, Ana C. (junho/2006)

As fotos acima mostram casas do Jardim da Glória, respectivamente da: Rua dos Esquilos e Avenida João Paulo Ablas.

As contradições estão bem ao lado uma da outra. Temos casas auto construídas de pequeno porte ao lado de casas maiores terminadas, ou casas de construtoras (geminadas) ao lado de casas e casebres antigos, cujas garagens foram transformadas em pontos comerciais para ajudar na renda familiar.

\footnotetext{
${ }^{36}$ De acordo com a portaria do Residencial Jardim da Glória III, os apartamentos têm $42 \mathrm{~m}^{2}$. (Informação obtida em junho de 2006).
} 


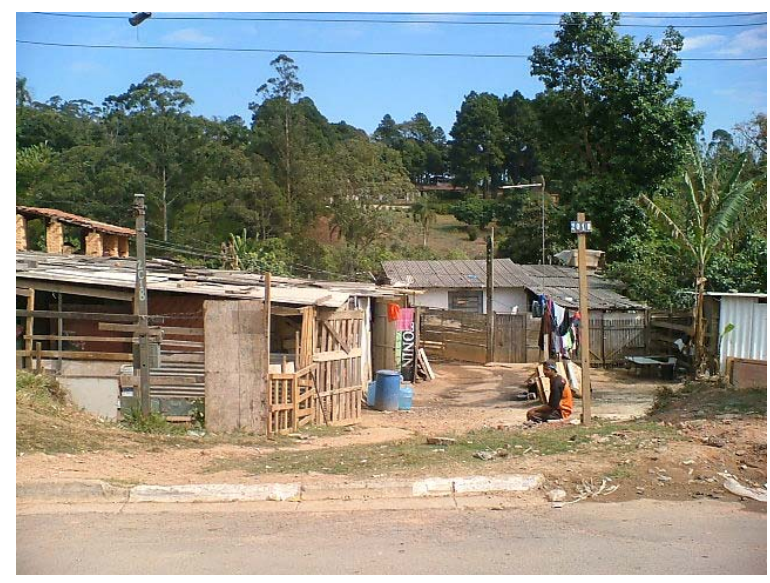

TRIVELATO, Ana C. (junho/2006)

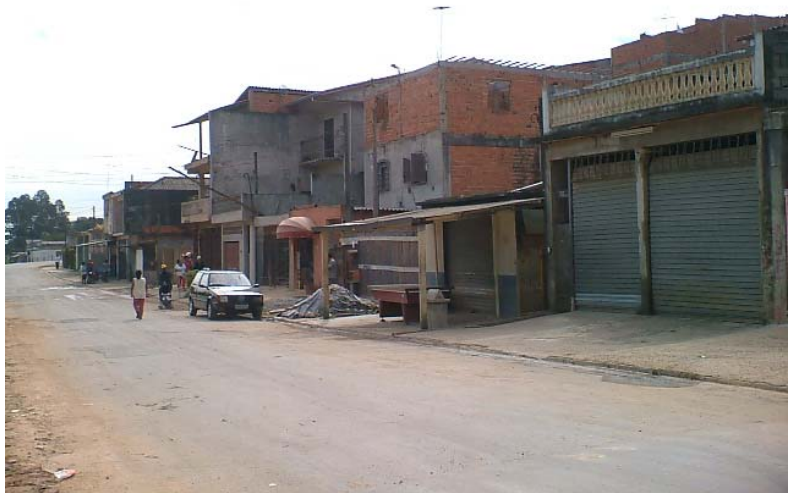

TRIVELATO, Ana C. (junho/2006)

As fotos acima mostram áreas ocupadas ilegalmente na Olaria - Jardim da Glória.

Essas fotos retratam a Granja Viana que a gente não conhece aqui: é o Jardim da Olaria (no canto esquerdo acima da primeira foto, vemos construções antigas da atividade realizada no espaço já há algum tempo atrás). O bairro é considerado pertencente ao Jardim da Glória, embora sejam barracos e casas auto construídas cujas fachadas não lembram em nada aquilo que costumamos ver como Granja Viana. Podemos notar que as calçadas e as ruas também são limpas e há a presença da vegetação.

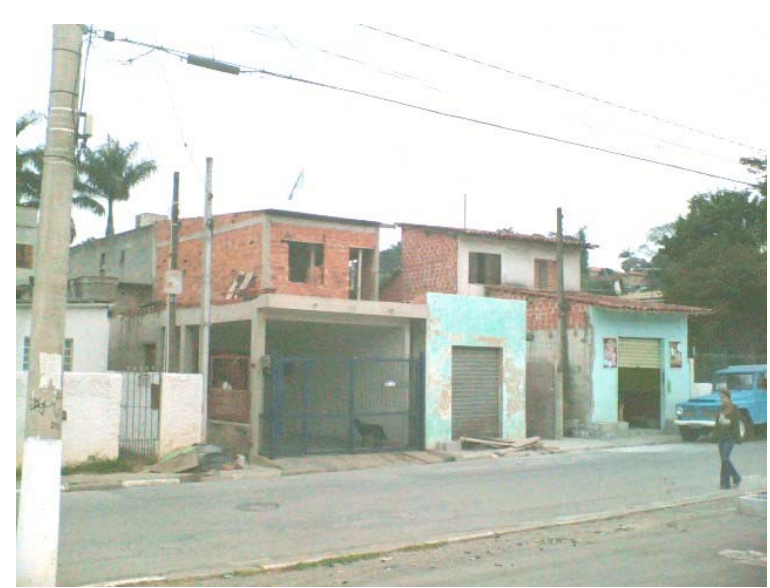

TRIVELATO, Ana C. (junho/2006)

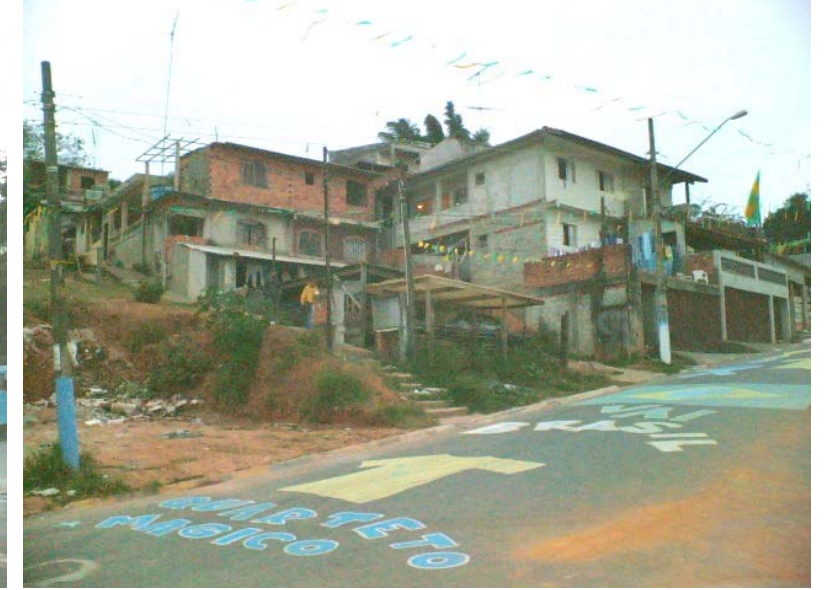

TRIVELATO, Ana C. (junho/2006)

As fotos acima mostram duas casas do Parque São George, respectivamente na Av. Denner e vicinal da Rua Direita.

No Parque São George predominam as casas auto-construídas e visitando o local foi possível observar como "tendência" a transformação das garagens em 
pequenos pontos comerciais, o que evidentemente auxilia na renda familiar. Foi possível perceber também a diferença quanto a limpeza do espaço público entre o Parque São George e o Jardim da Glória.

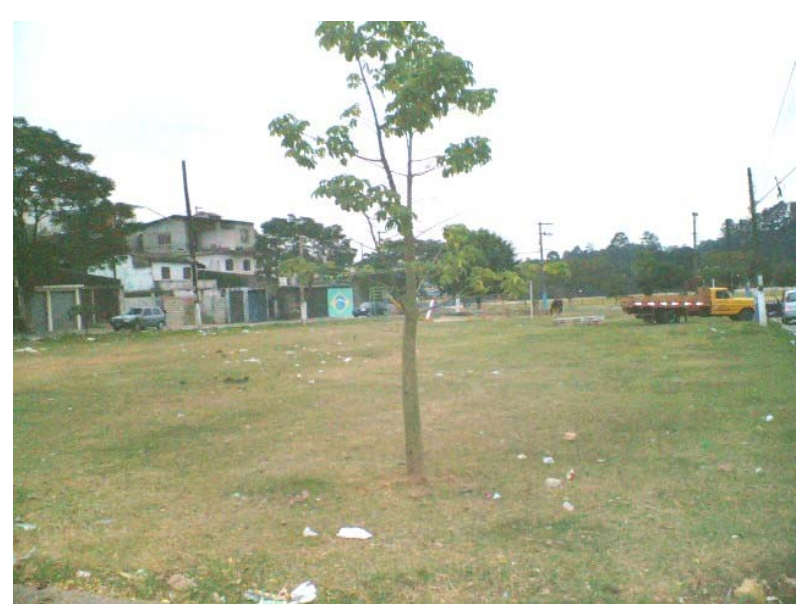

TRIVELATO, Ana C. (junho/2006)

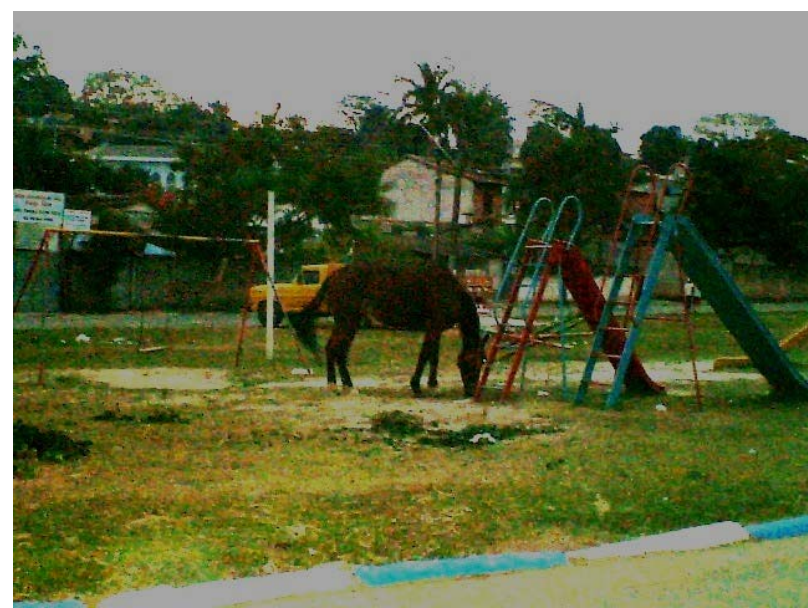

TRIVELATO, Ana C. (junho/2006)

As fotos mostram um mesmo parque público - área verde para lazer - na Avenida Central do Parque São George.

Existem espaços de lazer público no bairro do Parque São George, mas a sujeira e a presença de animais no playground (os "possíveis" carrapatos do cavalo poderia facilmente transmitir doenças às crianças que fizessem uso deste espaço).

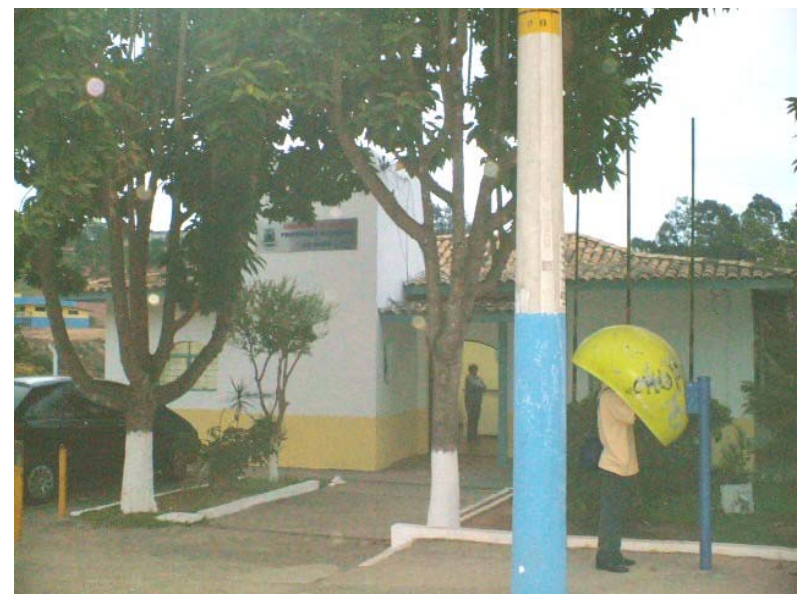

TRIVELATO, Ana C. (junho/2006)

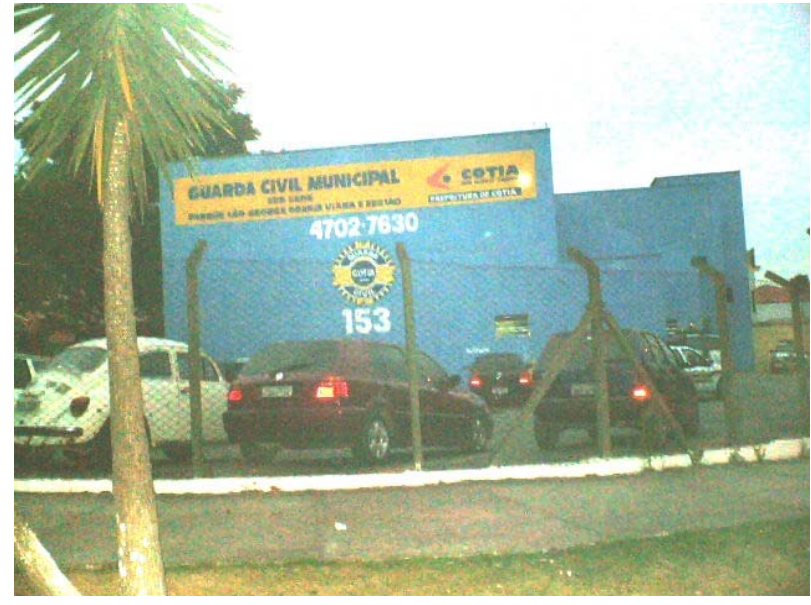

TRIVELATO, Ana C. (junho/2006)

As fotos acima mostram que é no Parque São George que estão localizados os principais pontos administrativos e de segurança da região granjeira, é lá (respectivamente Rua Direita e Av. Denner) que encontramos a subprefeitura e a guarda civil municipal. 
Mas as contradições ficam muito mais óbvias e "gritantes" quando colocamos as fotos das "três" Granjas Vianas perto uma da outra. Vejamos alguns exemplos:

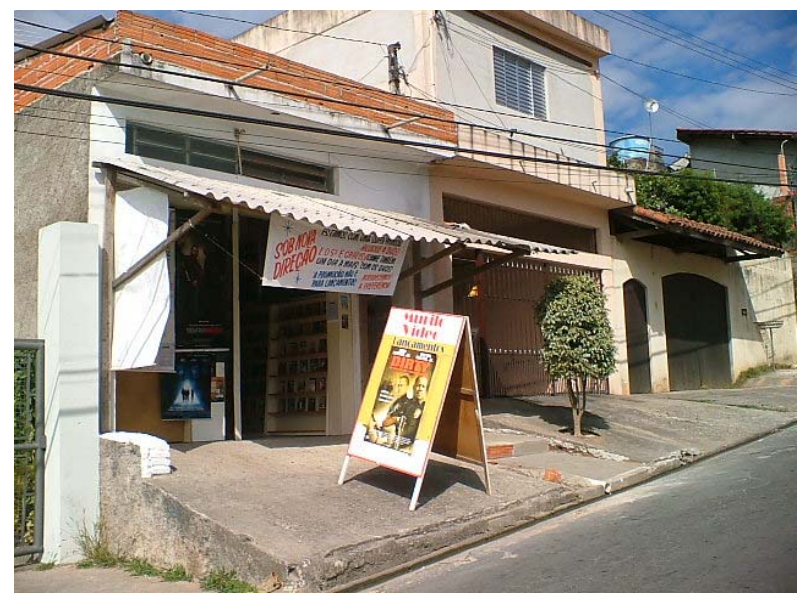

TRIVELATO, Ana C. (junho/2006)

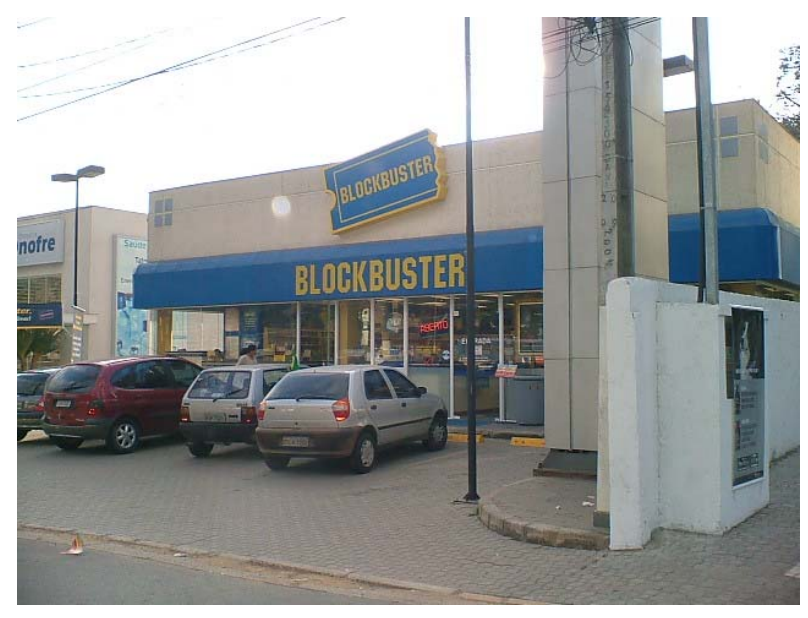

TRIVELATO, Karine Ap. (junho/2006)

As duas vídeo locadoras estão na Granja Viana, a primeira está na Rua dos Esquilos no Jardim da Glória e a segunda no Centro Comercial da rodovia Raposo Tavares.

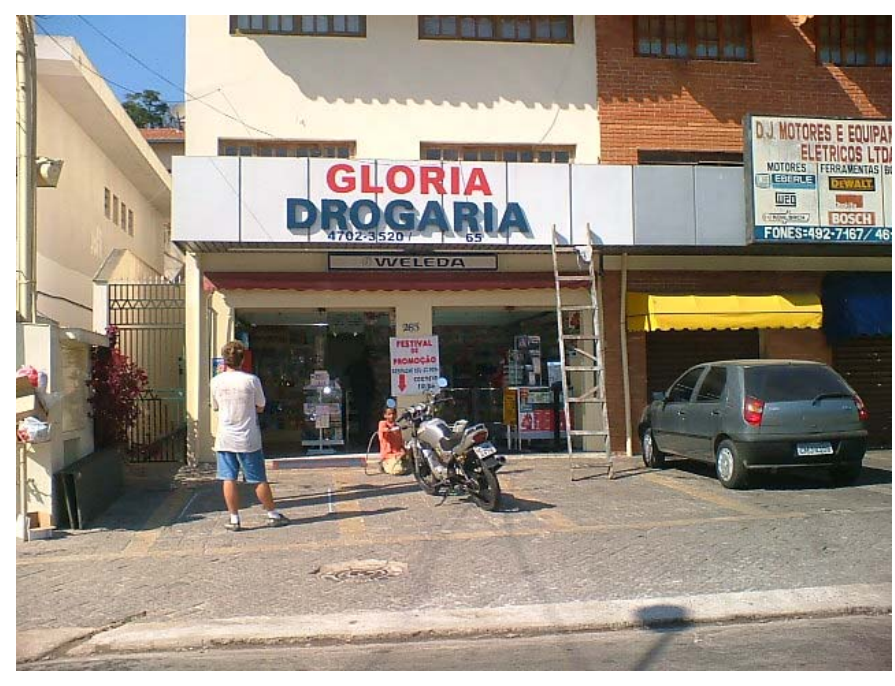

TRIVELATO, Karine Ap. (junho/2006)

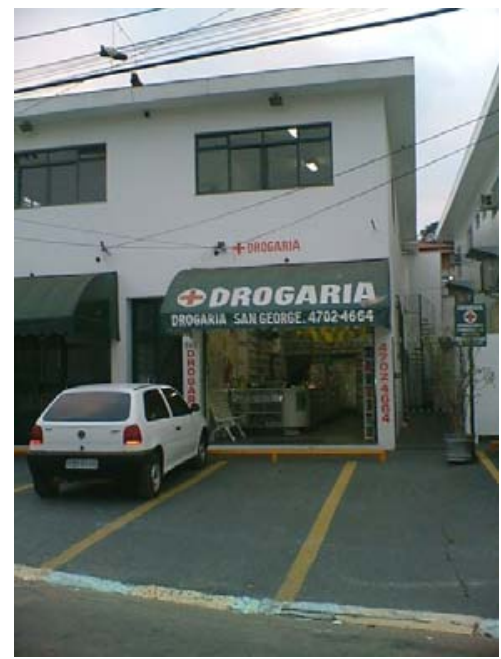

TRIVELATO, Ana C. (junho/2006) 


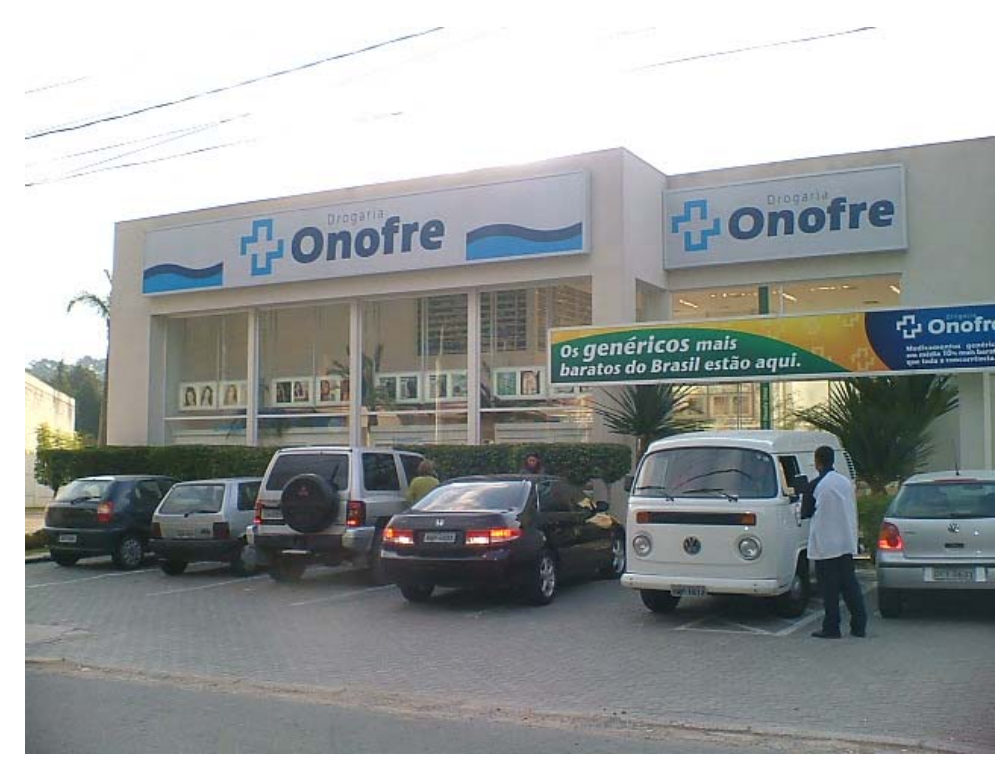

Trivelato, Karine Ap. (junho/2006)

Na foto acima, vemos três drogarias, sendo que todas estão na Granja Viana, a primeira está na Av. João Paulo Ablas, no Jardim da Glória, a segunda está na Av. Denner no Parque São George (para dar um certo "requinte" a drogaria tem seu nome escrito em inglês: Drogaria San George) e a drogaria da Granja Nobre, a "Drogaria Onofre", está no centro de consumo granjeiro (paralelo à rodovia Raposo Tavares).

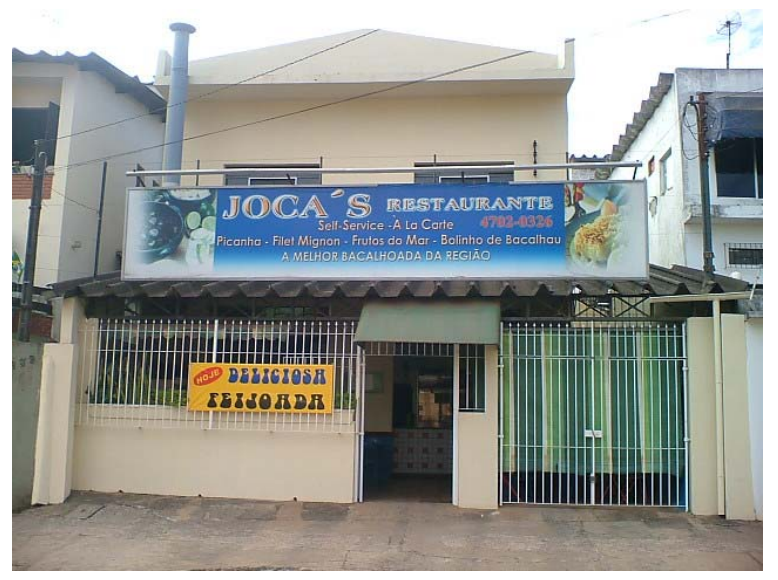

TRIVELATO, Ana C. (junho/2006)

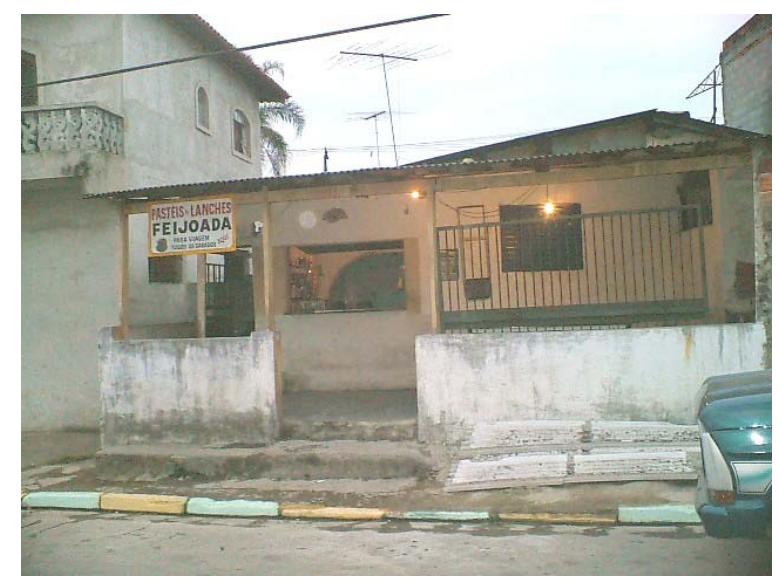

TRIVELATO, Ana C. (junho/2006)

As fotos acima mostram dois restaurantes que estão na Granja Viana, o primeiro está localizado à Av. João Paulo Ablas no Jardim da Glória e o segundo está localizado na Av. Denner no Parque São George, embora tenham fachadas diferentes, os dois são semelhantes quanto ao aproveitamento de uma construção residencial na constituição do comércio, nas duas situações há casas residenciais assim como outros comércios também. A distinção drástica que define o que é Granja Viana ou não está realmente 
na morfologia, basta compararmos essas duas realidades com a fotografia a seguir para percebermos o quanto auto-segregador a Granja Viana é.

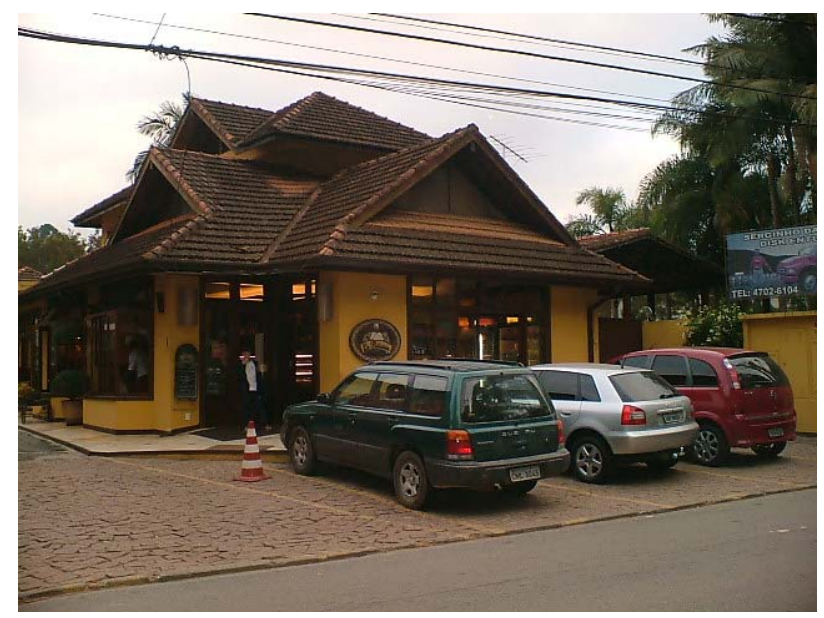

TRIVELATO, Ana C. (junho/2006)

A foto acima mostra um restaurante da Rua José Félix de Oliveira.

Para finalizarmos as comparações veremos, a seguir as fachadas de duas pizzarias, uma localizada na Granja Viana (Av. São Camilo) e outra na Granja Viana (Jd. da Glória).

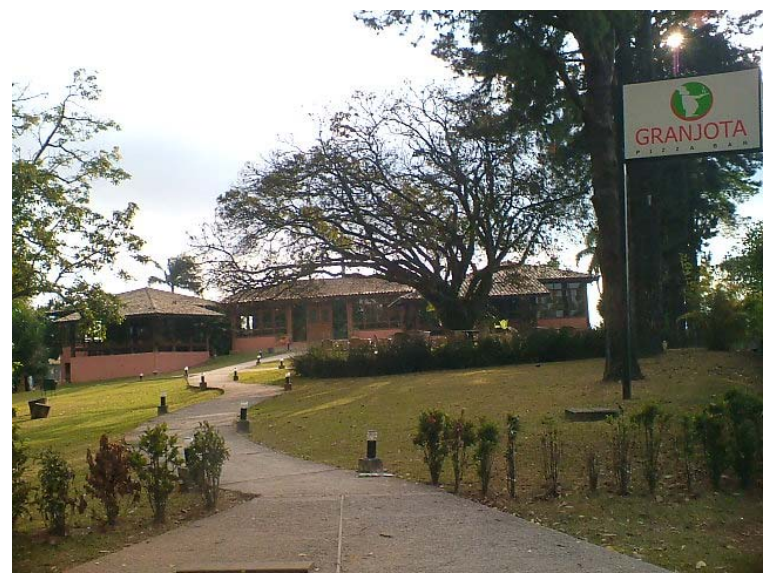

TRIVELATO, Ana C. (junho/2006)

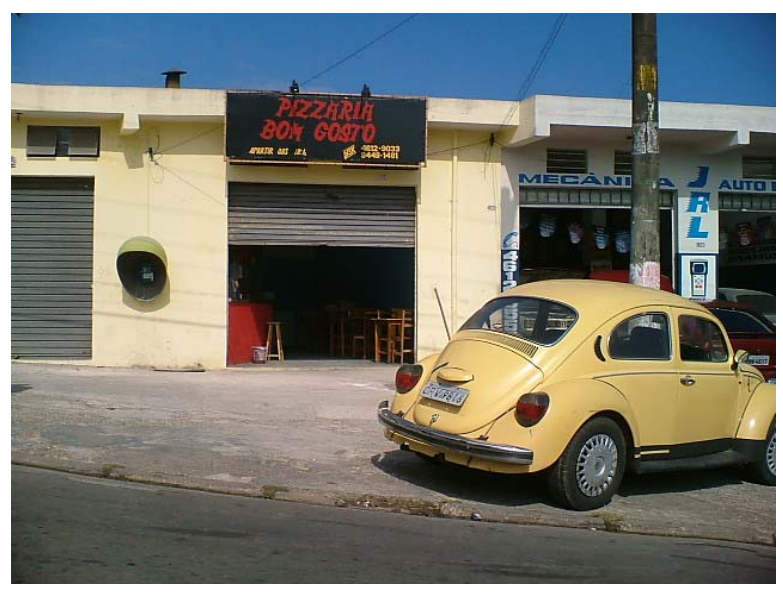

TRIVELATO, Ana C. (junho/2006)

É tão evidente esta "diferenciação" das Granjas, que se observarmos abaixo o mapa estilizado publicado no Guia Turístico Oficial de Cotia, veremos que as ruas da Granja Viana nobre aparecem, até porque a maior parte da "carteira" de custeio da publicação vieram dos comércios granjeiros (por meio do Rotary Club e dos contatos pessoais da então diretora do Departamento de Turismo da Secretaria de Educação, 
Cultura e Turismo, Sra. Cristina Maria Oka).O Jd. da Glória é resumido pela Av. João Paulo Ablas e a Rua dos Esquilos, e o Jd. São George tem uma posição mais desprivilegiada ainda: somente a Av. Denner aparece (nem a Rua Direita, onde está a Subprefeitura da Granja está contida, a subprefeitura está no final da Av. Denner, tamanho o reducionismo cartográfico).

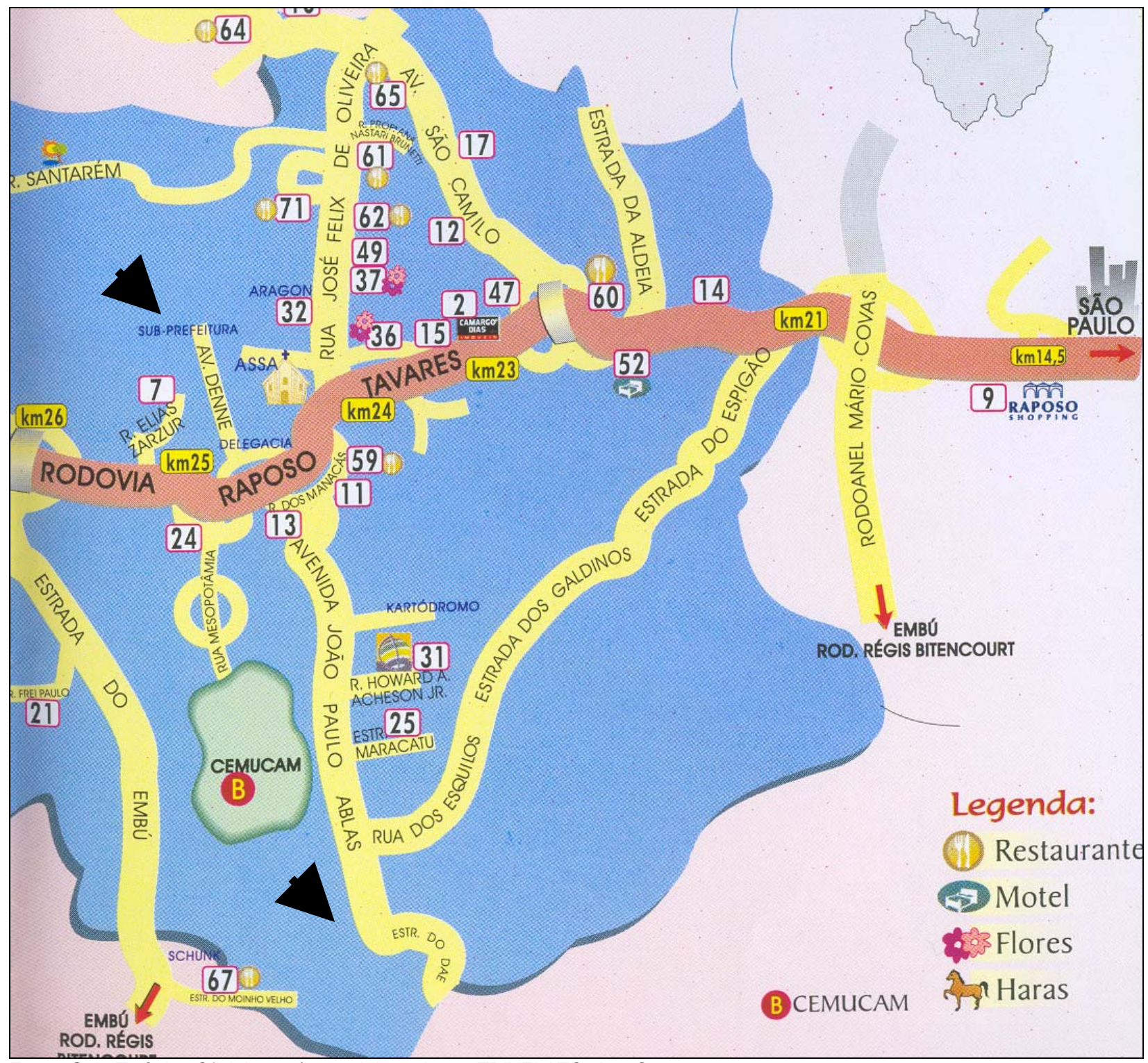

Fonte: Guia Turístico Oficial 2004/2005. Adaptado por TRIVELATO, Ana C.

Bem, se é certo que o território urbano compreende a formação social do trabalho que remonta à essa sociedade, a economia de troca se reproduz, a sociedade por meio do trabalho está hierarquizada, o mundo da mercadoria, da compra e venda, 
do valor de troca constantemente se impondo sobre o valor de uso, na Granja Viana nobre, não percebemos com tanta força, como nos outros ambientes, o "vivido", a vida em que o conhecimento dos vizinhos ainda é norma, aquela em que o dono zela pela propriedade (inclusive do outro vizinho), mas com um consenso de "boa vizinhança", onde haja uma "cooperação" da sociedade que fuja à racionalidade do mundo do trabalho.

Nas próprias tarefas do dia-a-dia percebemos a diferença entre as Granjas. Enquanto a vida social da Granja Viana nobre fica por conta de encontros marcados em restaurantes ou breves visitas "com hora marcada", no Jd. da Glória vimos uma rotina bem interessante, muito familiar, aliás, na periferia: temos a feira livre, pelo que pudemos notar, não é realizada por empregadas, mas pelas próprias "donas de casa", o que entra em contradição com a Granja Viana nobre, já que o caminhão da "frutaria" vai até os condomínios e são as empregadas que comumente fazem as compras (na porta de casa), ou então são essas mesmas empregadas (na maioria das vezes), que fazem as compras da semana no mercado granjeiro.

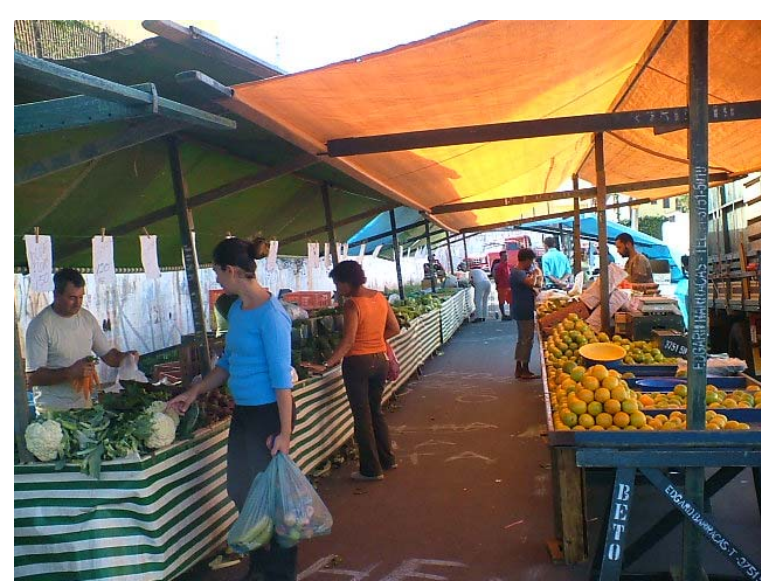

TRIVELATO, Karine Ap. (junho/2006)

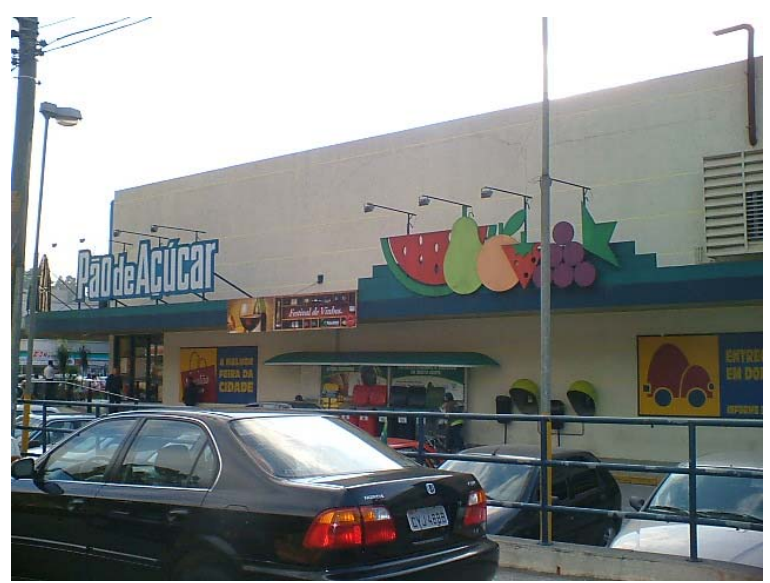

TRIVELATO, Karine Ap. (junho/2006)

As fotos acima retratam a feira livre na Rua Búfalo (Jd. da Glória) e Supermercado Pão de Açúcar (Boulevard da rodovia Raposo Tavares).

As pessoas do Jardim da Glória e do Parque São George foram muito mais amistosas e receptivas do que as pessoas da Granja Viana nobre, quando de nosso trabalho de campo. A diferença de comportamento das pessoas era muito grande. A precaução com a segurança na Granja nobre foi muito latente, os seguranças ficavam a 
postos e na maioria das vezes não "queriam saber de muita conversa não". De acordo com a Security (agência de segurança da maioria do comércio granjeiro), essa "hostilidade" faz parte da formação deles (seguranças).

Reação muito diferente da maioria das pessoas abordadas por nós no Jardim da Glória e do Parque São George. Neste último, especificamente na drogaria (San George) a vendedora se interessou muito pela idéia de fotografar a Granja e alguns rapazes que estavam num outro comércio local também da Avenida Denner, ficaram tão empolgados com a possibilidade de registro fotográfico, que depois de um pouco de conversa pegaram uma bandeirola "verde e amarela" (devemos lembrar aqui, que a entrevista foi feita em junho, época da copa (2006) e o Brasil disputava a participação das oitavas) e ficou agitando-a na frente do seu comércio enquanto a fotografia estava sendo feita.

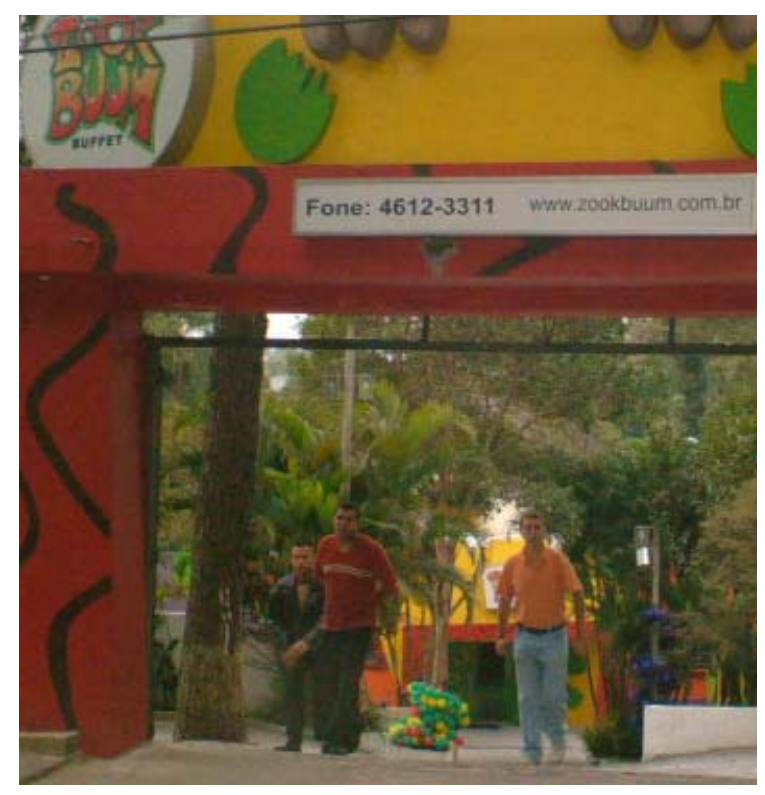

TRIVELATO, Ana C. (junho/2206)

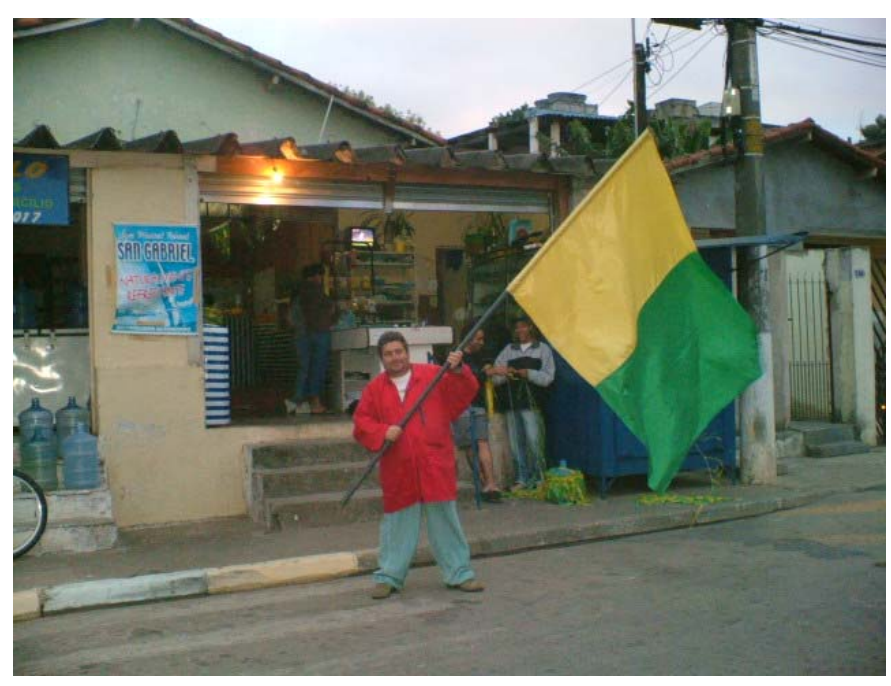

TRIVELATO, Ana C. (junho?2006)

As fotos acima mostram comportamentos diferenciados entre a Granja Viana nobre e a periférica respectivamente.

É como se o uso do espaço se desse pelo direito ao tempo, de conversar, de posar, de rir, é o uso do espaço e a troca que geram duas forças necessárias para definir as relações sociais verificadas no espaço mesmo encoberta pelas ideologias, como por exemplo, uma prestadora de serviços especializada em manutenção de 
refrigeração no Parque São George, cuja fachada mostra a precariedade de espaço e "arquitetura" e na sua "placa de identificação comercial" não estava escrito "Refrigeração São George", mas "Refrigeração Granja Viana". Estamos tão acostumados a considerar as duas regiões granjeiras "menos onipotentes" como não sendo Granja Viana e sim Jardim da Glória e Parque São George, e ao mesmo tempo por uma questão de ideologia, o nome "Granja Viana" está tão impregnado de "luxuosidade" que, ao vermos a placa e a fachada juntas temos uma sensação de estranhamento causado por uma contradição em dois aspectos:

O primeiro está torno do fato de que a Granja Viana está tão vinculada ao belo, requintado, paradisíaco que não caberia ter uma prestadora para manutenção de refrigeradores, e o segundo é mais estranho ainda, pois a informação contida na placa está certa, pois o Parque São George é também Granja Viana.
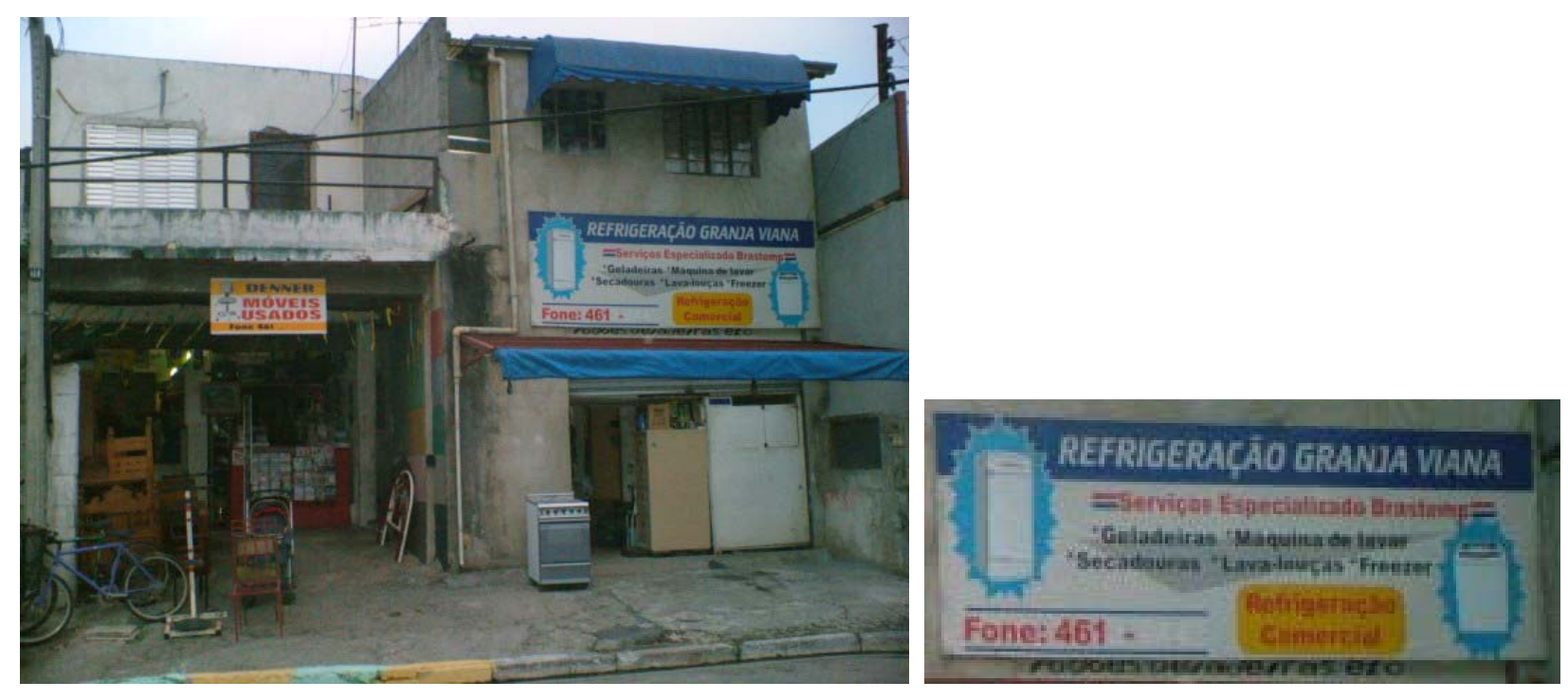

TRIVELATO, Ana C. (junho /2006)

A foto acima mostra a fachada de dois prestadores de serviços do Parque São George, nos chamou a atenção a "Refrigeração Granja Viana", pouco usual no comércio local.

Embora a Granja Viana esteja fragmentada, tudo converge para ela mesma, as pessoas mesmo estando em "limites rígidos" de acordo com sua classe social, construíram uma identidade muito própria de forma que todos que moram nesta região sejam "granjeiros". Talvez seja esta a única forma de contemplar a riqueza de poucos 
ou este é o nascimento do conhecimento e lugar de reprodução de todas as relações sociais que de alguma forma dá vida àquele espaço de excelência e pobreza.

Esse espaço abstrato reúne o espetáculo e a violência, a eficácia do espírito analítico na e pela dispersão, separação, segregação. A reunião de forma heteronômica é autoritária, realizando a separação. (DAMIANI, 2001:53)

A Granja Viana nos parece ser um espaço abstrato, onde tudo e nada acontecem ao mesmo tempo, a reunião de todos em torno de uma identidade forte como a granjeira, do orgulho de pertencer a um grupo tão eleito e ao mesmo tempo permitir a separação, onde as classes sociais e as diferenças estabelecidas ao "consumir" o espaço promovem um asseveramento das relações, as pessoas encontram os mesmos, não há o diferente, pois ele está bem distante de seus olhos.

Todos estão dentro e ao mesmo tempo fora da Granja Viana. É a Granja dos tradicionais, dos novatos, dos ricos, dos pobres, da ostentação, da simplicidade, do consumo, da contemplação, de todos e de um só. A Granja Viana é tudo e ao mesmo tempo nada, ela é também uma construção mercadológica, onde as relações são forjadas, onde o "vivido" tente a ser manipulado pelo capital que precisa acima de qualquer coisa garantir a sua reprodução.

Vejamos o caso do Sr. Corino. Ele tem 56 anos e mora na Granja Viana desde 1.974. Veio de São Paulo e trabalhou na construção civil, “... ajudei a construir casas de muita gente importante", ele diz com muito orgulho ao apresentar seu currículo. Ele também já foi jardineiro e hoje (com um cheiro muito forte de bebida alcoólica) é um morador de rua (Avenida Denner - Parque São George), e de vez em quando ele vai para um bairro distante dali para se abrigar, descansar e tomar banho. Ele se diz "... granjeiro porque moro na Granja Viana...", mas não entende porque ele não tem nada... 


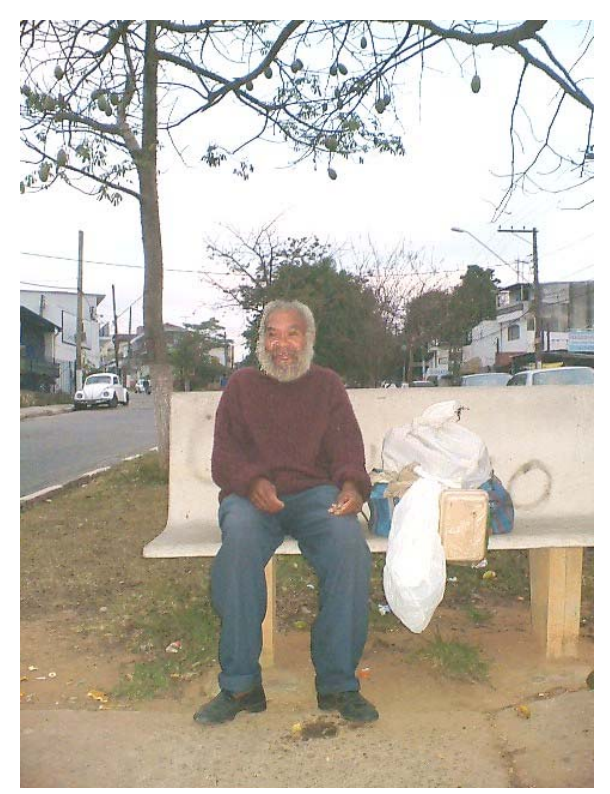

TRIVELATO, Ana C. (junho/2006)

Foto de um morador de rua granjeiro.

Os fragmentos integrados de uma região como a Granja Viana estão permeados de representações que mediam os comportamentos sociais, ora de pertença, ora de auto-segregação; os conteúdos social e cultural vão dando significado para um espaço criado também pelo mercado, onde as formas vão recebendo seu conteúdo, as pessoas não podem "consumir" os espaços granjeiros de forma igual, os símbolos e os signos são reconhecidos por todos, a leitura é realizada, e a divisão criada e estabelecida.

Vimos até agora que a região granjeira está dividida de várias formas, uma delas é por meio das classes sociais, existe uma Granja nobre e uma Granja empobrecida, perceber as diferenças no parcelamento e uso do solo, das estruturas prediais ou ainda no aparato comercial e prestadores de serviços que diferenciam essas Granjas nos parecem ser mais simples do que captar as relações existentes entre as pessoas destas diferentes Granjas.

A relação estabelecida entre os mesmos possui conflitos intrínsecos como já vimos, principalmente na Granja nobre, contudo, saber como é a relação entre os diferentes neste espaço, que é a Granja de todos, torna-se uma questão importante, pois, a nosso ver, a Granja Viana nobre e a periférica coexistem, juntas: não há uma se 
não existir a outra. As muitas funções da Granja Viana nobre tem seu contingente na periferia granjeira, aí está a relação entre as duas Granjas. De acordo com SEABRA (2004:199)

A solução da separação é e continua sendo problemática, pois não há como evitar que o pobre, do que foi planejada a separação, esteja dentro de casa, que prepare a comida que vai ser servida, arrume as camas, cuide das roupas e, não raras vezes, fique com as crianças o dia todo...

A Granja Viana constitui um grande mercado de trabalho, pois nela há residenciais de médio e alto padrão, há comércios e prestadores de serviços e muitas indústrias, enquanto a maior parte dos moradores da Granja nobre mantém seu trabalho e vida social na grande metrópole, a maioria dos moradores da Granja periférica tem seu trabalho bem ali, na Granja Viana mesmo.

Segundo o Ciesp $^{37}$ (Rua do Amor Perfeito - Estrada do Embú/Granja Viana), é expressivo o número de granjeiros trabalhando em suas indústrias. Ainda hoje existe uma quantidade muito grande de indústrias de todos os portes (inclusive a de trabalho familiar e, portanto, muito pequena ainda) operando na Granja Viana como um todo (lado direito ou esquerdo, nas proximidades da rodovia Raposo Tavares, sendo possível observá-los passando pela rodovia ou "afastados" precisando entrar nas ruas vicinais para acessá-los), as "linhas de produção e montagem" absorvem parte da mãode-obra granjeira (periférica), sendo que as atividades de comando destas mesmas indústrias geralmente ficam por conta de executivos paulistanos.

Conversando com os comerciantes (Avenida José Giorgi) constatamos a seguinte realidade: nos comércios granjeiros a preferência é dada às pessoas que vêm do Jardim da Glória e da região central de Cotia - do Centro de Cotia para ser mais preciso, pois quanto mais distante da Granja, mais caro fica a "condução" dos empregados, custo este que geralmente é pago pelo empregador. Logo o fator distância é relevante para a contratação do funcionário. No caso dos comércios da Granja Viana periférica, no Jardim da Glória (e imediações) ou ainda no Parque São George, sabemos que a maior parte dos trabalhadores são da própria localidade. 
Para o trabalho doméstico da Granja nobre (nas casas e mansões), tivemos uma grande surpresa, pois a preferência tem sido dada aos trabalhadores vindos de Carapicuíba (cidade vizinha de Cotia que faz limite no extremo direito com a Granja e tem acesso pela Av. São Camilo). Existe um ônibus que faz o seguinte trajeto: Cotia Carapicuíba - Alphaville, ficando a volta da seguinte forma: Alphaville - Carapicuíba Cotia. Nesse sentido, Carapicuíba "abastece" o mercado de trabalho doméstico de Alphaville e Cotia (Granja Viana nobre): os pontos do ônibus vermelho (assim chamados os ônibus que vêm de Carapicuíba) são estrategicamente localizados nas proximidades dos "grandes" complexos de bolsões e condomínios residenciais granjeiros (como no Km 24, 26,5 e 28,5 da rodovia Raposo Tavares). A preferência na contratação dos chamados serviçais é dada geralmente para as pessoas que vêm de Carapicuíba por causa do valor da mão-de-obra, "cartas de referência" dos mesmos além do fácil acesso pelos meios de transporte público como verificamos..

Segundo esses dados, existe uma relação entre a Granja nobre e a Granja periférica, imperando nessas relações a questão do trabalho: as ordens e o cumprimento delas parecem ser a única "ponte" entre estes dois universos tão diferentes. As várias faces da Granja Viana constituem o inteiro, ainda que nem todos reconheçam a existência do outro.

O não reconhecimento da existência de diferentes na Granja pode ser percebido por meio das propagandas do mercado imobiliário. Os outdoors e os banners vão anunciando os belos espaços da Granja pela rodovia. Há um "descomprometimento" dos granjeiros da área nobre com relação a área periférica. Voltaremos a nos utilizar do croquis de localização dos empreendimento residenciais granjeiros já observado no Capítulo I, com a intenção de evidenciar a "ausência" do reconhecimento do Jardim da Glória como parte da Granja Viana, já que na Av. João Paulo Ablas existem vários residenciais e não constam na ilustração que se segue.

${ }^{37}$ Centro das Indústrias do Estado de São Paulo. 


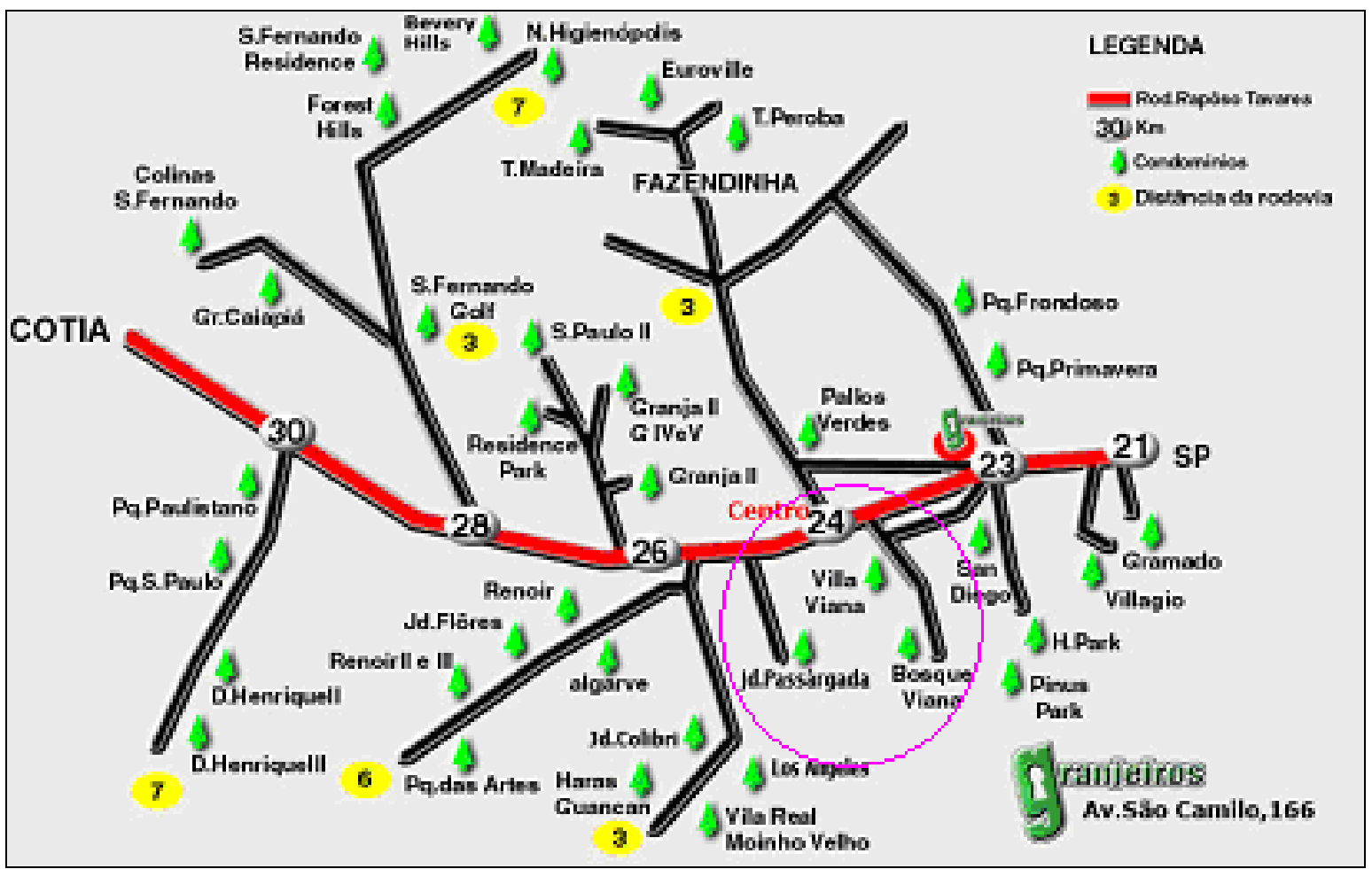

Fonte: www.granjeiros.com.br (junho/2006)

Ao longo da história da Granja temos relatos de empreendimentos de construções formais que poderiam atrair pessoas de baixa renda para o consumo de determinadas atividades e espaços na área Granjeira nobre: há alguns anos atrás um "prédio japonês" seria construído na Granja nobre para atividades comerciais, mas, segundo os granjeiros mais "ativistas", esse prédio abriria precedentes para a construção de outros (inclusive de moradias) e então a Granja nobre poderia ser popularizada por meio de construções verticalizadas; os granjeiros não deixaram isso acontecer e, em função disso, todo o município cotiano se viu privado da possibilidade de verticalização do espaço. 


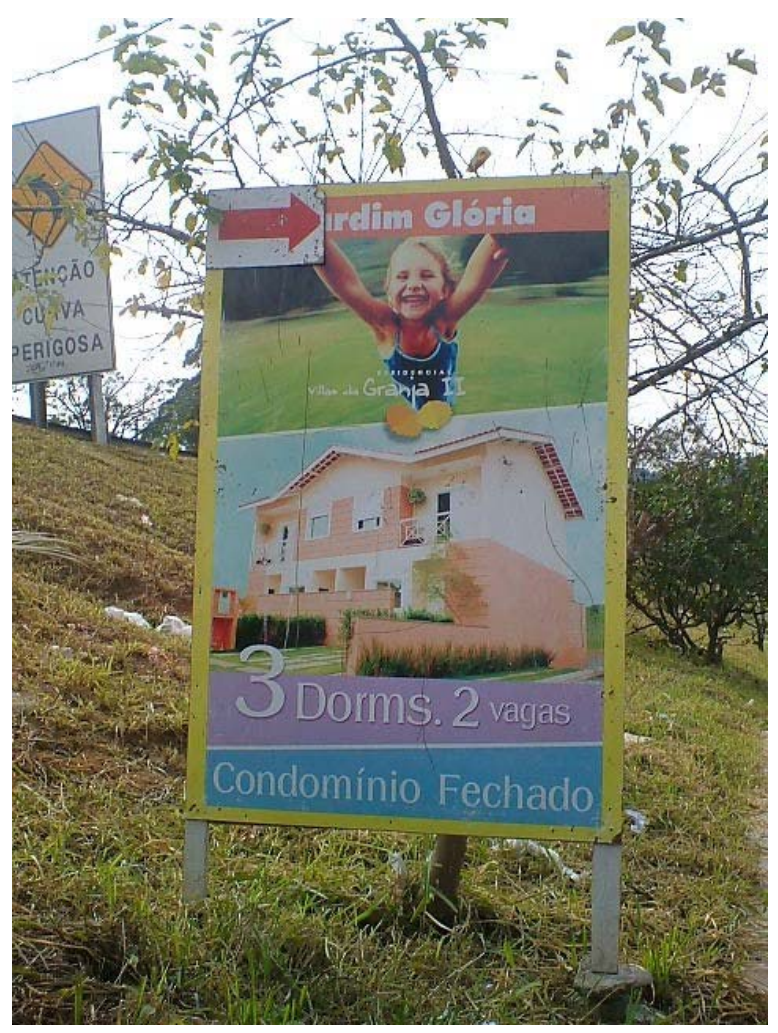

TRIVELATO, Ana C. (junho/2006)

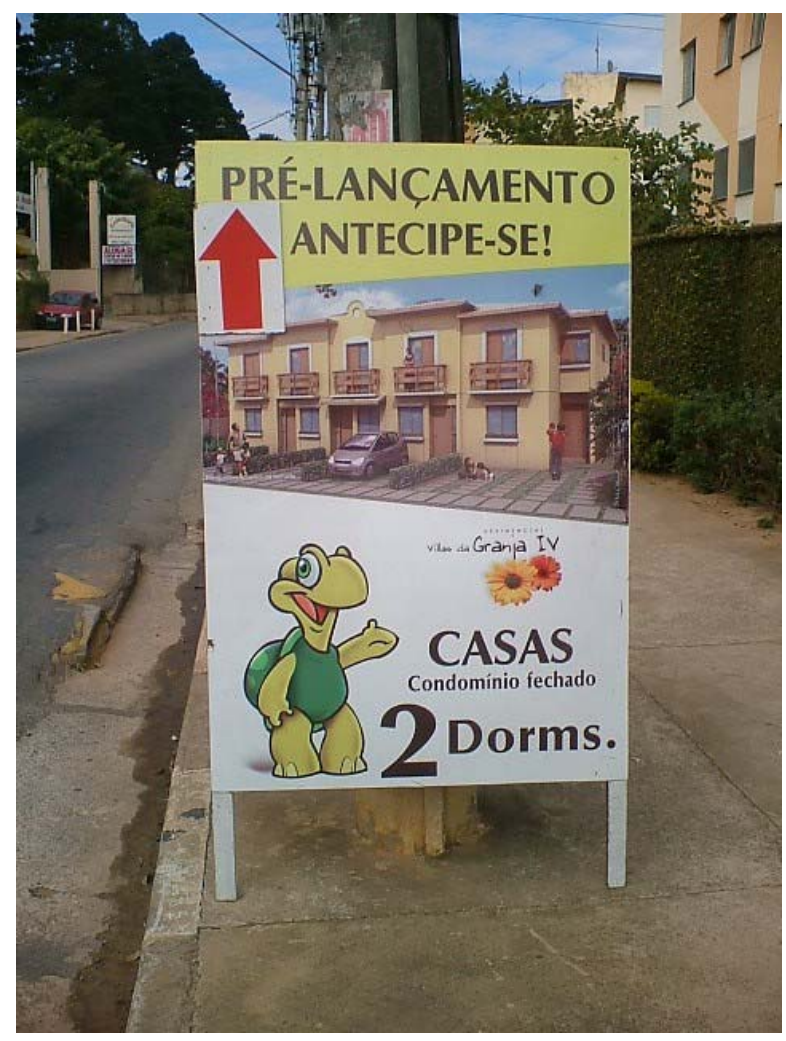

TRIVELATO, Ana C. (junho/2006)

As fotos acima mostram banners colocados próximos à rodovia Raposo Tavares, para venda de condomínios (empreendimentos diferentes entre si).

Essa problemática por nós apontada parece contemplar a idéia de que "... A auto-segregação nos condomínios fechados resolve parcamente as questões para aqueles que integram esse movimento de fragmentação acelerado do urbano como quadro de vida..." (SEABRA, 2004:203). A Granja Viana periférica, pelo exemplo do Jardim da Glória, está sendo dividida em pedacinhos e vendida por um valor bem acessível à população de baixa renda. Os moradores locais têm percebido essa tendência como nos mostra a fala do Sr. José Carlos Pereira, um morador antigo do Jardim da Glória (Av. João Paulo Ablas) e comerciante na região. Ele afirma que uma grande área (antiga olaria) que fica ao lado do seu trailler será transformada dependendo apenas da decisão de seu proprietário: “... o dono ainda não se decidiu se vai fazer galpão para indústria ou condomínio de casas pequenas, como está acontecendo por aí...". 


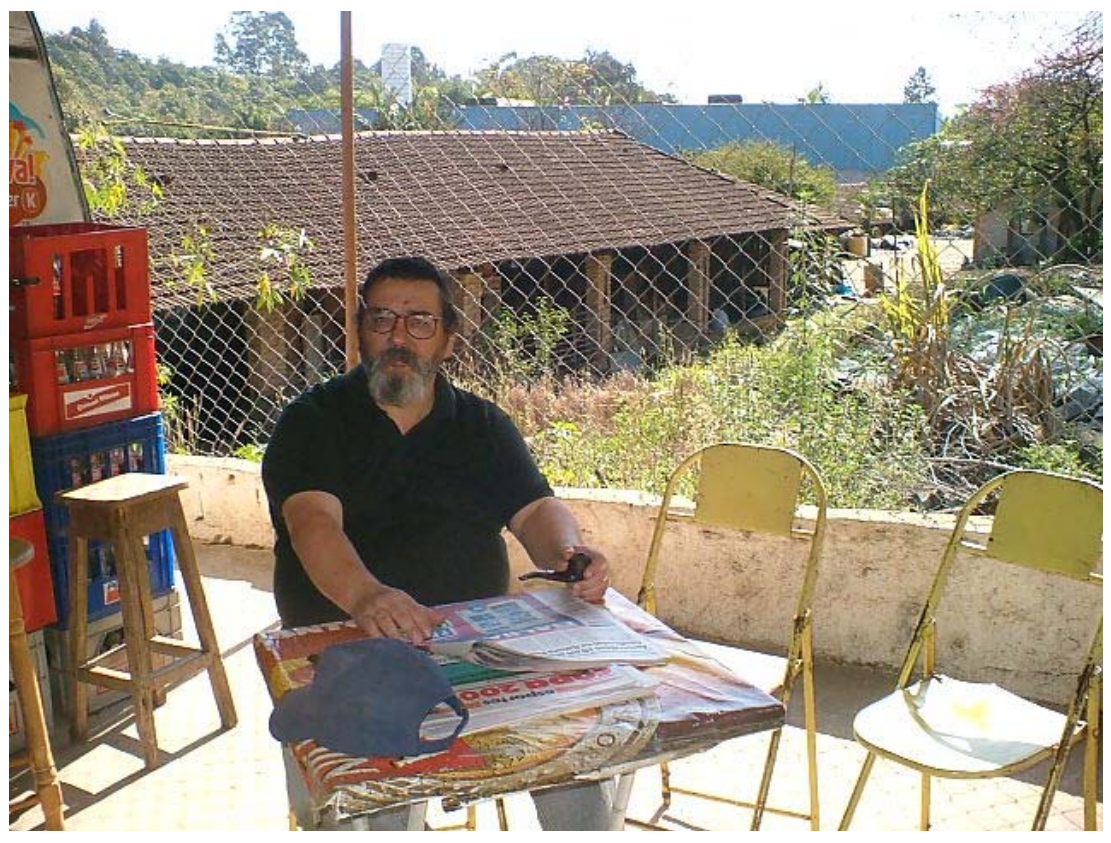

TRIVELATO, Ana C. (junho/2006)

Na foto acima vemos ao fundo uma antiga olaria, o espaço será reconstruído e terá outra finalidade.

Existe uma "lógica" na (re) produção espacial granjeira que expressa práticas sociais. A hierarquização espacial é um dos reflexos da nossa condição. Fazemos parte de uma sociedade que é capitalista, onde tudo se tornou mercadoria: os espaços, as formas e as relações, tudo parece ter ganhado um valor de uso e de troca diferenciado. Tudo está dividido em classes e os espaços são uma amostra desse processo. A região granjeira não é vista como um todo, mas como partes aparentemente independentes, com funções específicas e predeterminadas. Até a chamada "identidade granjeira" tem que ser relativizada: "Todos da região são granjeiros, mas uns são mais granjeiros que outros"38.

A maioria dos moradores do Parque São George ou Jardim da Glória e "região" estão acostumados com o entendimento de que a Granja Viana é um espaço de "status" criado pelo mercado imobiliário, a ponto de se auto-denominarem "granjeiros" ou dizerem que são da "Granja Viana", pensando valer-se do crédito alcançado pela Granja nobre, até porque, internamente eles serão sempre reconhecidos como do

\footnotetext{
${ }^{38}$ Alusão à ORVEL, George em "Revolução dos Bichos", numa crítica do socialismo (decadente) às classes sociais do capitalismo, diz numa das passagens sobre as ovelhas que fazem uma leitura "enviesada" das novas leis do Solar onde: "Todos são iguais, mas uns são mais iguais que outros."
} 
Jardim da Glória ou Parque São George (evidenciando que são pessoas de bairros populares), não pertencem à Granja Viana (nobre).

Entender os conflitos e as diferenças existentes na região da Granja Viana é entender a própria lógica da produção espacial para garantir a reprodução do capital. Há uma fragmentação, uma divisão interna na Granja Viana que revela a lógica de nossa sociedade e que se insere no comportamento de seus moradores. As pessoas, aparentemente, não compartilham de uma mesma realidade, existindo várias realidades num único espaço: a Granja Viana iluminada, anunciada e vendida, obscurece e oculta àquilo que lhe é diferente.

As relações são forjadas e o encontro entre os vários fragmentos da Granja em geral se realiza entre os iguais, cada igual com o seu grupo correspondente. Os diferentes também se encontram, mas justamente naquilo que Ihes contrapõem, no poder de consumo, os "empregados e patrões", os "clientes e serviçais" se percebem por alguns instantes, mas de forma tão superficial que parece não dar tempo para que a dimensão do "vivido", no sentido proposto por Lefebvre, aflore de modo mais intenso. 


\section{Considerações Finais}

Na geografia, entender e explicar a sociedade por meio do espaço é uma grande meta. A complexidade que o envolve é dada pelas relações sociais que se fazem parte e nele se dão. As ideologias e contradições permeiam este contexto de forma a envolver o espaço e a sociedade num sentido de mão dupla, ou seja, a sociedade produz seu espaço enquanto este interfere na relação do próprio homem enquanto sociedade.

Entender a cidade e o urbano não é tarefa fácil. As obras e teorias que tentam explicar a constituição desta verdadeira "explosão" de relações (social, espacial, afetiva, mercantil, simbólica e ideológica) conduzem a uma reflexão de múltiplos entendimentos. Entender a realidade a partir do que lemos na realidade cotidiana é, para o geógrafo, quase sempre uma ação inevitável, e é neste momento que percebemos o quão difícil é apreender este espaço num único olhar.

A sociedade, inserida em um tempo histórico, com sua produção, suas formas de propriedade e ação do capital, tende hoje a ser urbana e na vida urbana um espaço privilegia com maior intensidade essa vida: a cidade. Esta ao mesmo tempo em que serve de condição para as realizações humanas é produto das mesmas. Nas cidades se reúnem diferentes escalas da vida e, assim, movimentos globais e locais coexistem, sendo muitas vezes percebidos nos fragmentos que fazem parte do todo e sem os quais não existiria. Nelas há a possibilidades dos encontros e desencontros, onde a confusão e a ordem não são antônimos nas cidades, a contradição é uma característica.

Depois de alguns anos de um olhar mais "aguçado" quanto ao "pedaço de realidade" que procuramos entender junto ao nosso parco conhecimento, ficamos com a sensação de que o que compreendemos daquilo que perseguimos por tanto tempo não ainda não consegue explicar a cidade, ou um fragmento que seja, mas aponta para alguns processos que dela fazem parte.

Os conceitos aplicados por LEFEBVRE em palavras que parecem traduzir o diaa-dia, como o vivido, o cotidiano, as possibilidades, a festa e o urbano parecem estar 'naturalmente' contidos nas relações sócio-espaciais. Para nós, seria impossível pensar 
essas relações sem essa produção, mas quando focamos nossa lente na realidade observamos que essas mesmas relações parecem ter sido capturadas a ponto de não conseguirem, na maior parte das vezes, se apresentarem enquanto uma dimensão que poderia por em questão a forma de reprodução do capital em nossa sociedade. Visto por este ângulo, o espaço, assim como a sociedade, passa por um processo de "reificação", e a idéia de que "o valor de troca sobrepõe ao valor de uso" passa a fazer sentido então.

Nos debates acadêmicos aparece a discussão a respeito da "possibilidade" das "superações" em relação às armadilhas da "lógica capitalista" nas relações sociais e desta com o espaço no cotidiano, uma forma de superação a todo instante, um desdobramento do mundo da mercadoria para o mundo da criação, mas durante o trabalho percebíamos que os momentos de continuidades e descontinuidades gerados pelos conflitos, que poderiam ser a "possibilidade" de "superação", apareciam de maneira tão desbotada que não conseguimos nos responder até agora se poderiam ser passos para a "superação".

O tempo-espaço indissociáveis talvez seja a chave para essas "superações". As relações por nós observadas na realidade são quase sempre estabelecidas de forma muito rápida, e os encontros - não com os mesmos, mas com o diferente - são tão difíceis de acontecer e, quando acontecem são tão rápidos, na maioria das vezes mediadas por um "pedido", uma "ordem", um "sinal", que a realização parece ficar definitivamente no campo mercadológico, onde tudo é descartável, rápido, impessoal e tem um único valor, o de troca.

É sob esta ótica que reconhecemos a Granja Viana, um fragmento espacial da grande metrópole paulistana, que pode dar dimensões de uma totalidade. Esse espaço é apresentado pela mídia, a nosso ver, como um lugar "espetacularizado", parcelado e vendido como raridade. É o espaço enquanto produto que é consumido à medida que a privatização dos lugares e a auto-segregação vai acontecendo.

A Granja Viana, ainda que formalmente seja parte do município de Cotia, só pode ser entendida pelas relações com a cidade de São Paulo. É por essa relação que ao mesmo tempo a reafirma como a lugar da vida e, contraditoriamente a nega, que 
espaços, como o da Granja Nobre, são criados num movimento que homogeneíza determinados lugares por suas formas e funções. Deste modo, áreas como essa da Granja, vão sendo organizadas pelos urbanistas, engenheiros e paisagistas, e assim o espaço de "primazia" residencial vai se posicionando enquanto mercadoria exposta numa vitrine, a dos outdoors.

O status de consumir a Granja Viana parece muitas vezes fazer adormecer a vida cotidiana, os códigos de acesso e os signos estabelecidos por meio das construções erigidas no espaço fazem com que as relações sócio-espaciais fiquem cada vez mais superficializadas, os diferentes grupos de moradores e freqüentadores granjeiros vão se estabelecendo e, junto com a determinação dos grupos, alguns lugares são eleitos como os a freqüentar.

A tentativa de formar uma Granja orgânica, onde tudo vai se ajustando e "funcionando" perfeitamente, cada qual no seu espaço e com o seu grupo, acaba sendo somente uma "estratégia de marketing", pois essas relações escapam do controle e então surgem os conflitos por meio das contradições - o tradicional e o moderno ou o velho e o novo - o espaço de um e de outro fica estabelecido por limites, ora plásticos, ora rígidos, trata-se do próprio movimento de transformação.

Mas esse movimento de transformação tem certamente uma força inicial: a necessidade de reprodução do capital. Os conflitos entre o tradicional e o moderno, surgem do impulso de resguardar a identidade local (espaço e população), numa tentativa de salvaguardar investimentos associado a "exigência" do mercado imobiliário em modernizar o espaço, já então priorizado enquanto uma mercadoria, em nome de sua valorização, ainda que o discurso seja a melhoria de vida das pessoas nesses espaços.

O valor do uso do espaço vai ficando subjugado ao valor de troca. Os espaços criados para o consumo e que promovem os "encontros", vão ficando cada vez mais comuns na área granjeira. A lógica da produção de espaços presente em São Paulo vai sendo reproduzida na Granja Viana também, ou seja, trata-se do mesmo processo.

Fragmentos espaciais refletem uma composição social. A Granja Viana da mídia e do marketing, àquela considerada como área nobre e voltada para a população mais 
abastada, tem sua área periférica também. Entender o espaço é sem dúvida nenhuma entender a própria sociedade, e assim, nos lugares da Granja vez ou outra os diferentes se encontram, gerando o inesperado, a partir do contato, ainda que momentâneo, entre realidades muito diferentes: de um lado aquela oferecida pela grife granjeira de sucesso, beleza e abundância e de outro a da escassez.

Todos são granjeiros. Enquanto uma parte da população da região cria uma identidade pelo consumo do lugar autodenominada de granjeira, uma outra parte "luta" tentando se convencer de que é também granjeiro. Nesse último caso, o "ser granjeiro" está relacionado com o fazer parte de um lugar e de que, pertencendo a esse, mesmo que só formalmente, garante uma condição diferenciada no município cotiano. As pessoas que aí vivem podem falar com "orgulho" aos outros munícipes que "moram na Granja". Ainda que todos "morem" na Granja é pelo poder de consumo que não só se diferenciam, mas que também usam o espaço. Ficou claro, em nosso estudo, que na região os "opostos se repelem", as pessoas não compartilham socialmente os mesmos espaços, somente se houver muito clara a hierarquização de poder entre os mesmos é que o encontro furtivo (entre patrões e empregados, por exemplo) pode acontecer.

Mas foi no poder de valorização de outros espaços que a região granjeira possui, que pudemos notar a força de (re) produção espacial deste espaço nobre. A surpresa foi perceber que a Granja Viana, voltada para uma elite, é capaz de mudar a tendência de lugares que nem pertencem a essa região iluminada. Temos como um claro exemplo desse processo parte do bairro do Portão, que é considerado região central em Cotia e que estabelece uma área de contato com a região granjeira, que foi num curto prazo de tempo "reconfigurado" para que os granjeiros de maior poder aquisitivo pudessem consumir.

Deste modo, pelas relações estabelecidas se (re) configuram os lugares que, a partir de suas formas que implicam em entendimentos sobre o lugar, "impedem" o "consumo" comum de determinados lugares que foram produzidos tendo como público alvo os "granjeiros nobres". Isso reforça a idéia de que o espaço pode refletir as divisões sociais e ao mesmo tempo as produz. Os conflitos por nós aqui apontados, ao 
longo do trabalho, podem gerar desdobramentos, pois é na possibilidade da descontinuidade na continuidade que talvez se geram novos espaços. 


\section{Bibliografia}

ARANTES, Otília. Urbanismo em fim de linha. São Paulo: Edusp, 1998.

BERMAN, Marshall. Tudo que é sólido desmancha no ar: a aventura da modernidade. Tradução: Carlos Felipe Moisés e Ana Maria L. Ioriatti. São Paulo: Companhia das Letras, 1986.

BOURDIEU, Pierre. Efeitos do lugar. In: A miséria do mundo, $3^{\circ}$ ed. Petrópolis: Vozes, 1999, pp. 159-166.

CARLOS, Ana Fani. "A (Re) Produção do Espaço Urbano. O caso de Cotia". Universidade de São Paulo. Faculdade de Filosofia, Letras e Ciências Humanas. Departamento de Geografia, 1.986.

CARLOS, Ana Fani Alessandri. Espaço-tempo na metrópole: a fragmentação da vida cotidiana. São Paulo: Contexto, 2001.

CARLOS, Ana F. A. "Novas" contradições do espaço. In: DAMIANI, Amélia L., CARLOS, Ana Fani A. e SEABRA, Odette C.de L. O espaço no fim do século: a nova raridade. $2^{\mathrm{a}}$ ed. São Paulo: Contexto,2001.

CARLOS, Ana Fani Alessandri. A cidade. $7^{\circ}$ ed. São Paulo: Contexto, 2003. (Repensando a Geografia).

CARLOS, Ana Fani Alessandri. Uma leitura sobre a cidade. In: Cidades: Revista Científica/Grupo de Estudos. Presidente Prudente: Grupo de Estudos Urbanos, 2004.

COTIA. Lei Complementar n. 001 de 11 de setembro de 1991.

DAMIANI, Amélia L. As contradições do espaço: da lógica (formal) à (lógica) dialética, a propósito do espaço. In: DAMIANI, Amélia L., CARLOS, Ana Fani A. e SEABRA, Odette C.de L. O espaço no fim do século: a nova raridade. $2^{\mathrm{a}}$ ed. São Paulo: Contexto,2001.

DAVIS, Mike. Cidade de Quartzo: Escavando o futuro em Los Angeles. Tradução: Renato Aguiar. São Paulo: Scritta Editorial, 1993.

DURKHEIM, Émile. "Da divisão do trabalho social; As regras do método sociológico; O suicídio; As formas elementares da vida religiosa". Tradução de Moura, Carlos A. R. (et.al.). São Paulo: Abril Cultural, 1.978 (Coleção Os pensadores);

GARCÍA - TORNEL, Francisco Calvo. "Sociedades y territorios en riesgo". Barcelona: Ediciones del Serbal, 2.001. 
LEFEBVRE, Henri. A revolução urbana. Tradução de Sérgio Martins. Belo Horizonte: Ed. UFMG, 1999.

LEFEBVRE, Henri. O direito à cidade. São Paulo: Centauro, 2001.

LEFF, Enrique. Saber ambiental. Petrópolis: Vozes, 2001.

MARICATO, Ermínia. Brasil, cidades: alternativas para uma crise urbana. Petrópolis, RJ: Vozes, 2001.

SEABRA, Odette Carvalho de Lima. Territórios do Uso: Cotidiano e Modo de Vida. In: Cidades. Presidente Prudente, 2004.

SASSEN, Saskia. As cidades na economia mundial. São Paulo: Nobel, 1998.

SCHAPIRA, Marie-France Prévôt. Fragmentación espacial y social: conceptos y realidades. In: "Perfiles Latinoamericanos", n 19, Buenos Aires, 2001.

.Buenos Aires en los años '90: metropolización y desigualdades. In: "Revista Eure", Vol. 28, nº 85. Santiago de Chile, 2002.

SEABRA, Odete, CARVALHO, Mônica e LEITE, José C. Território e Sociedade: Entrevista com Milton Santos, $2^{\circ}$ ed. São Paulo: Editora Fundação Perseu Abramo, 2001.

SEABRA, Odette Carvalho de Lima. Territórios do Uso: Cotidiano e Modo de Vida. In: Cidades: Revista Científica/Grupo de Estudos Urbanos. Presidente Prudente: 2004. SPÓSITO, Maria Encarnação Beltrão. O centro e as formas de expressão da centralidade urbana. In: "Revista de Geografia", vol.10. Presidente Prudente: Unesp.

NOVEMBER, Valérie. "Les territoires du risque: Le risque comme objet de réflexion géographique". Berna: Peter Lang, 2.002.

O'CONNOR, James. "Es posible el capitalismo sostenible?" In: ALIMONDA, Héctor (compilador). "Ecología Política, Naturaleza y Utopía". Buenos Aires: CLACSO, 2.002.

PINTALDI, Silvana Maria. A cidade e a crise. In: DAMIANI, Amélia L., CARLOS, Ana Fani A. e SEABRA, Odette C.de L. O espaço no fim do século: a nova raridade. $2^{\mathrm{a}}$ ed. São Paulo: Contexto,2001. 
REIGOTA, Marcos. "Meio Ambiente e Representação Social". São Paulo:Editora Cortez, 1.995.

. "O que é educação ambiental". São Paulo: Brasiliense, 2.001. (Coleção Primeiros Passos).

SANTANA, Paola V. de. A mercadoria verde: a natureza. In: DAMIANI, Amélia L., CARLOS, Ana Fani A. e SEABRA, Odette C.de L. O espaço no fim do século: a nova raridade. $2^{\mathrm{a}}$ ed. São Paulo: Contexto,2001.

SASSEN, Saskia. As cidades na economia mundial. São Paulo: Nobel, 1998.

SANTOS, Milton. "Por uma outra globalização: do pensamento único à consciência universal". $7^{\circ}$ ed. Rio de Janeiro: Record, 2001.

SPOSITO, Maria Encarnação B. A urbanização da sociedade: reflexões para um debate sobre as novas formas espaciais. In: DAMIANI, Amélia L., CARLOS, Ana Fani A. e SEABRA, Odette C.de L. O espaço no fim do século: a nova raridade. $2^{\mathrm{a}}$ ed. São Paulo: Contexto,2001.

www.granjaviana.com.br (acessado em fevereiro de 2004 e junho de 2006)

www.granjeiros.com.br (acessado em junho de 2006)

www.imolweb.com.br (acessado em junho de 2006)

www.portaldoimovelsp.com.br (acessado em junho de 2006)

www.gpdesurb.com.br (acessado em junho de 2006)

www.wertheimimoveis.com.br (acessado em junho de 2006) 